\title{
Producción horizontal del conocimiento
}

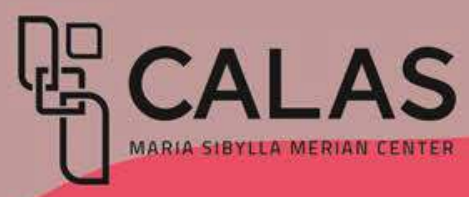



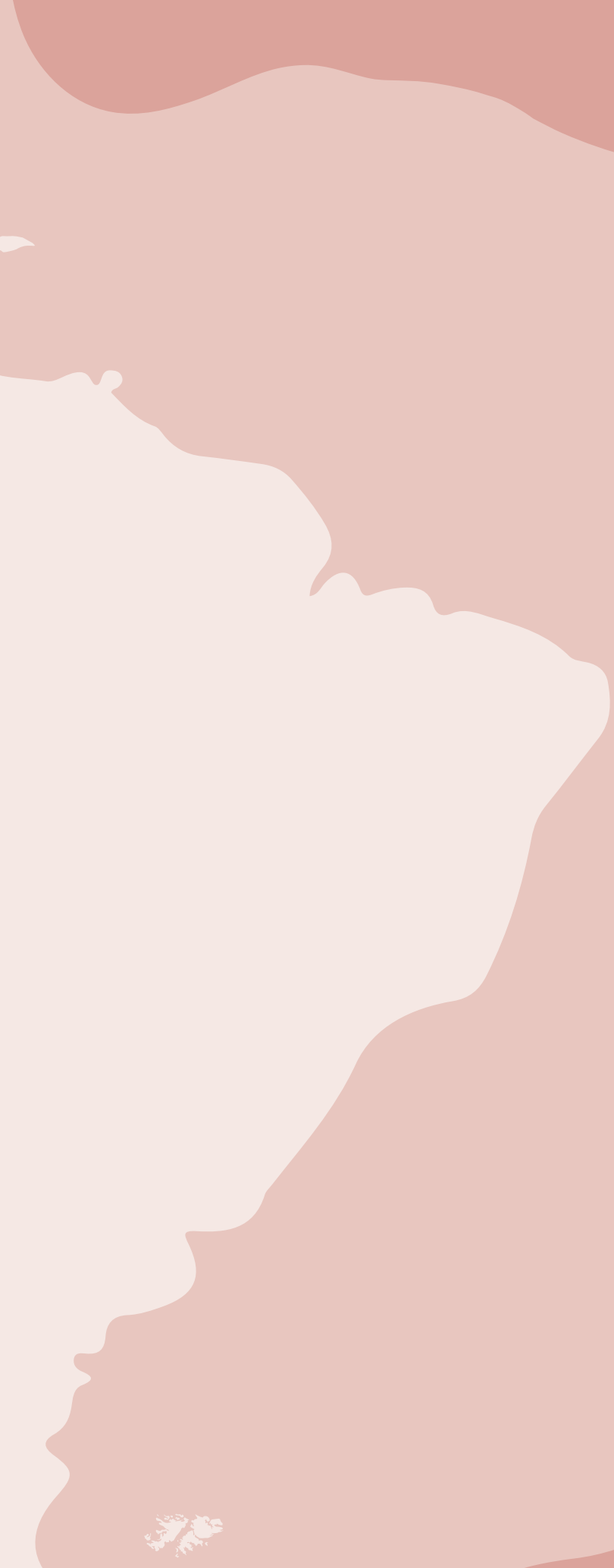


\section{(c) $\underset{\mathrm{BY}}{(\mathrm{T})}$}

Este trabajo está autorizado bajo la licencia Creative Commons Attribution-NoDerivatives 4.0 (BY-ND), lo que significa que el texto puede ser compartido y redistribuido, siempre que el crédito sea otorgado al autor, pero no puede ser mezclado, transformado o construir sobre él. Para más detalles consúltese http://creativecommons. org/licenses/by-nd/4.0/

Para crear una adaptación, traducción o derivado del trabajo original, se necesita un permiso adicional y puede ser adquirido contactando publicaciones@calas.lat

Los términos de la licencia Creative Commons para reuso no aplican para cualquier contenido (como gráficas, figuras, fotos, extractos, etc.) que no sea original de la publicación Open Access y puede ser necesario un permiso adicional del titular de los derechos. La obligación de investigar y aclarar permisos está solamente con el equipo que reuse el material. 
SARAH CORONA BERKIN

\section{Producción \\ horizontal del conocimiento}

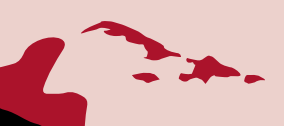




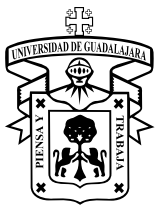

Universidad de Guadalajara

Ricardo Villanueva Lomelí

Rectoría General

Héctor Raúl Solís Gadea

Vicerrectoría Ejecutiva

Guillermo Arturo Gómez Mata

Secretaría General

Juan Manuel Durán Juárez

Rectoría del Centro Universitario

de Ciencias Sociales y Humanidades

Sayri Karp Mitastein

Dirección de la Editorial

Primera edición, 2019

Autora

( ) Sarah Corona de Bak Geler

Published 2020 by

\section{BIELEFELD \\ UNIVERSITY PRESS}

An Imprint of transcript Verlag

http://www.bielefeld-university-press.de

Printed by Majuskel Medienproduktion $\mathrm{GmbH}$, Wetzlar

Print-ISBN 978-3-8376-4974-1

PDF-ISBN 978-3-8394-4974-5

https://doi.org/10.14361/9783839449745

Impreso y hecho en Alemania

Printed and made in Germany

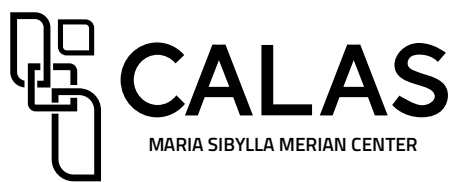

Centro Maria Sibylla Merian

de Estudios Latinoamericanos Avanzados

en Humanidades y Ciencias Sociales

Sarah Corona Berkin

Olaf Kaltmeier

Dirección

Gerardo Gutiérrez Cham

Hans-Jürgen Burchardt

Codirección

Nadine Pollvogt

Coordinación de Publicaciones

www.calas.lat

Gracias al apoyo de

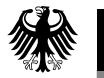

Federal Ministry

of Education

and Research
En colaboración con

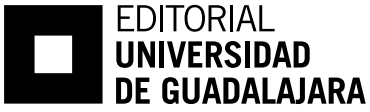

DE GUADALAJARA

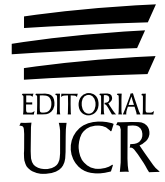

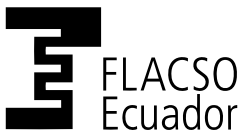

UNSAM

E D I T A 


\section{CALAS. Afrontar las crisis desde América Latina}

Este libro forma parte de los ensayos concebidos desde la investigación interdisciplinaria que se lleva a cabo en el Centro Maria Sibylla Merian de Estudios Latinoamericanos Avanzados en Humanidades y Ciencias Sociales (CALAS), donde tratamos de fomentar el gran reto de analizar aspectos críticos sobre los procesos de cambios sociales. CALAS ha sido concebido como una red afín a la perspectiva de los Centros de Estudios Avanzados establecidos en distintas universidades del mundo y busca consolidarse como núcleo científico que promueve el desarrollo y la difusión de conocimientos sobre América Latina y sus interacciones globales. CALAS funciona en red, la sede principal, ubicada en la Universidad de Guadalajara (México), y las subsedes ubicadas en la Universidad de Costa Rica, Flacso Ecuador y Universidad Nacional de General San Martín en Argentina. Las instituciones latinoamericanas sedes están asociadas con cuatro universidades alemanas: Bielefeld, Kassel, Hannover y Jena; esta asociación fue impulsada por un generoso apoyo del Ministerio Federal de Educación e Investigación en Alemania.

La relevancia de estos libros, enfocados en el análisis de problemas sociales, trasciende linderos académicos. Se trata de aumentar la reflexión crítica sobre los conflictos más acuciantes en América Latina, como una contribución de primer orden para generar diálogos desde múltiples disciplinas y puntos de vista. Más allá de esto, el objetivo de estas publicaciones es buscar caminos para afrontar las múltiples crisis.

Como reconocidos analistas en sus respectivos campos de investigación, los autores nos invitan a ser copartícipes de sus reflexiones y a multiplicar los efectos de sus propuestas, a partir de su lectura.

Sarah Corona Berkin y Olaf Kaltmeier

Directores

Gerardo Gutiérrez Cham y Hans-Jürgen Burchardt Codirectores 


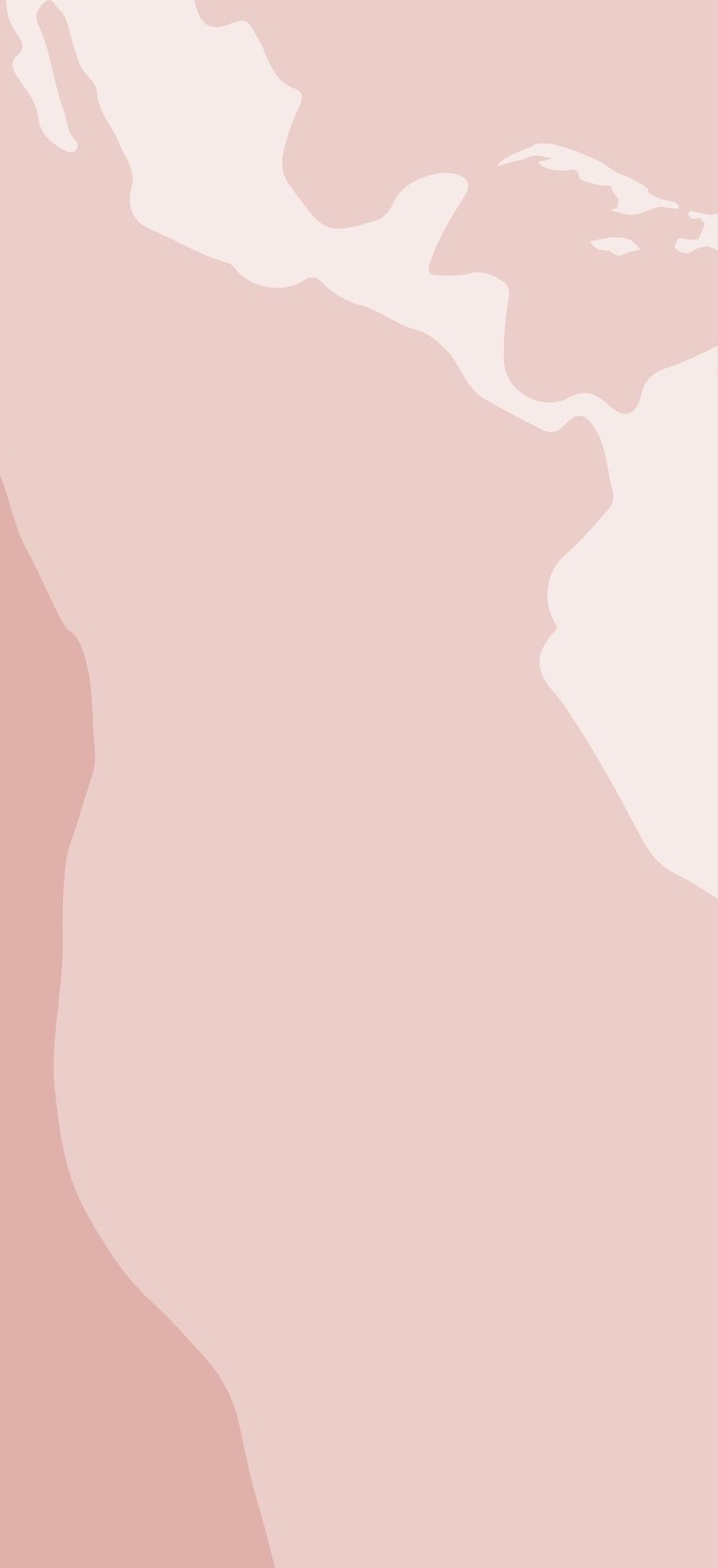




\section{İndice}

Introducción. La producción horizontal del conocimiento

El diálogo para responder a preguntas sociales

Antecedentes de la producción horizontal del conocimiento

Nombrar

Contexto

Los conceptos fundadores

Nombrar la responsabilidad

Reciprocidad

Preguntas

Teoría y marco conceptual

Métodos y procedimientos

Análisis e interpretación

Publicación y crítica

Reproducción 
Epílogo

101

Bibliografía

102

Autora

109 


\section{Agradecimientos}

Colaborar en investigaciones horizontales me ha brindado la oportunidad de conocer diversas maneras de compartir ideas y explorar caminos para mejorar la convivencia entre todos, a pesar de ser tan diferentes, al tiempo de producir nuevo conocimiento social. A mis amigos y compañeros de la Red de Métodos Horizontales mi agradecimiento por ayudarme a entender que lo nuevo se construye en la horizontalidad de los hermanos; especial mención a Carmen de la Peza y a Mario Rufer, de quienes he aprendido mucho en los años que tenemos de trabajar juntos. Agradezco las preguntas de mis colegas y alumnos del Centro Universitario de Ciencias Sociales y Humanidades, de la Universidad de Guadalajara, espero haber respondido algunas de ellas en este libro. A las alumnas que me permitieron acompañar sus tesis donde practicaron la horizontalidad, especialmente a Yazbeth Pulido, Carolina Huerta, Beatriz Nogueira y Daniela Pérez. A Inés Cornejo, profesora de la Universidad Autónoma Metropolitana, Unidad Cuajimalpa, y a Rebeca Pérez Daniel, profesora de la Universidad de Colima, porque a partir de sus aportes a la investigación desde su pertinente mirada regional, nos recuerdan que el conocimiento es siempre contextual. También mi agradecimiento va a Olaf Kaltmeier y a Cornelia Giebeler de la Universidad de Bielefeld en Alemania, y a Maria Rogal de la Universidad de Florida en Estados Unidos, con quienes he trabajado desde tiempo atrás en prácticas horizontales, interculturales e interdisciplinarias de producción de conocimiento. Desde mi arribo a CaLAS, he tenido la suerte de escuchar y alimentarme de la voz de amigos queridos como Jesús Martín-Barbero, Néstor García Canclini y José Manuel Valenzuela, y de nuevas amigas como Claudia Briones y Mara Viveros. Un agradecimiento muy particular a los profesores y alumnos wixaritari de la escuela Tatutsi Maxakwaxi de la sierra norte de Jalisco por su hospitalidad y confianza durante más de veinte años, en los cuales nos hicimos un sin fin de preguntas los unos a los otros. De mi trabajo con ellos hablo en todo el libro. 


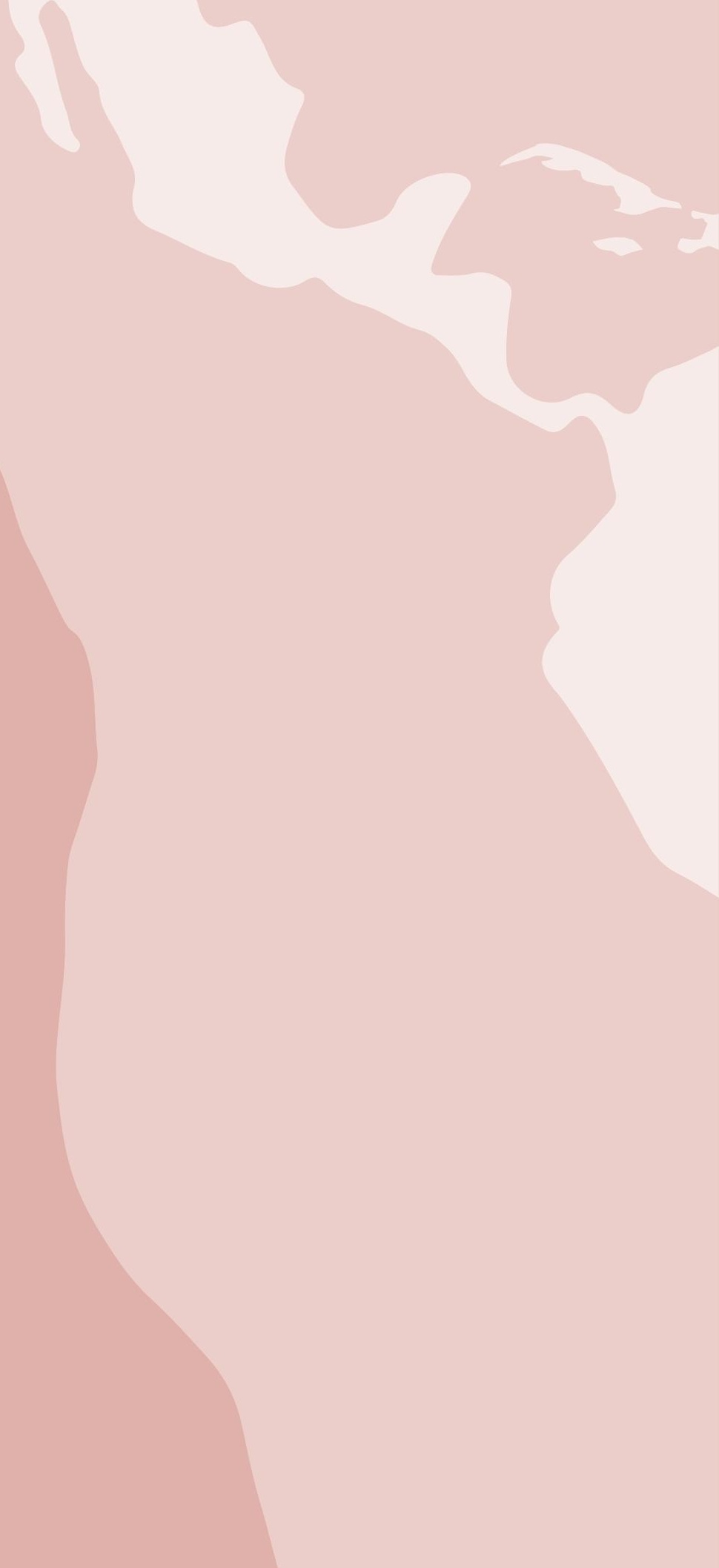




\section{Introducción. La producción horizontal del conocimiento}

La cuestión de fondo de este ensayo puede enunciarse como pregunta: ¿de qué manera podemos generar nuevo conocimiento para afrontar los problemas sociales que hoy nos aquejan? Son muchas las nuevas preguntas que nos hacen pensar que la investigación social con los métodos disciplinares tradicionales está alcanzando sus límites para entender los fenómenos sociales actuales. Mi llamado tiene que ver con conocer desde lo que he nombrado producción horizontal del conocimiento (PHC), es decir, una forma de investigar desde las voces de las distintas disciplinas científicas en diálogo con aquellas no académicas y que pesan de forma diferente en el conocimiento social. En este lugar desarrollo la propuesta de la PHC como la investigación que entabla diálogo con las diversas formas de entender el mundo. Asumir que los implicados en los problemas poseen también soluciones, nos lleva a plantear formas de escuchar, responder y enfrentar en diálogo los problemas que amenazan la vida social. En esta propuesta se exploran las posibilidades de transformar el conocimiento social desde un plano horizontal. Se buscan los mejores recursos políticos e intersubjetivos para transformar la relación entre las personas.

La complejidad de los nuevos problemas sociales pareciera tener pocas respuestas desde nuestro conocimiento académico acerca de la pobreza, la violencia, las emociones y las motivaciones. El saber que hemos acumulado con el tiempo desde la investigación no es suficiente en la actualidad para proponer soluciones políticas económicas y culturales que sean coherentes con la vida de los muchos diferentes que cohabitamos los espacios sociales. Pareciera que las encuestas, las entrevistas 
dirigidas, las observaciones participantes y no participantes, los métodos a partir de la intromisión de modernas tecnologías de vigilancia en los hogares, en fin, el alcance de la ciencia con criterios científicos (CCC) ha sido asolado por un nuevo contexto y hoy esas investigaciones están condenadas a fracasar, enmudecer o repetir el conocimiento construido en otros tiempos y desde otros lugares.

Nos preguntamos, por ejemplo, desde los vaivenes políticos en América Latina, ¿los populismos y las socialdemocracias actuales son de un nuevo tipo donde sólo es central el reparto de dinero a los grupos considerados vulnerables? ¿Qué piensan los que son etiquetados como vulnerables sobre la igualdad y la emancipación? ¿Sabemos cómo se concibe el nuevo colonialismo interno desde la voz de quienes lo padecen? ¿Qué significa para el proyecto de nación que las autodefensas armadas cierren las comunidades y decidan gobernarse al margen del Estado nacional? Los pueblos indígenas, por ejemplo, expresan sus luchas en términos que discrepan de las propuestas críticas hegemónicas, ellos hablan no de un desarrollo alternativo sino de una "alternativa al desarrollo", de la defensa del territorio y de la consulta a la madre tierra.

No sólo en América Latina se observan incógnitas: en Francia se extiende el movimiento de los "chalecos amarillos", sin líderes definidos pero unidos contra el costo de la gasolina y que están en comunicación por redes sociales; también se inconforman con el ostracismo de los pueblos pequeños y aislados de los servicios urbanos, el desempleo, el salario mínimo y las políticas ecológicas, en una lucha que no tiene una clara correspondencia con un partido o una ideología política. ¿Qué entienden por bienestar y por respeto? ¿Por qué siendo votantes tradicionales de la izquierda crecen como grupo hacia la derecha y la ultraderecha?

¿Entendemos las caravanas de migrantes que desde el sur se empecinan en llegar al norte, aun arriesgando sus vidas, o las respuestas de los países receptores? Estamos ante voces múltiples que nos obligan a traducir, pero no serán las políticas internacionales de la interculturalidad, esas que se preocupan más por la estabilidad nacional que por la convivencia armónica de los distintos, las que nos den pistas para superar estas crisis. Para Sartori (2001), la cultura receptora, la sociedad 
y el Estado nacional deben protegerse en primer término. Para Touraine (2006), son el Estado y la sociedad nacional quienes tienen que asegurar la posibilidad de diálogo intercultural. Pero ¿qué piensan quienes migran? ¿Cómo se plantean su vida familiar, como trabajadores, o sus prácticas culturales y ciudadanas en nuevas tierras? En situación de igualdad discursiva, ¿qué negocian y cómo llegan a acuerdos?

\section{El diálogo para responder a preguntas sociales}

Queda claro que surgen nuevos problemas y que las crisis que enfrentamos corresponden al siglo XxI, pero no contamos con suficientes cómos para investigar y responder a las preguntas que se develan en la vida pública. Según Kapuściński $(2009,97)$, "el cometido de observar, examinar, interpretar, y describir la filosofía y la existencia, el pensamiento y las condiciones de vida de tres cuartas partes de la humanidad, sigue -igual que en el siglo XIXen manos de un reducido grupo de especialistas: antropólogos, etnógrafos, viajeros, periodistas [...]". Nuestra propuesta en este libro, desde la PHC, tiene que ver con encontrar las maneras para responder a preguntas sociales a partir de una metodología dispuesta a modificarse contextualmente en cualquier momento. Con base en la práctica dialógica que se entreteje con los múltiples eslabones de saber, que son más vastos que la limitada comprensión occidental del mundo, se busca que en igualdad discursiva afloren las múltiples razones y se produzcan nuevas respuestas.

Partimos de que el conocimiento de los especialistas de la academia no es el único ni siempre el más pertinente. Abogamos por una paridad entre su conocimiento y el que tienen todas las personas. Por ello vale la pena dedicar unas palabras a lo que entendemos por "respuestas dialógicas" a los problemas sociales.

La comunicación dialógica, donde toman turnos el habla y la escucha, define a los seres humanos en tanto que viven en sociedad. Hannah Arendt $(1993,39)$ señala que "la mayor parte de la acción política, hasta 
donde permanece al margen de la violencia, es realizada con palabras". De esta manera la esfera pública, donde los seres humanos se exponen, se muestran y se reconocen frente a los demás, es el lugar idóneo para la construcción de respuestas a las preguntas sociales. En otro texto ya adelantábamos que:

Los conceptos de diálogo son diversos pero un punto de partida para iniciar la discusión puede ser su etimología que se refiere a la interacción de dos o más logos en oposición. Esto implica que en el diálogo participan dos o más sujetos a partir de su propia palabra y su propia razón.

Pero a diferencia de las posturas que consideran que esos sujetos tienen una cultura esencial y estática y que se les puede definir por oposición a otros, consideramos que es necesario repensar el diálogo como el fenómeno social donde los sujetos se construyen permanentemente a partir de las relaciones con otros. [...] Investigar significa entonces promover el encuentro con el otro para alternar las miradas y proporcionar una visión más integral de ambas culturas (Corona y Kaltmeier 2012).

Ahora bien, también existen otros usos del diálogo, como cuando se emplea para conocer las motivaciones y las preferencias de los consumidores para poner la información al servicio del mercado, o para pacificar conflictos sociales pero sin arriesgar el orden hegemónico. Los usos estratégicos del diálogo son antiguos, Villoro pone en relieve cómo los conquistadores han hecho uso de la traducción, del diálogo y de la observación para dominar al otro.

Villoro (2006) señala que la necesidad de comprender la cultura ajena nace de una voluntad de dominarla, y argumenta a partir de tres niveles. El primer nivel en el encuentro con el otro es conjurar su otredad eliminando su diferencia o trasladándola a lo conocido, en ambos casos se borran las propiedades distintas del otro y se le transforma en objeto. El segundo nivel es aceptar su igualdad, pero no su diferencia. En este lugar cabe el ejemplo de Bartolomé de las Casas, que al entender la otredad como mismidad a partir de su principio cristiano "todos los hombres son hijos de Dios", usa la igualdad como derecho abstracto para someter 
al otro sin violencia. El tercer nivel es el reconocimiento de la igualdad y diferencia de todos. Bernardino de Sahagún lo hace con documentos realizados desde las propias voces indígenas, pero el fraile mismo y la Corona española encontraron límites para ese reconocimiento, ya que de reconocerlos, los frailes y el poder colonizador perderían su motivo de existencia. No es casual la prohibición de la obra de Sahagún hasta el siglo XIX.

En la PHC el diálogo con el otro se diferencia de los niveles anteriores y se aleja de la intensión de dominar a favor de la construcción de nuevo conocimiento. En el diálogo de la PHC se puede pensar en un cuarto nivel de conocimiento: buscamos con el otro producir respuestas que aporten a la autonomía y mayor satisfacción para la convivencia de todos.

El riesgo que se toma en el proceso de la comunicación dialógica como se entiende en la PHC -a diferencia de la simple trasmisión o extracción de información- es que la propia cultura cambia con el diálogo. Al participar de un diálogo productivo el discurso propio se transforma, por eso siempre gana en conocimiento y pierde algo. En la PHC, al construir nuevas respuestas producto de la discusión, se busca que los conocimientos de procedencia ganen, pierdan y cambien, y que los sujetos también se transformen.

En torno al diálogo rescato su impulso político. Producir diálogo en igualdad no es encontrar zonas de contacto o lugares de intercambio, ya que desde estas perspectivas la desigualdad en el contacto no se resuelve, la diferencia desde su propia voz no se expone y el aporte de los otros saberes desde la mirada propia no queda claro. En adelante, por diálogo entiendo con Bajtín (2003) la posibilidad de entablar comunicación entre los distintos. En otras palabras, la comunicación se plantea como la capacidad humana donde por turnos el oyente y el hablante conversan, a diferencia del modelo tecnocomunicativo donde un emisor trasmite un mensaje por un canal a un receptor. De esta manera, cuando los oyentes se vuelven hablantes y éstos oyentes, la "conversación" se realiza en otros términos, implica que los interlocutores producen algo diferente, respuestas que se traducen a cada paso, y crean nuevos textos. El intercambio es de un tipo peculiar: se abandonan las respuestas silenciosas y se abren al diálogo horizontal. También se renuncia a encontrar discursos homogéneos, los nuevos textos son compartidos porque son negociados. 
Regresando a las preguntas sobre los problemas sociales, ¿cuáles son los obstáculos metodológicos para crear nuevas respuestas con el otro en lugar de reproducir las mismas opiniones sobre el otro? ¿Cómo hacer justicia a los múltiples conocimientos que responden a su manera a problemas sociales? ¿De qué manera podemos invertir la situación investigativa donde el otro es un objeto situado fuera de la investigación y sólo aparece referido en la enunciación del investigador? Las respuestas a estas preguntas están en las maneras de conocer el mundo social bajo otras condiciones de investigación. En este ensayo propongo ciertas pistas como puntos de partida para la práctica horizontal en los procesos de construcción de conocimiento social. Estas maneras, o cómos de la investigación horizontal, pueden a su vez trasladarse a otros campos que no son los científicos y pueden ayudar a horizontalizar nuestras sociedades que no son del todo democráticas.

\section{Antecedentes de la producción horizontal del conocimiento}

Puede aquí surgir la pregunta ¿la PHC es una forma de intervención en la comunidad como son los métodos colaborativos o participativos? Son varias las fuentes de la PHC. En Latinoamérica en las décadas de 1960-1970, la academia reaccionó a las teorías modernizadoras de Estados Unidos y a sus organismos internacionales sometidos a los intereses del primer mundo, proponiendo nuevos conceptos como praxis social transformadora y visión propia del mundo, con la intención de distanciarse teórica y epistemológicamente de la tradición académica convencional. La teoría de la dependencia que se gestó en el sur latinoamericano piensa su relación con el norte desde el imperialismo cultural, la dominación y la colonialidad, que se leen por primera vez en términos de relación de dominación y no de situación de subdesarrollo.

La teología de la liberación y los movimientos de las radios populares construyen una alternativa a los métodos colaborativos puestos en práctica por los organismos internacionales para el desarrollo y el progreso. Las 
nuevas metodologías tenían que ver con acción popular, con participación en el espacio público y con la disputa por la libertad en contextos de dominación. El pensamiento marxista y su devenir gramsciano, además de la experiencia de la lucha contra las dictaduras militares, aportaron nuevas palabras para pensar hoy los métodos horizontales: hegemonía, lucha por la visión del mundo, ideología dominante y cultura popular.

La relación de la educación y la comunicación (frente al interés funcionalista por la información, los efectos y la recepción) propusieron otras formas de hacer teoría latinoamericana. Los círculos de discusión, las palabras generadoras, actuar sobre la realidad, fueron conceptos que guiaron de forma diferente al maestro y al investigador. La educación popular y la opción alfabetizadora de Paulo Freire fomentaron una ruptura con las prácticas descontextualizadoras que sometían al educando y al investigador. La dignidad, la comunidad y la comunicación-comunión figuraron como conceptos en la investigación en América Latina.

La investigación que realizaban las mujeres en esos mismos años revolucionarios, es prácticamente desconocida. No obstante, su trabajo estableció de maneras diferentes el campo de la investigación en ciencias sociales y culturales. El marxismo, la lingüística francesa y la teoría de la acción, las llevaron a trabajar formas metodológicas que vale la pena destacar. Si bien realizaron análisis textuales y encuestas tradicionales, pronto mudaron a las entrevistas y de allí a la participación política de base, participación en radios populares y prácticas de comunicación popular y para la democratización (Mattelart, Piccini y Mattelart 1970; Mattelart y Piccini 1973; Ribeiro y Barbieri 1973; Mata 1982). Partir de la praxis las llevó a dar contenido a conceptos como educación dialógica y acción política. Este fue el origen de una serie de investigaciones que se destacaron por matizar la "omnipotencia" de la ideología y problematizar el concepto de dominación monolítica. A diferencia de sus colegas que en esos mismos años trabajaban la sociedad desde la economía política, estas mujeres descubrieron que los sujetos con los que trabajaban no eran pasivos ni reproducían "la ideología dominante" de forma homogénea.

Si bien coincido con la investigación realizada a partir de métodos colaborativos y participativos en el interés por participar con el otro, aquí 
se difiere en el objetivo de la investigación y en los métodos para hacerlo. Las propuestas colaborativas bien intencionadas y de mucha ayuda en ciertos proyectos políticos, no alteran en el fondo las asimetrías estructurales que organiza la investigación hegemónica. Partir de los sujetos de la investigación y reconocer la agencia y los discursos de todos, exige una forma distinta de enfrentar el proceso de la investigación.

Los métodos participativos muchas veces reconocen lo que saben otros, sin embargo la investigación se queda en manos del investigador participativo y es finalmente éste quien define los temas importantes, las metodologías, los informes y los resultados. Por su cuenta, la PHC incluye lo que Mouffe $(1999,197)$ llama “indecibles en el diálogo occidental”, en la búsqueda de otras formas de comunicación y producción de conocimiento.

Recientemente los estudios poscoloniales han abierto preguntas en torno a la colonialidad como marca persistente en la modernidad. El estudio de los movimientos sociales de los subalternos que no habían sido considerados en su propia dimensión desde las $\mathrm{CCC}$, implicó pensar en dos modernidades: la de los subalternos y la de los coloniales, de donde se subrayan nuevas maneras de aproximarse a los archivos, descubrir sus prejuicios, sus silencios, y por otro lado rescatar otras fuentes de la historia y la acción política.

En nuestro caso especialmente interesan algunos supuestos desarrollados en torno a la crítica a las "jaulas conceptuales impuestas" por las ciencias sociales en nuestras propias universidades. En esta línea, Lander $(2004,261)$ identifica algunos supuestos básicos del conocimiento eurocéntrico que impactan y dan forma a la única modalidad del conocimiento legitimado como verdadero, universal y objetivo, "con lo cual se define simultáneamente toda otra forma de saber como ignorancia o superstición”. En síntesis, el saber eurocéntrico se basa en la conjetura que la ciencia europea es universal y punto máximo del avance de la humanidad. El conocimiento del otro termina por servir para distinguir a los europeos como superiores y a los no europeos como inferiores.

Boaventura de Sousa (2010) agrega a la discusión poscolonial su concepto epistemicidio, con el cual deja ver el colonialismo en la cultura y el conocimiento. El hecho de que el colonialismo en su forma original 
haya llegado a su fin no significa que el colonialismo sobre el saber no se siga reproduciendo. En nuestras universidades latinoamericanas aún se enseña que se puede pensar en las propias culturas y mejores formas de convivencia social a partir de investigaciones con herramientas analíticas del occidente eurocéntrico. Nos preguntamos, ¿será posible conocer lo que los otros saben con develaciones semióticas, con encuestas unidireccionales o conceptos de las $\mathrm{CCC}$, lejanos a las realidades económicas, políticas y culturales propias? Ante la dificultad para imaginar mejores formas de vivir, De Sousa propone crear distancia teórica y epistemológica con la tradición occidental que fue creada a partir de las necesidades de dominación capitalista y colonial, diferenciando los saberes visibilizados y útiles de los invisibles, olvidados y considerados inútiles o peligrosos.

Las diferentes propuestas decoloniales nos ayudan a comprender que estamos obligados a distanciarnos frente al autoritarismo de la CCC. Entender de otra forma la exclusión de conocimientos causada por el colonialismo eurocéntrico y el colonialismo interno de nuestros países, nos aproxima a otras preguntas y a comprender, en palabras de Rufer (2016, 165), el "juego que se produce entre los saberes y los poderes, entre las disciplinas y los mecanismos de institucionalización”.

Ante la multitud de qués sin respuestas y del silencio ante las preguntas procedentes de las transformaciones sociales actuales, en este libro nos centraremos en los cómos de la producción científica, al coincidir con Jesús Martín $(1980,101)$ en que:

la dependencia no consiste en asumir teorías producidas "fuera"; lo dependiente es la concepción misma de la ciencia, del trabajo científico y su función en la sociedad. [...] lo grave es que sean exógenos no los productos sino las estructuras mismas de producción.

Consideramos que son múltiples las fuentes de conocimiento que participando de forma horizontal construyen otras respuestas a las preguntas sociales. Sabemos que las distintas experiencias sociales del lenguaje pueden atraer otros procedimientos de acceso, una nueva producción de conocimiento; la diversidad de voces "genera textos que pueden 
ser muy diversos: pueden ser textos formalmente llamados libros o artículos, cuentos, crónicas, ensayos; y pueden ser también los grafitis, las conversaciones coloquiales en un metro, las etiquetas de los vinos, etc." (García cit. en Greeley 2018, 219). Las voces indígenas, campesinas, de los artistas y músicos, nos han hecho entender las épocas, los contextos y la lucha por pensar el mundo desde otro lugar. La opción por el diálogo y las múltiples formas de expresión dejan huellas en nuestro trabajo horizontal. De la misma manera, las reflexiones sobre el género, la raza y la clase social impactan los resultados de la PHC.

\section{Posición teórica en clave de género}

Además de la raza, la ciencia colonial y moderna también se constituye con base en la asimetría entre los géneros, teniendo al sujeto masculino como universal. En este sentido, la ciencia moderna es colonial y masculina y está anclada en los siguientes binarismos: occidental/indígena, universal/local, masculino/femenino.

[...]

Podríamos ampliar la cuestión de la representación y de la decolonización, más allá de las divergencias en las miradas debido a cuestiones culturales, a cuestiones de género. Actualmente, el problema de la representación es también una preocupación de las feministas decoloniales, que proponen una perspectiva de las relaciones de poder en donde las jerarquías no son esenciales y hay un complejo cruce entre género, raza, clase, sexualidad y pertenencia geográfica.

Mi propuesta es que podríamos ampliar la cuestión de la representación de unos y de otros, de investigadoras e investigadas -hacia donde todos los participantes tengan la autonomía de la propia voz y de la propia mirada- a las cuestiones de género. Es decir, los puntos de vista de los participantes en las investigaciones no sólo divergen en términos culturales como también en términos de género (Nogueira 2019).

Otra fuente central de la PHC es la filosofía del lenguaje cuando partimos de que el papel del lenguaje es mediador del conocimiento y 
que no hay vía directa de acceso a la realidad, la cual está mediada por el pensamiento y éste por el lenguaje. Aunque creemos que vemos, sentimos o escuchamos directamente, lo que en realidad percibimos son imágenes discontinuas que nuestro lenguaje ordena y les otorga significación. Son las palabras las que nos permiten entender el mundo de una u otra manera. Hablar-pensar se impone de forma dictatorial, según dice Foucault, y es contra esa dictadura de un solo lenguaje que define lo que es conocimiento y lo que no es, que nos proponemos escuchar otras palabras y en diálogo con otros, formular nuevas aproximaciones al conocimiento y a las preguntas sociales que nos incumben a todos.

El eje que guía este planteamiento es conocer con el otro para encontrar mejores formas de vivir juntos a partir de la expresión de la diversidad en términos de igualdad. Quizás al lector, en una primera impresión, puede parecerle que la PHC es un mal uso del "método científico" - no se habla aquí de objetividad, de la verdad o la representatividad-, pero si se observa más de cerca, se puede ver que la PHC es otra forma de investigar, con otra gramática, con la que todos pueden hablar y decir diferentes cosas y de diversas maneras.

Lo que sigue tiene como objetivo señalar algunas precauciones para realizar la PHC. Si bien aquí no se trata de proporcionar recetas para investigar horizontalmente, renunciar del todo a orientar la propuesta podría dejar el camino libre para que se reproduzcan las lógicas naturalizadas de las CCC, permitiendo que se excluya a los que quieren ser escuchados y que en muchas investigaciones son ausentes desde sus propias voces. Siempre en igualdad discursiva y sin la condescendencia que puede manifestarse cuando se pretende dar la voz al otro, buscamos investigar en igualdad con todas las voces que respondan a una pregunta social. De esto quiero hablar en el resto del libro a partir del lenguaje para nombrar, para ordenar y para transformar el conocimiento social desde la PHC.

Este ensayo está organizado en tres capítulos que exponen los tres temas relacionados con la PHC. El primero, titulado "Nombrar", busca ubicar la propuesta de la horizontalidad en el proceso de la investigación en ciencias sociales y culturales en la reflexión dialógica, la cual se fundamenta en que pensar con otros sólo es posible con el lenguaje, que lo 
que existen son las palabras para nombrar y que el conocimiento se nutre cuando varios lenguajes comparten un objeto de investigación y juntos construyen nuevo entendimiento. Encontramos la diversidad de lenguajes en las distintas disciplinas científicas y también en el conocimiento que se tiene fuera de la academia. Es la diversidad de formas de conceptualizar el mundo lo que nos permite profundizar en el conocimiento social, y es nuestra responsabilidad identificar las formas en que los diferentes que todos somos, nombramos y pensamos el conocimiento valioso.

El segundo capítulo, "Ordenar", se acerca a lo que podemos llamar un recetario con pistas que el usuario horizontal pueda aplicar. Los conceptos y categorías aquí sugeridos no son reglas sino recomendaciones para crear nuevas formas de investigar. Se discuten los conceptos eje que atraviesan todos los pasos de la PHC, que son: el conflicto generador, la igualdad discursiva y la autonomía de la propia mirada. Al modificar el fondo de las categorías convencionales de las CCC, se proponen otras formas de interrogar al hecho social.

En el tercer capítulo, “Transformar”, se observan ciertas trampas en las ciencias sociales y culturales basadas en los criterios de las CCC. La validación en nuestro entender incluye no sólo los resultados de las investigaciones, sino los conceptos mismos que se usan para legitimarlos. La PHC parte de que el conocimiento es valioso cuando construido entre varios saberes, de forma interdisciplinaria e intersubjetiva y en diálogo, logra entender los fragmentos de la realidad imposibles de acceder con una sola visión del mundo. Transformar el conocimiento, construir un tercer texto con la participación horizontal de todas las voces, es la forma de validar la PHC.

Este libro también contiene una serie de textos independientes identificables por los recuadros intercalados entre las páginas. Los autores de estos escritos son investigadores que llevan a cabo su trabajo con la sociedad. Los fragmentos elegidos son pequeñas muestras de cómo cada uno enfrentó algún segmento de la PHC; espero que nuestras historias motiven al lector a optar por horizontalizar la investigación que realiza. 


\section{Nombrar}

En este capítulo pretendo identificar el lugar del lenguaje, la comunicación y el diálogo en la PHC. Sostengo que la construcción horizontal del conocimiento se caracteriza por la búsqueda de conceptos novedosos que permitan entender nuevas realidades. Conceptos como interculturalidad o ciencia democrática muchas veces tienen sus referentes en las prácticas "normalizadas" de la investigación CCC, donde hay poco espacio para exponer el conocimiento propio de quienes externos a las universidades, también construyen cotidianamente conocimiento. Aunque excluido o no siempre consciente en los actores mismos, su conocimiento y sus conceptos pueden ser constructores en horizontalidad de nuevo y valioso saber social.

Para iniciar propongo la hipótesis siguiente: en América Latina vivimos una crisis epistemológica en la medida en que los viejos conceptos no nos sirven para explicar las nuevas realidades. Retomo la noción de tendencias conceptuales subterráneas como aquellas que nos impiden comprender y explicar las realidades latinoamericanas contemporáneas. Saskia Sassen (2015) cuestiona las tendencias conceptuales subterráneas, como llama ella a las categorías que permiten conocer nuestras economías, nuestras sociedades y nuestra interacción con el entorno. Para Sassen, esos conceptos subterráneos son maneras que utilizamos para organizar nuestro pensamiento y son precisamente los que tenemos que cambiar si queremos producir nuevo conocimiento.

El control de los métodos y los resultados de la ciencia con criterios científicos hegemónicos, genera resultados que no sólo no actualizan el conocimiento, sino que no responden a los nuevos y viejos problemas 
que nos aquejan. De acuerdo con esta autora, una de las trampas de la endogeneidad es crear una explicación del fenómeno X que a la vez impide ver la no-X (Sassen 2010). En otras palabras, por repetición ciertos conceptos han llegado a nombrar el mundo y todo aquello que no se encasille en esas etiquetas o tendencias conceptuales subterráneas, permanece oculto, invisible e irreconocible.

La existencia de múltiples lenguas nos ha mostrado de sobra que existe igual número de realidades que tienen sus propios problemas, formas de entenderlos y resolverlos, sin embargo, se sigue pensando en esta diversidad como un castigo y en la ciencia occidental como constructora de una única salida universal. Las políticas interculturales muchas veces reclaman el derecho de todos, pero no dejan de considerar a la diversidad como un problema que debe ser solucionado. Por el contrario, Bolívar Echeverría (1997) no ve en el mito de la Torre de Babel un problema, sino más bien lo considera como una aportación al conocimiento, porque las lenguas al tener diferentes maneras de comprender el mundo constituyen la riqueza de lo humano, la capacidad de multiplicar las soluciones y las respuestas a los problemas. En esta misma línea, pensamos que la pluralidad de lenguas y con ellas sus maneras de identificar el mundo, deben ser acopiadas y puestas en diálogo por las ciencias sociales si queremos construir conocimiento para vivir mejor en sociedad.

Se ha desaprovechado la posibilidad de que las ciencias sociales incluyan esas voces que poseen otras palabras para pensar y con ellas enriquecer nuestro conocimiento. Lamentablemente se ha frustrado la esperanza en la CCC como salida a los problemas sociales que nos afectan. Como afirma De Sousa (2017) con respecto al lenguaje de las ciencias: estamos en una crisis de pensamiento porque tenemos un límite de lo que podemos pensar.

Un cambio se produce cuando se transforma la tendencia conceptual subterránea. De conceptos naturalizados formulados por voces occidentales que excluyen los conceptos que no son suyos, no emerge el nuevo conocimiento que requieren las ciencias sociales. Según la PHC, ese conocimiento que se produce entre las diversas visiones de la realidad no significa que sea novedoso o más "avanzado", sino que es el 
conocimiento que permite caminar de otra manera, para encontrar respuestas diferentes a la convivencia entre todos los diversos que somos.

Ahora bien, los nuevos aportes científicos se procesan no por la teorización convencional, pues es allí donde conceptos, métodos y resultados se reproducen. Sassen propone ir hacia abajo, hasta sus elementos más básicos en un esfuerzo por desteorizarlos. En otras palabras, ir hacia abajo para crear nuevo conocimiento significa reconocer que cada palabra tiene su contexto, su argumento, su razonamiento, sus logos. Para que la conceptualización no sea una nueva camisa de fuerza, la investigación debe ser un acto donde las teorías que se construyen sean producto de los saberes de múltiples disciplinas y grupos sociales y sus contextos, y que sirvan para responder a las grandes preocupaciones sociales.

El desinterés por el vínculo entre el conocimiento y el contexto es consecuencia de la institucionalidad académica que poco hace por abrir las puertas a la pluralidad del pensar y hacer, lo que ha impedido convocar a todas las voces que producen conocimiento. Construyendo conceptos que alteren las tendencias conceptuales subterráneas, se puede superar el proyecto occidental de conmensurabilidad universal, para que, en su lugar, todas las voces y sus razones sean convocadas a pensar con nuevos conceptos.

\section{Contexto}

En el modelo de la comunicación de Jakobson, uno de los seis factores inalienables que permiten la comunicación es el contexto. Sin embargo, el autor no le dedica mucha atención al concepto y su definición es ambigua, identificándola con el "referente" o aquello sobre lo que el emisor refiere durante la comunicación. Por otro lado, según la etimología, contexto viene de cun (con) y textus (texto): trama de un tejido o una obra. De esta manera, se acerca mejor a lo que queremos significar con contextualizar la construcción del conocimiento en la PHC. El contexto no será un referente externo sino el elemento interno en la construcción misma de la expresión. 
Contra la lingüística tradicional y los conceptos de lengua y habla, Bajtín presenta el lenguaje como un proceso vivo. Para él, los géneros discursivos mandatan el aprendizaje del lenguaje y son éstos los que nos permiten comunicarnos porque parten del conocimiento social del lenguaje. Tal como se puede apreciar, el enunciado remite a sus condiciones de producción: no es individual y se genera desde un colectivo social. Como consecuencia, el lenguaje, según Bajtín, conlleva siempre un contexto que pone en juego múltiples enunciados que como eslabones conforman la cadena comunicativa.

El sujeto debe ser comprendido como constitutivamente dialógico y lo social abordado como un proceso polifónico, en diálogo, nunca acabado, siempre en construcción de nuevos eslabones. Con relación al contexto, la significación del enunciado sólo cobra existencia en su relación con las circunstancias concretas de enunciación, y estas circunstancias no son simplemente referidas al sistema lingüístico, sino que son parte del contexto sociohistórico y material en el cual la comunicación se lleva a cabo: "Cada enunciado separado es, por supuesto, individual, pero cada esfera del uso de la lengua elabora sus tipos relativamente estables de enunciados a los que denominamos géneros discursivos" (Bajtín 2003, 248).

Bajtín considera el discurso como un terreno de constante lucha entre las fuerzas que lo orientan hacia la sistematización, estructuración social y domesticación, y aquellas que constantemente lo impulsan a la diversidad, novedad e impredecibilidad. Las que se orientan a la estructuración permiten la comunicación convencional, pero las otras pugnan por la desestructuración, dando movimiento y dinamismo a lo social, orientándolo constantemente a la no sistematización en pos de lo nuevo y diverso.

Por otro lado, filósofos como Rorty y Fornet-Betancourt (Oliveira 2013) coinciden en abandonar la universalidad del conocimiento, para adoptar una actitud contextual. Para los autores, la contextualización de la razón es una forma de resistencia al colonialismo epistémico. Cada contexto nos permite comprender los logos que surgen de la comunidad de hablantes en contacto con otras culturas y ambientes.

Reconocer nuestras contingencias, es decir, la producción de conocimiento desde nuestro contexto, depende del lenguaje. Para poder 
desmitificar la razón única y cuestionar la racionalidad eurocéntrica, es necesario transformar nuestra postura y explorar la existencia de la diversidad de los lenguajes y sus múltiples razones.

Los estudios culturales, de acuerdo con Grossberg, tienen en su fundamento la reflexión sobre el contexto o la coyuntura. Dicho autor, desde su "contextualismo radical", permite ver fenómenos estructurados según prácticas discursivas y no discursivas, en contextos políticos y económicos de la vida cotidiana. De esta manera, "la contextualidad radical de los estudios culturales también reconfigura su relación con la teoría. [Sin embargo,] si bien los estudios culturales están comprometidos con la necesidad del trabajo teórico, consideran la teoría como un recurso que debe ser usado de manera estratégica para responder a un proyecto particular, cuestiones y contextos específicos" (Grossberg 2009, 34). El problema de pensar con la misma teoría y, por lo tanto, la repetición de lo ya dicho y hecho, frente a la posibilidad de una construcción nueva de conocimiento no podría ser mejor expresado: "la teoría se convierte en una manera de evitar los riesgos de la investigación. Al definir por anticipado las preguntas y las respuestas, las apuestas teóricas a menudo reducen la posibilidad misma de contar una historia distinta y mejor, una historia de sorpresa y descubrimiento" (Ibid., 35).

Nuestra propuesta coincide con la necesidad de emplear y reconfigurar la teoría en el contexto del trabajo de la investigación, pero discrepa con su principio de "uso estratégico" de las teorías vigentes, o sea, el uso que algunos estudios culturales hacen de ellas y que define las preguntas que realiza el investigador al enfrentarse al trabajo empírico. En la PHC consideramos que no se trata de conectar las teorías a lo específico de un momento dado, sino que los investigadores que participan en crear el nuevo conocimiento, las poseen definidos por su contexto.

Ahora bien, ¿qué es lo enunciable en una época dada, en un entorno determinado? ¿De qué manera el contexto define lo decible y lo pensable? Con Foucault podemos continuar con la reflexión de la contextualización para modificar la suposición de la existencia de una sola racionalidad eurocéntrica. Según el autor, el dilema de cómo articular el contexto discursivo de las prácticas discursivas con los procedimientos 
de exclusión, se resuelve con el concepto de dispositivo. Por dispositivo se entiende un entramado de prácticas discursivas y no discursivas que delimitan lo que puede decirse y lo que no, el lenguaje y su uso modificado por los procedimientos sociales de exclusión.

Foucault destaca los procedimientos externos e internos que prohíben, excluyen y seleccionan el discurso, además de que "conjuran el azar" o, dicho de otra manera, controlan la posibilidad de salir de lo decible y pensable por una sociedad determinada. El lenguaje y el logos se aprende en una cultura a partir de las instituciones que lo enseñan y perpetúan de maneras diversas. Los dispositivos se conforman de materialidades heterogéneas: discursos, prácticas burocráticas, datos estadísticos, gestos y movimientos corporales, que condicionan el conjunto de las relaciones de fuerza y son construidas por las mismas. El dispositivo no es algo abstracto, es una red de relaciones situada espacial y temporalmente. En otras palabras, es el contexto que define lo que hacemos, pensamos y decimos.

Nuestro trabajo no es disciplinario de fronteras rígidas, ni tampoco uno interdisciplinario donde se suman y yuxtaponen apuestas teórico-metodológicas dispares. En un intento por incorporar las voces y miradas (ajenas y propias) he ido desplazando algunos conceptos convencionales de las ciencias sociales, para construir una dinámica que permita responder ¿cómo incorporar las miradas del investigador y el investigado para conocer desde los contextos y el diálogo?

\section{Los conceptos fundadores}

Las categorías con las que trabajo delimitan necesariamente lo que me es visible, dan un orden a mi actividad y provienen de la teoría occidental. $\mathrm{Mi}$ experiencia de más de 20 años con el pueblo wixárika ${ }^{1}$ me ha enseñado que

Los wixaritari (wixárika en su forma singular) son uno de los 64 pueblos indígenas que habitan en México. Su lengua materna pertenece a la familia yutoazteca; en 1985 se inició la forma actual de escribir su lengua. El 15.5\% son monolingües en wixárika. Habitan en el norte del estado de Jalisco, zonas de Nayarit y Durango, y están organizados en 3 comunidades (San Sebastián, Santa Catarina y San Andrés) en un territorio 
no hay esencias indígenas para rescatar, que asumirse como metadefensora de los indígenas o "hablar por los subalternos" es precisamente la forma de fomentar los estereotipos. Su lengua y sus conceptos para conocer el mundo social ponen en cuestión los nuestros y confrontan el saber occidental con sus propios conceptos, estrategias de comunicación y política. Construir categorías juntos para penetrar y transformar los conceptos eurocéntricos que excluyen el diálogo, nos permite construir conocimiento con los otros. En este intercambio he identificado tres ejes que atraviesan el trabajo horizontal y que están presentes a cada paso en el proceso de PHC: el conflicto generador, la igualdad discursiva y la autonomía de la propia mirada.

\section{Conflicto generador}

Las preguntas de Rushdie no podían ser aquí más apropiadas: “cómo llega al mundo lo nuevo? ¿Cómo nace? ¿De qué fusiones, transubstanciaciones y conjunciones se forma? ¿Cómo sobrevive, siendo como es tan extremo y peligroso? ¿Qué compromisos, qué pactos, qué traiciones a su íntima naturaleza tiene que hacer para contener a la pandilla de demoledores, al ángel exterminador, a la guillotina? ¿Es siempre caída el nacimiento?". El poeta parece decir que lo nuevo surge de un proceso complejo y conflictivo, donde para existir se gana y también se pierde. La PHC implica ese mismo dilema porque el diálogo es inicialmente conflictivo, es un encuentro en la intersección de diferentes puntos de vista y miradas del mundo; más aún cuando la tarea implica el encuentro entre perspectivas muy diferentes, como aquellos de distintas disciplinas o con las voces externas a la investigación académica.

En la PHC optamos por el conflicto como condición generadora: los discursos distintos se exponen uno frente a otro y se prestan para construir algo nuevo. De esta manera, la práctica de la investigación

de $4100 \mathrm{~km}^{2}$, de los $90000 \mathrm{~km}^{2}$ que reclaman como tierras propias. El 3\% son tierras de cultivo, el $44 \%$ pastizales y el $52 \%$ boscoso. La primera carretera de terracería que comunica la comunidad con la cabecera municipal fue inaugurada en 1998 y se instaló la electricidad en 2009. Se rigen con un doble sistema político: el que responde a las autoridades tradicionales y el que responde a las leyes estatales y federales mexicanas. 
transforma las relaciones sociales y los lenguajes con los que se identifica el mundo, y así genera nuevo conocimiento. El resultado del conflicto generador son diálogos "profundamente productivos, están preñados de nuevas cosmovisiones potenciales, nuevas formas de percibir el mundo" (Bajtín cit. en Bhabha 2003, 103). El conflicto generador también se entiende desde otros lugares de la producción científica. Walter Gilbert, Premio Nobel de Biología Molecular, argumenta que el progreso científico nace del embate de las ideas opuestas:

La gran lección de la historia es que el conocimiento se desarrolla a partir del conflicto de puntos de vista, que una visión consensuada generalmente atrofia, porque no permite ver los problemas de ese consenso [...]. Esta es la base de la teoría democrática, es una de las razones por las que creemos en la libertad de pensamiento; y es una de las grandes fuerzas en términos de desarrollo intelectual (Gilbert cit. en Epstein 1996, 130).

El sentido del diálogo que aquí se considera, más que acercar a dos posturas distintas para que se conozcan y se entiendan o lleguen a un consenso, se refiere al hecho de aceptar el estado de la investigación compartida para producir un estudio diferente, híbrido y subversivo, una nueva investigación al servicio de la interpretación horizontal del mundo social. Bolívar Echeverría reconoce una identidad evanescente, un estado de productividad social donde los diversos involucrados ponen en pausa su identidad para escuchar al otro y juntos crear algo nuevo. En el libro Ver con los otros, con Jesús Martín Barbero, aclaramos que la meta no es escuchar más para interpretar mejor al otro, "ni siquiera de pasar al otro lado por un momento y regresar al de origen sin ser tocado; tampoco se trata de 'convertirme en uno de ellos'" (Martín y Corona $2017,140)$. Si el nuevo conocimiento no transforma el lenguaje y la manera de ver del investigador, su conocimiento no deja de ser iterativo.

La investigación cuando dialoga significados, no arroja una investigación dominada por la reproducción siempre igual de resultados previsibles. En el diálogo se practica el extrañamiento a la norma autorizada y 
se produce un "tercer texto" entre los participantes en el proceso. El conflicto generador articula de forma diferente el componente "propio" del encuentro original, porque la horizontalidad se opone a los binarismos comunes, como son investigador/investigado, legítimo/ilegítimo, moderno/antiguo y ciencia/saber, que excluyen de la investigación el nuevo conocimiento. El producto es nuevo, se compone de lo propio y de los otros, y construye visiones que son diferentes y se resisten a la réplica de resultados realizados con teorías y técnicas uniformes.

El conflicto generador tiene que ver con no ocultar o anular las formas y saberes propios, para conocerse en el diálogo con el otro, ejercitar la igualdad a pesar de la diferencia, poner a prueba el vínculo horizontal y permitir que se expresen las propias necesidades y las ajenas, se enfrenten las disputas y se encuentren formas nuevas y negociadas de vivir juntos. El poder puede ser desigual y el componente hegemónico ser más fuerte, pero al articularlos de forma distinta podemos observar las visiones propias, históricamente nuevas, que sin rechazar completamente el ingrediente hegemónico tampoco lo aceptan de idéntica manera, y así surge algo diferente y nuevo.

Si el papel del otro se desvaloriza y se le considera oyente neutral o investigado pasivo, tenemos un proceso incompleto del proceso multidiscursivo de la comunicación. El lugar que se reconoce a cada uno de los interlocutores de la comunicación definirá el potencial del diálogo y la capacidad de crear nuevo conocimiento.

Para que el conflicto generador sea productivo, se valora la relación sobre la comparación, porque cuando se acude al uso de la comparación de conocimientos generalmente el investigador hegemónico impone la superioridad de sus saberes e impide ver el alcance de los conocimientos de los otros. Peor aún, en la comparación el investigador se pone al servicio del orden social, creyendo que sabe más, silencia y desaprovecha la oportunidad de sumar al conocimiento. Anular por comparación los saberes del otro desde su propia voz, destruye la posibilidad de crear conocimiento dialógico.

La generación de nuevo conocimiento deja caer ciertas certezas hasta entonces construidas, pero a cambio se hacen posibles los nuevos en- 
tendimientos. En diálogo con los investigadores wixaritari he podido concebir que a diferencia de la investigación CCC, donde a los investigadores se les recomienda ocultar sus intenciones, actuar como ingenuos, en fin, usar tácticas agresivas y engañar a los sujetos como condición para descubrir "la verdad", es la transparencia de sus intenciones, es decir, la horizontalidad de su práctica la que puede descubrir nuevo conocimiento.

Por otro lado, el conflicto generador no tiene recelo para intervenir en una comunidad, considerada universo normado y estático por los investigadores acostumbrados a buscar la pureza, la objetividad y la neutralidad. Estos investigadores sienten la necesidad de justificar su intervención bajo la supuesta o real demanda de ayuda por parte de las comunidades. Muchos estudios colaborativos se justifican con las solicitudes de las comunidades en torno al apoyo en educación, salud, contaminación ambiental, desarrollo económico y otras. Para estos investigadores, la demanda pareciera mitigar y disculpar la violencia de la intervención, a la cual temen por considerar que se contamina la pureza de sus culturas originales. La comunidad wixárika difiere en este sentido, puesto que considera que de la misma manera que los no indígenas transforman su cultura, la propia también está históricamente situada.

La demanda y la solicitud de colaboración pueden encubrir la intervención y terminan construyendo jerarquías en las relaciones: uno sabe, el otro no sabe. Aun en las investigaciones en que se exploran "problemas conjuntos con la comunidad", el mismo punto de partida -la demanda- aniquila la igualdad de los interlocutores.

Existe otro tipo de estudios de la CCC donde no hay una demanda explícita y el investigador se ve confrontado con el problema para explicar éticamente su actividad. En estos casos, el informe de investigación o la tesis dicen cumplir con una supuesta demanda con interpretaciones y soluciones a los problemas observados. Aunque ahora muchos antropólogos y científicos sociales son cuidadosos con "sus comunidades" durante su trabajo de campo, la investigación misma sólo ratifica la asimetría de la intervención. En este tipo de intervención, las categorías, las identidades de los participantes y el destino mismo de la intervención ya están integrados a los mecanismos oficiales que definen la situación 
científica. El hecho mismo de construir un objeto de estudio considerado "adecuado" con una teoría "correcta" para una disciplina dada, delimita y excluye lo que no está contemplado por ella. El estudio al ubicarse dentro de una teoría para que sea "un buen objeto de conocimiento" forzosamente reproduce una relación de dominación. A su vez, cada disciplina tiene sus "buenos objetos de investigación", que dificultan desde la academia el diálogo interdisciplinario y la participación de las múltiples voces de los implicados en los problemas sociales.

Encontramos también críticos radicales de la intervención en las comunidades consideradas por ellos intactas; pero en su afán de proteger su pureza, cierran las puertas no sólo a la investigación, sino a la posibilidad misma de ejercer el diálogo y la igualdad discursiva. Si se piensa que sólo hay dos caminos con la intervención, los cuales son que el investigador intente volverse un miembro de la comunidad para "dar voz" a los vulnerables o, por otro lado, que se dé el recrudecimiento de la identidad del investigador y la afirmación de sus normas de investigación y de su saber propio, entonces sólo se alcanza a imaginar una investigación que confirma el orden establecido y niega el conflicto generador y la posibilidad de construir nuevo conocimiento.

La paradoja de la CCC es que por un lado se erige como único saber legítimo sobre el otro y limita el conocimiento al derivado de una receta para reproducir el poder académico; por otro lado, protege al otro de las investigaciones que llama "intervenciones" porque se considera que contaminan un universo puro y único. De esta manera, la CCC reproduce sólo la voz desde el micrófono hegemónico. Cuando el conocimiento del otro no se escucha como desea ser escuchado, no hay oportunidad de fundar un conflicto generador que produzca relación, ni poner a prueba la igualdad discursiva o la autonomía de la propia voz.

Mi posición frente a la intervención es distinta. Primeramente, el universo de las comunidades no es originario con historias y rituales puros e inalterados. Desde esta perspectiva, las culturas no están definidas de una vez por todas. Sus historias están siempre en movimiento, son contradictorias en ciertos momentos y son dinámicas. Más allá de celebrar la diversidad, intento, a partir de mi intervención como conflic- 
to generador, construir oportunidades de igualdad discursiva para que cada quien se exhiba como desea hacerlo.

\section{Las lenguas propias y ajenas}

Cuando aprendan muchas letras y sepan mucho, tienen que ver por su tradición. Ustedes alumnos son como nuevos, son el futuro, deben estar atentos para que su cultura no se debilite. El vestuario no es una prioridad; no es importante que un muchacho que se ha preparado use vestido occidental. La espiritualidad es lo esencial [...]. Aunque se vayan a la ciudad, aunque se vistan de occidentales, adentro del cuerpo siempre sean huicholes. [...] Tenemos que prepararnos, poseer dos armas: el conocimiento de la cultura propia y la de los otros. Como wixaritari es necesario conocer y cuidar nuestra propia cultura para no perderla, pero también conocer las otras que existen para que el día de mañana podamos distinguir y defender lo nuestro. Hay que comprender la otra lengua, primero conocer la propia y también aprender la de los otros. Saber la otra lengua para defender nuestra cultura y nuestra tradición. Sepan que si no se preparan, la cultura va a desaparecer (Salvador y Corona 2018).

Hay otra forma de aproximarse al otro y es la que he buscado explorar en los últimos años con el pueblo wixárika. He partido de que la demanda está siempre presente en las relaciones humanas. En otras palabras, todo contacto puede convertirse en un conflicto generador, pero éste, me queda claro, puede estar al servicio del proyecto civilizatorio y la dominación del otro, o a partir del diálogo en horizontalidad de condiciones se puede llegar a la autonomía de la propia mirada. ${ }^{2}$ Más aún, el conflicto generador es condición inevitable para crear el lazo de reciprocidad necesaria para alcanzar la horizontalidad en la investigación.

2 Véase la "autonomía de la propia mirada", más adelante en este libro (p. 40). 


\section{Igualdad discursiva}

Dado que el conflicto generador no tiene que ver con formas armónicas de incorporar la voz de los otros sin comprometer los principios hegemónicos de la investigación, construir conocimiento mutuo tiene que ver con establecer condiciones de equidad que tracen un camino hacia la autonomía de las miradas propias.

La igualdad es una ficción utilizada por el discurso del Estado donde los sujetos son animados a alcanzarla a partir de supuestas oportunidades, dejando de lado el verdadero ejercicio de la política. En México, los grandes programas asistenciales llevan nombres como Oportunidades o Progresa, que dejan ver su intención clientelar dirigida al supuesto desarrollo individual. Se espera que el sujeto, en el mejor de los casos, con capacitación instrumental para el trabajo moderno compita por el ascenso social. Sin embargo, esta estrategia lejos de apoyar la igualdad, se establece para que todos y uno por uno sean absorbidos por el régimen económico, y que la diversidad se esfume en el mercado. Un ejemplo del uso de los recursos de los programas asistenciales dirigidos a los indígenas es el gasto de los apoyos en productos suntuarios de mala calidad que los vendedores ambulantes, conocedores de cómo se activa el programa, ofrecen el mismo día que las beneficiarias cobran su beca mensual.

El debate público, la participación política de la diversidad y las voces múltiples con respecto a los asuntos públicos pasan a segundo término frente a la "oportunidad" de volverse igual en el consumo. No cabe duda de la importancia de alcanzar el bienestar de toda la sociedad, pero también hace falta resaltar "que la interacción entre derecho social e instituciones de bienestar o asistencia configuran categorías sociales, recortan a la sociedad y zonifican lo social. En esta medida cada espacio social se convierte en un referente para la identidad y la acción de segmentos sociales específicos" (Barba 2007, 32).

Hay otro sentido de la igualdad que tiene que ver con lo político como espacio donde dos procesos distintos se conjugan: el de la "policía" o las políticas públicas, y el de los procesos de emancipación (Rançière 
1998). Por un lado, las políticas públicas nombran y así etiquetan a los sujetos y los clasifican en la escala social. Estos nombres se construyen junto con valores y lugares sociales. Nombrar para someter al otro es una práctica remota. Véase por ejemplo la expresión del Inca Garcilaso de la Vega, quien en 1609 ya denunciaba la imposición de nombres.

Garcilaso, a diferencia de Guaman Poma, no puso explícitamente en cuestión los crímenes, ni el vasallaje, ni el derecho territorial, ni la esclavitud, lo que sin duda tampoco hubiera podido hacer bajo el reino de la Inquisición. Más bien elude el tratamiento directo de estos problemas. Y los replantea de nuevo, e indirectamente, por medio de la crítica de su modelo hermenéutico o más bien antihermenéutico, o sea de la imposición de nombre (Subirats 1994, 220).

De esta manera vemos cómo los españoles al nombrar a los incas desde su lugar conquistador, corrompieron su significado y sumaron el plano conceptual a la violencia de la conquista. De acuerdo con Rançière (1998, s/p):

Lo político es el encuentro de dos procesos heterogéneos. El primero es el del gobierno. Éste consiste en organizar la reunión y el consentimiento de los hombres en comunidad y reposa sobre la distribución jerárquica de las posiciones y las funciones. Daré a este proceso el nombre de policía. El segundo proceso es el de la igualdad. Éste consiste en el juego de las prácticas guiadas por la presuposición de la igualdad de cualquiera con cualquiera y por el cuidado de verificarla. El nombre más adecuado para designar esta interacción es el de emancipación. ${ }^{3}$

Frente a estos "nombres correctos" que se imponen y someten, en un proceso emancipatorio donde la igualdad es central se generan los "nombres propios". La policía impone y etiqueta con los nombres co-

3 Una versión traducida por Carissa Sims y Daniel Duque se puede encontrar en: http://www.catedras.fsoc.uba.ar/heler/poliyidenranciere.htm 
rrectos, y, por otro lado, la igualdad discursiva asentará los "nombres incorrectos" que son los propios y son los que guían la autonomía.

Ahora bien, esa igualdad, según Rançière, sólo puede ser individual porque las políticas públicas (o policía) no generan igualdad, son los sujetos los que se emancipan, se nombran y practican su propio nombre. No hay proceso emancipador que no toque el poder de donde emanan los nombramientos correctos. En una canción, Manu Chao resalta: "Me dicen el clandestino/Por no llevar papel", refiriéndose al nombre "correcto" impuesto a tantos migrantes en el mundo. Por otro lado, Gilberto, trabajador maya en Los Ángeles, Estados Unidos, señala: "soy ilegalizado", haciendo evidente que el nombre "correcto" lo definen otros, pero no es propio de su condición. Ser "ilegalizado" lleva en el nombre la denuncia de una realidad impuesta.

De esta manera, aplicado a la PHC, toca revertir el sistema policía del investigador, que reproduce la jerarquía y no escucha ni rescata lo que sí saben todos los demás. La tarea de establecer la igualdad está en las manos del investigador que pretende producir nuevo conocimiento con sus pares investigadores.

El mito académico de la investigación divide las inteligencias en dos: el investigado que sabe responder y el investigador que sabe razonar (es decir, sabe métodos de la CCC). El investigador no horizontal enseña a los investigados sus métodos y sus técnicas (la entrevista, la encuesta, la observación, el análisis de textos, etc.), y de paso a reconocer su superioridad. La PHC parte de lo que saben todos y de sus propios métodos. De esta manera los investigadores se nombran "investigadores pares", concepto que implica que la PHC se realiza a partir de otros nombres, esta vez incorrectos que promueven la igualdad discursiva.

Muchos investigadores tienen buena voluntad y buenas intenciones, buscan educar, apoyar en programas de salud, etc., pero con sus métodos sólo nombran correctamente al otro. El riesgo de nombrar a los investigados como ignorantes es que ellos mismos lleguen a suscribir y aceptar la exclusión de sus conocimientos. 


\section{Silencio de saberes}

Toda comunicación intercultural en el espacio médico es revestida por el ejercicio de poder que tiene el médico sobre cualquier mujer embarazada, indígena o no. La práctica médico-institucional se caracteriza por ser paternalista, asimétrica, jerárquica y autoritaria. El hecho de ignorar la terminología médica establece una condición desigual entre los interlocutores, lo que dificulta el establecimiento de una comunicación eficiente y horizontal que dista de ser verdaderamente intercultural. [...] Se da por sentado que la comunicación intercultural en salud exige de los interlocutores la escucha mutua. Sin embargo, el ritmo está marcado por las relaciones de poder y la institución hospitalaria. Es sustancial comprender el tiempo y espacio de la estructura y funcionamiento del hospital público, que es al mismo tiempo hospital-escuela, porque ninguna comunicación se da en el vacío y sí es producto de condiciones estructurales y culturales. Así alguien interroga (no dialoga), palpa y cede la voz por breves instantes sólo para resolver exclusivamente dudas médicas. Mientras que la indígena embarazada habla sobre sí y permite sin objetar, ser observada y auscultada una y otra vez por un séquito de médicos en formación (residentes e internos) que acompañan al adscrito. La invisibilidad de la embarazada y su familia durante el encuentro comunicativo intercultural está profundamente relacionada con la imposición de la superioridad de unos sobre otros, las distintas clasificaciones sociales organizadas a partir de las diferencias culturales entre grupos sociales explican y justifican la relación asimétrica, jerárquica y autoritaria.

Por otro lado, es imposible no comunicarse. Los silencios, el intercambio de miradas, la distribución y el uso del espacio físico constituyen diálogos no verbales que junto al discurso verbal relatan y reproducen fragmentos de la vida cotidiana, los cuales marcan el inicio y fin de pequeños fragmentos escenificados y actuados por los interlocutores que son parte del orden social.

[...]

Unos y otros se esfuerzan por comunicarse, dialogar, imponer, convencer o negociar durante la comunicación intercultural en sa- 
lud materna. Con el afán de comprenderse, recurren a fragmentos del discurso ajeno que ambos creen conocer. El médico preguntará a la indígena si habla español, se pondrá "a su nivel” usando términos simples, elevará el tono de voz y hablará pausadamente para ser entendido. Si la indígena es bilingüe también conversará en español, en caso contrario será acompañada por algún familiar que le traduzca. La interculturalidad no es ajena a ellos. Desde temprana edad reconocen la utilidad de aprender y comunicarse en castellano, han asimilado fragmentos de la medicina científica debido al contacto cercano que han tenido con ella dándole un nuevo sentido. No ocurre igual con el médico. El no indígena convive en espacios públicos con el indígena con tolerancia y respeto, pero sin que eso signifique un trato cercano ni el establecimiento de relaciones equitativas que quedan intactas por relaciones estructurales de poder. El médico siempre está en ventaja porque la asimetría con la que se relaciona con sus pacientes impide la comunicación intercultural, él es quien maneja la información, la voz autorizada que no valida la experiencia de la embarazada ni los saberes y prácticas indígenas.

Saber qué sucede en los encuentros comunicativos interculturales ayuda a que el encuentro no sea un desencuentro, sino la posibilidad de conocer quién es cada quien frente al otro, para juntos construir nuevos caminos de convivencia y entendimiento en torno a una más cercana interculturalidad en salud materna (Pulido 2017).

Joseph Jacotot, considerado por Rançière (2004) el gran maestro de la emancipación intelectual, elige enseñar una sola cosa -la igualdad- y relacionar todo lo demás a este principio: "Todos los hombres tienen la misma inteligencia”. En la investigación, al rechazar los saberes que todos tienen, se confirma la división entre los que saben y los que no saben. La diferencia entre un investigador par y un investigado es la discrepancia entre responder ante los problemas sociales como investigador o responder como investigado. Cuando la relación se da entre pares, se dialoga entre investigadores, a diferencia de la respuesta del investigado a la pregunta que le cuestiona y parece que examina. El investigador 
par aporta originalidad y el examinado sólo repite lo que corresponde a su nombre correcto. Pasar de objeto de conocimiento a investigador par es reconocernos en la investigación no como objetos pensados por modelos clasificadores, sino como sujetos que piensan.

El riesgo de considerar superior el saber propio es que se desoye lo que saben los demás. La investigación será productora de nuevo conocimiento cuando se haya superado la sociedad de los que saben y los que no saben. Mientras la investigación social ofrezca poco conocimiento nuevo, no podremos explicar los problemas sociales en toda su complejidad y menos encontraremos formas de afrontarlos.

Ahora bien, estos espacios de igualdad no están allí para rescatarlos, si se buscan, no se encuentran. Por ello es más común hacer investigación sobre la base de la desigualdad que se halla por todos lados. Si se plantea como objetivo alcanzar la igualdad a partir de condiciones no igualitarias, se aplaza el resultado al infinito. La igualdad necesaria para el diálogo es responsabilidad del investigador académico, es él quien debe instaurarla. La igualdad discursiva como la entiendo no es un término abstracto sino político y se tiene que ejercer por voluntad. Soy yo como investigadora quien establece un orden de igualdad discursiva para producir un diálogo horizontal. Que quede claro que la igualdad nunca viene después, debe ser punto de partida y debe definírsele antes de empezar a producir conocimiento horizontal.

\section{Autonomía de la propia mirada}

En la investigación social, ¿quién nombra a los participantes del proceso? ¿Cuál es la participación del otro en la construcción de su propio nombre? La PHC argumenta que para conocer como desea ser conocido el otro, no es problema de "haber estado allí" el tiempo suficiente para observar a "su" comunidad, como debaten muchos estudios antropológicos, ni de ser muy claro con las preguntas como se proponen las encuestas de opinión, menos de haber logrado la objetividad anhelada. Durante mucho tiempo se pensó que si se borraban las marcas de la implicación personal, se producía una investigación científica y un 
conocimiento objetivo del otro. Pero esta postura no toma en cuenta que de esta manera el proceso de investigación termina por nombrar al investigado desde el lugar del investigador y sus marcos de interpretación, construyéndolo sin considerar su propia mirada y por lo tanto produciendo conocimiento incompleto.

La autonomía como la entendemos no es una esencia que se debe rescatar, sino que se define por los lenguajes y los contextos. La autonomía que se busca desde la PHC se construye en el intercambio intersubjetivo, donde se aspira a que cada uno exprese su voz de acuerdo con los propios lenguajes y los contextos, con el objeto de que en comunicación se exploren nuevas formas de conocimiento. Con "autonomía de la propia mirada" me refiero a la facultad de expresar el propio nombre desde lugares y formas diversas.

En su sentido más amplio, autonomía es la capacidad "de autodeterminación sin coacción ni violencia ajenas” (Villoro 1993, 137). Nombrarse como se desea, se refiere a la creación de un discurso que otorgue una identidad propia frente a la etiqueta dominante impuesta históricamente. Alejandro Grimson $(2011,15)$ en su libro sobre las identidades reconoce la autonomía cuando los sujetos toman en sus propias manos las decisiones de quiénes son. La disyuntiva no es qué tan puras son sus culturas o cuánto se han apropiado de las demás para pertenecer al Estado nacional o a la modernidad globalizada, o en nuestro caso a la investigación social. La autonomía de la propia mirada implica aquí que todos tienen la facultad de tomar esa decisión.

La autonomía de la propia mirada tiene que ver con el hecho dialógico que se produce entre los dos o más investigadores en horizontalidad, donde el oyente y el hablante toman turnos y traducen lo propio y lo ajeno para construir conocimiento propio y sobre el otro. De esta manera, la autonomía de las miradas lleva a la autonomía de las voces y a la autonomía de la escritura en la PHC. En este sentido, nadie entra a la investigación con una autonomía anterior, esencial, originaria, sino que cada uno se reconoce por la mirada que el otro, en una situación horizontal, le devuelve. Así, uno frente al otro se dicen quiénes son a diferencia del "yo digo quién eres tú" del investigador que no es hori- 
zontal. Nadie es autónomo antes de la experiencia frente a otro, por ello es necesaria la experiencia de la horizontalidad, donde cada uno de los investigadores en el encuentro construye y ejerce su autonomía.

Concebida de esta manera la autonomía se vuelve una poderosa manera de acceder a la igualdad discursiva. Una igualdad que más allá del buen entendimiento de los participantes, es donde la autonomía de las miradas significa aceptar en el otro lo que no entendemos, lo que es suyo y no coincide con lo nuestro. Pero al aceptar su autonomía la tratamos como la nuestra, y la concesión debe ser mutua.

El método para alcanzar la autonomía de la propia mirada durante la PHC pertenece por completo al sujeto, tiene que ver con su propio método de conocer. No hay un método para enseñar autonomía al otro, pues dejaría de nombrarse a sí mismo recurriendo a un nombre impuesto. Rançière señala que el método emancipatorio es anunciar que todos pueden conocer lo que puede un ser humano, en otras palabras, instaurar la igualdad discursiva. No es solo el método lo que somete al ser humano, es el procedimiento mismo de la investigación desigual que no cree en los múltiples conocimientos sociales o, si los reconoce, los desacredita y domina.

Ahora bien, la autonomía se construye frente a la mirada que el otro devuelve. Lo que se opone a la autonomía no es la aceptación y apropiación del concepto ajeno, sino es la sumisión a un discurso extraño que nombra y jerarquiza. En algunos casos la apropiación de ideas ajenas puede favorecer la autonomía, por ejemplo el caso de los movimientos sociales que se nombran a partir de ideas provenientes de centros dominantes. Nombrarse como se desea, a partir de conceptos reconocibles por el otro dominante, puede llegar a afirmar su autonomía.

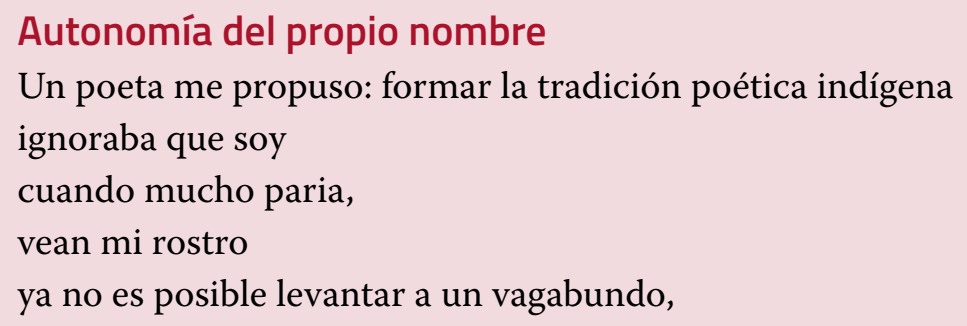


luego me dijo: ¡arriba la etnopoética!

Me enteré que era etnohistoriador, me dio gusto

me hablaba en etno: música, danza, ambulante, etno, etno, puro.

Ay, etnoamigo

y conversamos en etnoindio,

otro poeta nos corrigió y nos dijo que éramos etnoindígenas

se dio cuenta que hablábamos un lenguaje indigenioso

más bien indiof ílico, le dije.

Le pregunté: ¿escribimos para seguir comiendo la etnotorta?

No supo qué contestarme, pero la rueda gira y también el

aguardiente,

déjenme decirles que ahora es mi mejor amigo

(Tatyisavi 2014).

La igualdad discursiva emancipa y autoriza la autonomía porque pone al descubierto a investigadores que ignoran las respuestas a un problema, pero a la vez traducen diversos conocimientos, se entienden y buscan las palabras y las ideas que generan un tercer texto. A nuestro parecer, no es cuestión de perder el tiempo en buscar una verdad oculta del mundo social, en nuestra investigación "no se trata del irrisorio poder de levantar el velo de las cosas, sino de la potencia de traducción que confronta a un orador con otro" (Rançière 2007, 87); es decir, la fuerza de la traducción de la que habla el autor implica que no hay un nivel del conocimiento que se subordina a otro, sino que es gracias al encuentro de sujetos que se traducen mutuamente, que resulta la autonomía de los que pueden construir nuevo conocimiento.

El objetivo del investigador horizontal es plantear sus propios intereses frente a otro considerado su investigador par, para así asegurar el éxito de la PHC. Ambos investigadores buscan la autonomía de sus voces en diálogo con el otro. Para Villoro $(1993,137)$, el encuentro de las autonomías debe poder: 
1) Fijar sus metas, elegir sus valores prioritarios, establecer preferencias y determinarse por ellas. 2) Ejercer control sobre los medios a su alcance para cumplir esas metas. 3) Establecer los criterios para la justificación de sus creencias y atenerse, en el proceso, a las razones de que esa comunidad dispone. 4) Seleccionar y aprovechar los medios de expresión que juzgue más adecuados.

No sólo hablamos de los derechos a utilizar cada quien sus conocimientos y fijar sus metas, además de definir los procedimientos para cumplirlos y generar nuevo conocimiento, sino que la autonomía de la propia mirada implica que lo es frente a otra, y que en diálogo se encuentran las respuestas a las preguntas que atañen a todos. La PHC persigue un doble objetivo: el conocimiento que responda a los problemas sociales y el desarrollo de la relación autónoma entre las personas.

\section{Nombrar la responsabilidad}

Estamos lejos del tiempo en que se ignoraba la responsabilidad ética del investigador. En la actualidad cuida sus relaciones con sus "anfitriones" en el campo y prefiere ser cordial y hasta afectuoso con sus comunidades. Entonces, ¿la PHC se explica por una postura ética frente a la investigación, más que por un método distinto de investigación? La PHC a la que nos referimos conlleva desde luego una reflexión ética: el tema de la reciprocidad como fundamento de la construcción de conocimiento con el otro, la expresión clara de las intenciones investigativas, la apertura al diálogo y a la negociación de objetivos, y la centralidad de la escucha proponen una tarea que marca por principio la relación con el otro, que se convierte en esta investigación en un igual discursivo. Nuestro propósito es encontrar nuevos conceptos que nombren la realidad social de maneras diversas. No nos proponemos cumplir con una ética individual para el trabajo de campo con los mismos conceptos de siempre, ya que consideramos que el respeto al otro exige un comportamiento que asegure la igualdad del encuentro discursivo y por lo tanto también 
la búsqueda conjunta sobre la ética en el proceso de investigación, una ética que sea válida para el espacio compartido, que sea política.

Así, la reflexividad como método que orienta el comportamiento ético del investigador individual, en el sentido que Bourdieu $(2013,528)$ recomienda: "percibir y controlar sobre la marcha, en la realización misma de la entrevista, los efectos de la estructura social en la que ésta se efectúa", no nos parece suficiente para contrarrestar el sueño positivista que bien señala el autor más adelante y que "enmascara, en efecto, el hecho de que la diferencia no es entre la ciencia que efectúa una construcción y la que no lo hace, sino entre la que lo hace sin saberlo y la que, sabiéndolo, se esfuerza por conocer y dominar lo más completamente posible sus actos, inevitables, de construcción y los efectos que, de manera igualmente inevitable, éstos producen" (Ibid.). Nuestra postura coincide con la crítica a los métodos positivistas, pero no con el método reflexivo de superarlo. Pues ¿cómo conocer los propios actos si sólo tenemos un lenguaje, una voz que nos ha enseñado a ser investigadores, a respetar la jerarquía del conocimiento que surge de la academia, a mirar al otro como objeto de investigación? El ejercicio de introspección se lleva a cabo con el lenguaje y es ingenuo esperar encontrar y reconocer en nuestro actuar, algo misterioso para lo que no tenemos palabras para nombrar. Sucede lo mismo con la pretendida "doble reflexividad". La propuesta es desplazarse de la subjetividad que "piensa y luego existe", a la intersubjetividad donde los investigadores pares son la fuente de la autoridad.

Cuando nos retiramos del planteamiento abstracto de la autoreflexividad, no hay otra manera de tomar distancia o hacer análisis crítico de nuestra mirada sobre el otro que contrastando nuestro saber con otros léxicos y otras formas de pensar. Nuestra propuesta frente a la reflexividad es instaurar una forma discursiva horizontal, donde el otro se exprese como desea, aporte con su conocimiento y además ponga límites -con su lenguaje- a nuestro propio discurso incompleto. De la misma manera, nosotros devolvemos al suyo nuestra mirada, y juntos en diálogo fecundo construimos nuevo conocimiento en un contexto horizontal. 


\section{Reciprocidad}

El tema de la reciprocidad amerita una desviación temática en este lugar porque es una de las conductas que más confusión causa en el trabajo investigativo. Reciprocidad se acerca a conceptos como solidaridad, ayuda y compasión. Cuando se investiga con otros, muchas veces se pone en juego no sólo la diferencia entre los llamados investigados y los investigadores, sino la desigualdad social entre ambos. Cuando se realiza el trabajo con comunidades marginadas, con bajos ingresos y que disponen de servicios mínimos educativos, de salud, seguridad, etc., este hecho puede provocar compasión y el deseo de convertirse en voluntario para resolver sus problemas. La buena intención del voluntario que desea ayudar a la comunidad que encuentra en grandes apuros, inmersa en la desigualdad y la injusticia, es muy loable y en algunos casos las acciones del voluntariado resuelven lo que las instancias formalmente responsables no habían logrado. Sin embargo, debe reconocerse que también causa problemas que se yuxtaponen y éstos deben evitarse. Primeramente, construir una relación desequilibrada entre voluntario-receptor donde el segundo no tiene nada que devolver sólo provoca más sometimiento y desigualdad. Por otro lado, el cansancio que Sennett llama la "fatiga de la compasión", es decir, cuando el voluntario termina por retirarse de la investigación y de esta manera se aleja también de la ayuda recíproca que podría construirse en horizontalidad.

Este tipo de asistencia social, si no se tiene clara, puede evidenciarse en la investigación, donde el asistido se convierte en un sujeto dependiente, sin lugar ni reconocimiento de su autonomía, ni concesión a sus propias formas de encarar los problemas sociales. Sennett retoma la frase "la compasión que hiere" para resaltar la jerarquía que se construye en las relaciones desiguales y el poder autoritario que posee el regalo. La ayuda entregada sin contraprestación "puede herir el respeto por sí misma de la persona que lo recibe, pues la 'caridad hiere', como dice la antropóloga Mary Douglas, deja una carga pesada de gratitud en el receptor, quien puede tener nada que devolver, salvo la sumisión" (Sennett 2003, 155).

La reciprocidad en la PHC contempla el valor social de la investigación en otros términos. Los límites y la claridad de las fronteras de la in- 
vestigación horizontal ayudan a construir espacios de igualdad donde el reconocimiento mutuo de la diferencia fortalezca el respeto por el otro, por uno mismo y por la autonomía de las miradas del mundo. La investigación, como otros trabajos, puede perdurar mucho tiempo cuando la reciprocidad es entendida en términos equitativos y se encuentra conocimiento de ambos lados.

\section{Hospitalidad}

Entre el 7 y el 10 de junio de 2011 se llevó a cabo allí, en San Cristóbal, el encuentro de la International Association for Intercultural Studies, ese año bajo la convocatoria: "Nosotros y los otros en la comunicación intercultural: retos y posibilidades de un espacio común", en las instalaciones de la Universidad Intercultural de Chiapas.

[...]

El espacio y la convocatoria, sin embargo, fueron peculiares. Llegar al auditorio creado ex profeso para el encuentro, posicionó a todos los foráneos en la necesidad de significar un paisaje: con el telón de fondo de la selva lacandona, una carpa se erigía cobijando a ponentes, conferencistas, oyentes. Cuando hablamos de paisaje, como sabemos, no estamos aludiendo a una configuración objetiva del espacio: el paisaje presupone una mirada, un código. En esa codificación, el sujeto que mira es también sujeto mirado. La pregunta es: en Chiapas, en junio de 2011, ¿quién-es eran/éramos nosotros y quién-es los otros? ¿De qué manera íbamos a trabajar con esas categorías en un encuentro destinado a la Comunicación Intercultural en perspectiva transnacional? Hago estas preguntas porque uno de los elementos que posicionó a un nosotros (académicos, investigadores, etc.) frente al dilema fue justamente el descentramiento del paisaje. Entiéndase bien, no por la posición natural de un terreno, sino porque nuestra mirada aparentemente experta se vio reubicada: en Chiapas, en junio pasado, hablar de nosotros y los otros no tenía el sentido académico clásico de fijar una diferencia y diseccionarla o estudiarla, sino de fundar lo que me gustaría llamar una epistemología de la hospitalidad. Me da la impresión de que pocos de nosotros estábamos armados para afrontar una 
experiencia de ese tipo, y que los organizadores del encuentro fueron nuestros formadores en ese punto.

De ellos aprendimos que la horizontalidad en la investigación social es posible en un momento discursivo fundado en la hospitalidad. Ese momento en el que se reconoce la diferencia, la asimetría; en el que se asume la distancia entre un investigador que enseña y aprende en las comunidades indígenas tzeltales, aquel que enseña en el Distrito Federal mexicano y aquel que escribe sobre tecnología global en China. En cualquiera de estos casos, en el encuentro de Chiapas había una decisión tomada: la que supone (como Bajtín ya pregonaba) que sólo desde la diferencia es posible el diálogo y que en definitiva, se dialoga para transformar-se -y no para mimetizarse-. El recibimiento que nos dio la Universidad Intercultural de Chiapas no podría haber sido más congruente con una política del conocimiento situado: dispuso ante nosotros esa marca del paisaje políticamente significado (la selva lacandona), para proponernos una hospitalidad sin garantías. A diferencia de otros formatos de congreso-seminario-simposio, nada se nos pidió a cambio. Excepto una actitud: la escucha. Se nos propuso comprender [...] (Rufer 2012c).

Como ejemplo inspirador están las formas indígenas de trabajo recíproco como el tequio o la minga. La investigadora Yvonne Riaño ha designado con el nombre de minga el trabajo metodológico que realiza y que se desprende de la práctica quechua de la minga en los países andinos. Su propósito es alcanzar relaciones más igualitarias entre los investigadores e investigados, socios de la investigación: "Esta es una forma de trabajo colectivo en el que no existe un intercambio económico sino el mutuo beneficio de toda/os los miembros de la comunidad" (Riaño 2012, 137). Lo que al investigador de las CCC puede extrañarle es que en la PHC no hay perdedores, un investigador permanece ligado a otro por la asistencia mutua y el vínculo está pactado por el dar, recibir, asistir y devolver (Giebeler y Meneses 2012).

Claro está que la reciprocidad se complejiza al no llevarse a cabo a partir de los mismos puntos de partida de todos los participantes en el momento de los acuerdos que implica la investigación horizontal. El 
dinero, el pago de servicios, la compra de algo a la que no todos pueden acceder, los intereses propios, son temas en sí que atraviesa el proceso. El conflicto generador pasa por establecer la reciprocidad y sus términos, y puede ser también el primer ingreso al conocimiento mutuo.

La reciprocidad también debe ser pensada más allá del trabajo de campo, es tarea del investigador horizontal imaginar los intercambios recíprocos ampliados e inagotables: en la docencia en el aula, en la escritura en otras lenguas, en la incorporación cotidiana de conocimiento aprendido en otros lugares. En palabras de Gustavo Blázquez, se trata de "retribuir en otras direcciones; dar a los que no me dieron". De otra forma, esto es ser "tocado" por el discurso del otro, transformado (Martín y Corona 2017).

Ahora bien, una pregunta difícil de responder: ¿cómo aplicar la horizontalidad en situaciones de claro conflicto ético, por ejemplo con caciques, políticos corruptos o perpetradores, o bien, cuando la aproximación es con las víctimas? Primero se exige una reflexión en torno al motivo de la investigación y a los objetivos del investigador que desea conocer: ¿le interesa producir una investigación que va más lejos de lo establecido por el sentido común y las versiones oficiales? ¿Para qué? ¿Cuál es el objetivo del investigador par y qué desea producir en horizontalidad?

Para Alejandro Castillejo $(2016,133)$, investigar en estas condiciones conlleva una carga ética en el sentido profundo, más allá del sentido contractual del proceso investigativo entre investigador e investigado:

¿Cómo hacemos para que la investigación sea con otros seres humanos y no sobre otros seres humanos? [...] Cuando uno ha construido relaciones de intimidad con otras personas -a raíz de su sufrimiento-. Se gesta un universo moral particular donde la pregunta por la verdad del dolor del otro no es sólo una pregunta pragmática sino una pregunta filosófica y moral y, por supuesto, política.

Comunicar los resultados que se construyen en diálogo con personas que han hecho daño y dolor extremo, comporta riesgos; hacer conocer a las víctimas los hechos de sus perpetradores desde su propia voz, puede considerarse como una intrusión, una falta de respeto, una 
mentira que no se acepta, una impertinente reapertura de heridas, o simplemente se rechaza.

Con relación a Sendero Luminoso, se ha constatado que muchas víctimas de la violencia senderista se convirtieron en perpetradores y el ajuste de cuentas hasta la fecha se hace muy problemático. ¿Hay horizontalidad posible cuando están en juego las posturas éticas personales del investigador? Como hijo de senderistas, José Carlos Agüero se ha dedicado a tratar de entender las dimensiones del arrepentimiento y el perdón, y ha encontrado lo difícil de la tarea. Como dice él mismo, entender "el modo en el que compartimos (perpetradores y víctimas) dilemas sociales éticos en un presente nacido de tanta violencia”. El siguiente es un fragmento de su libro Los Rendidos. Sobre el don de perdonar en su encuentro con un antiguo senderista:

Quizás porque éramos más o menos contemporáneos, quizás porque le conté algunas cosas en privado, porque le regalé un libro. No sé. Juan me enseñó las tumbas donde habían enterrado a los senderistas y a sus propios vecinos que habían sido de Sendero en la zona. Era el secreto de la comunidad [...].

Juan me dice que no les importa tanto las reparaciones, que están bien, pero que sobre todo quieren una cosa. Me dice que le pida a la Comisión de la Verdad que les ayude a reconciliarse con sus hermanos de la comunidad de Ichu. Que los perdonen [...]. Que la Comisión le ayude para que los perdonen los de la comunidad vecina. Que entiendan que muchos fuimos obligados, o que lo hicimos sin saber mucho, yo mismo fui, niño era, a esa batalla, cuando los matamos dirigidos por Sendero. Desde allí nos odian. Y estamos arrepentidos (Agüero 2015, 47-48).

El autor tiene una postura complicada, reconoce los crímenes de Sendero pero busca el perdón de las víctimas porque considera que el sufrimiento no es de un solo lado. Su investigación, ¿de qué lado puede estar? ¿Puede ser horizontal con unos y con otros? No hay una sola respuesta ni un solo camino, son necesarios nuevos lenguajes, otras palabras para la reconciliación: "Entiendo que [Juan] necesita paz, que su 
conciencia necesita ser calmada, que saber que otros lo odian con razón no le impide vivir, pero lo marca. Algo le digo, alguna fórmula desde el idioma de los derechos humanos. Pero sé que solo son palabras inútiles" (Ibid., 48).

¿Cómo construir un tercer texto con todos los involucrados en el problema y por lo tanto también de la solución? ¿Cómo ser horizontal con víctimas y perpetradores que en diferentes momentos tomaron ambos lugares? ¿Insistir en elaborar una memoria con igualdad discursiva o dejar que el olvido se imponga? ¿Rescatar la memoria de las víctimas y los perpetradores, pero respetando el dolor de la gente, apostando a que quizás a la larga sea la más provechosa?

La investigación debe responder a los mandatos de la PHC, es decir, que sea entre pares investigadores, que se respete la reciprocidad y tenga algún provecho significativo para todos. Pero a la vez los investigadores no pueden olvidar que tienen también su propia voz y la responsabilidad moral y política de condenar las acciones que llevan a la violencia, a la dominación y al sufrimiento. Construir conocimiento con el investigador par no tiene que ver con lo que se conoce como el consentimiento informado de los entrevistados, menos con la objetividad del entrevistador o con su compasión. Las respuestas no son fáciles y tampoco pueden ser generalizables a todos los casos. Sin embargo, en la PHC el resultado de la investigación no puede ser la simple reproducción estéril del discurso hegemónico y tampoco su descripción y transgresión sin sentido. Por ahora, los problemas quedan aquí planteados en busca de nuevos lenguajes. 


\section{Ordenar}

Para Foucault, el orden aparece como un fundamento histórico, donde las instrucciones se nos dan como evidentes, porque en la organización misma operan las restricciones que hacen posible que se reconozca como el orden natural de las cosas. La dinámica del conocimiento depende en gran medida del "respeto" al orden que formulan los conceptos, las teorías, los modelos y las reglas para la experiencia empírica. De esta manera, lo que vemos y definimos como valioso en la investigación está definido por una construcción categorial ordenadora. No es de extrañar entonces que, a falta de otros ordenamientos, el mismo sea utilizado muchas veces como explicativo de los problemas con los que se enfrentan las ciencias sociales. Raymundo Mier $(2010,258)$ señala que:

por más asombroso, por más prometedor, por más singular, por más iluminador que aparezca un hecho ante la percepción, si no encuentra las condiciones de construcción potencial de esa inteligibilidad en el orden de las categorías, permanece en la oscuridad, perdida en el mismo instante toda posibilidad de engendrar significación, de consolidar la sorpresa en experiencia; habrá de permanecer en silencio, confinada al olvido, en la oscuridad. Se requiere por lo tanto no la existencia de categorías, sino la existencia de esferas de categorías en estructuras consistentes, cuando menos en estructuras abiertas capaces de alentar y articular la comprensión.

A continuación exploramos el contenido del orden que se reproduce en las instituciones que hacen investigación social, y al comparar con la PHC esperamos desmontar uno por uno sus criterios formales para llegar 
a una propuesta abierta y flexible. Queda claro que más que un nuevo recetario a seguir, las próximas páginas son sugerencias que al comportar otro contenido guían un orden diferente y una manera distinta de hacer ciencia social. Ubicar mi propia investigación desde los métodos horizontales (Corona y Kaltmeier 2012), me ha llevado a entender otros conceptos, teorías y métodos, los cuales ordenan en forma diferente lo que pensamos sobre los problemas que pertenecen no sólo a la academia.

En el siguiente cuadro comparativo se distinguen las categorías consideradas científicas en las principales perspectivas de las ciencias sociales. Esta síntesis corresponde a las categorías elaboradas por el Consejo Nacional de Investigación (NRC por sus siglas en inglés) de Estados Unidos, donde se catalogan las diferencias entre la perspectiva de la CCC y la investigación-acción en práctica en Estados Unidos y Alemania. En la cuarta columna agrego una descripción sintética de la investigación horizontal, que se explicará a continuación con mayor detalle. Con base en estos criterios se comparan las tres formas metodológicas de aproximación a los fenómenos sociales (véase tabla 1).

\begin{tabular}{|l|l|l|l|}
\hline \multicolumn{4}{|c|}{$\begin{array}{l}\text { Tabla 1. Categorías para la investigación } \\
\text { en tres perspectivas cientificas }\end{array}$} \\
\hline \multicolumn{1}{|c|}{$\begin{array}{l}\text { Descripción } \\
\text { general }\end{array}$} & \multicolumn{1}{|c|}{ Principios ccc } & \multicolumn{1}{|c|}{$\begin{array}{c}\text { Investigación- } \\
\text { acción }\end{array}$} & \multicolumn{1}{c|}{$\begin{array}{c}\text { Métodos } \\
\text { horizontales }\end{array}$} \\
\hline $\begin{array}{l}1 . \\
\text { Preguntas }\end{array}$ & $\begin{array}{l}\text { Plantear } \\
\text { preguntas } \\
\text { significativas } \\
\text { que se puedan } \\
\text { investigar } \\
\text { empíricamente. }\end{array}$ & $\begin{array}{l}\text { Identificar } \\
\text { preguntas o } \\
\text { problemas. }\end{array}$ & $\begin{array}{l}\text { Construir el } \\
\text { objeto de estudio } \\
\text { con el par } \\
\text { investigador. }\end{array}$ \\
\hline $\begin{array}{l}\text { Teoría y marco } \\
\text { conceptual }\end{array}$ & $\begin{array}{l}\text { Vincular la } \\
\text { investigación } \\
\text { con la teoría } \\
\text { relevante. }\end{array}$ & $\begin{array}{l}\text { Diseñar y aplicar } \\
\text { intervenciones } \\
\text { basadas en teorías } \\
\text { de la práctica. }\end{array}$ & $\begin{array}{l}\text { Planear la } \\
\text { investigación a } \\
\text { partir de ambos } \\
\text { marcos teórico- } \\
\text { prácticos. }\end{array}$ \\
\hline
\end{tabular}

4. Principios básicos de calidad científica en la investigación elaborada por el NRC de Estados Unidos (Anderson 2015). 


\section{Tabla 1. Categorías para la investigación en tres perspectivas cientificas}

\begin{tabular}{|c|c|c|c|}
\hline $\begin{array}{l}\text { Descripción } \\
\text { general }\end{array}$ & Principios $\operatorname{ccc}^{4}$ & $\begin{array}{c}\text { Investigación- } \\
\text { acción }\end{array}$ & $\begin{array}{c}\text { Métodos } \\
\text { horizontales }\end{array}$ \\
\hline $\begin{array}{l}3 . \\
\text { Métodos y } \\
\text { procedimientos }\end{array}$ & $\begin{array}{l}\text { Métodos que } \\
\text { permitan la } \\
\text { investigación } \\
\text { directa de las } \\
\text { preguntas. }\end{array}$ & $\begin{array}{l}\text { Recolectar datos } \\
\text { sistemáticamente. }\end{array}$ & $\begin{array}{l}\text { Practicar } \\
\text { el diálogo } \\
\text { horizontal: } \\
\text { conflicto } \\
\text { fundador, } \\
\text { igualdad } \\
\text { discursiva y } \\
\text { autonomía de } \\
\text { la propia mirada. }\end{array}$ \\
\hline $\begin{array}{l}4 . \\
\text { Análisis e } \\
\text { interpretación }\end{array}$ & $\begin{array}{l}\text { Proporcionar } \\
\text { una cadena } \\
\text { coherente y } \\
\text { explícita de } \\
\text { razonamiento } \\
\text { para eliminar las } \\
\text { interpretaciones } \\
\text { contrarias. }\end{array}$ & $\begin{array}{l}\text { Analizar datos y } \\
\text { reflexionar sobre su } \\
\text { significado. }\end{array}$ & $\begin{array}{l}\text { Construir } \\
\text { conocimiento } \\
\text { nuevo de forma } \\
\text { dialógica, un } \\
\text { tercer producto. }\end{array}$ \\
\hline $\begin{array}{l}5 . \\
\text { Publicación } \\
\text { y crítica }\end{array}$ & $\begin{array}{l}\text { Divulgar la } \\
\text { investigación } \\
\text { para alentar } \\
\text { el escrutinio } \\
\text { y la crítica } \\
\text { profesionales. }\end{array}$ & $\begin{array}{l}\text { Compartir esfuerzos } \\
\text { individuales con } \\
\text { otros integrantes } \\
\text { de la comunidad } \\
\text { (conferencias, } \\
\text { boletines, revistas } \\
\text { orientadas hacia } \\
\text { los practicantes). }\end{array}$ & $\begin{array}{l}\text { Autoría a } \\
\text { varias voces. }\end{array}$ \\
\hline $\begin{array}{l}6 . \\
\text { Reproducción }\end{array}$ & $\begin{array}{l}\text { Reproducir y } \\
\text { generalizar los } \\
\text { hallazgos. }\end{array}$ & $\begin{array}{l}\text { Participar en la } \\
\text { investigación } \\
\text { colaborativa, repetir } \\
\text { intervenciones } \\
\text { con otras clases de } \\
\text { estudiantes o en } \\
\text { otros entornos. }\end{array}$ & $\begin{array}{l}\text { Productos del } \\
\text { proceso dialógico } \\
\text { en distintos } \\
\text { contextos } \\
\text { para discutir } \\
\text { horizontalmente } \\
\text { en varios campos. }\end{array}$ \\
\hline
\end{tabular}


El campo científico está en permanente debate en torno a si debe haber principios científicos homogéneos que guíen y validen toda investigación que se pretenda científica. Sin entrar en esta discusión, enuncio los conceptos metodológicos que se consideran pueden garantizar la producción de conocimiento desde las CCC. En otras palabras, los métodos de la investigación normalizada van de la mano con los métodos enfocados a validar los reclamos de la producción científica. En EUA el NRC se encarga de articular la investigación con las estructuras consideradas válidas para producir conocimiento. La función verificadora se lleva a cabo a partir de seis principios ordenadores que se describen en la tabla 1. Estos principios reflejan el interés por privilegiar la evidencia empírica, la evaluación de los resultados y la exclusión de la construcción alternativa del conocimiento.

Anderson (2015) concibe cada uno de los criterios considerados por el NRC como principios rectores de calidad científica, y agrega a la discusión una columna dedicada a compararlos con los de la investigación-acción. El autor observa que los seis criterios de la CCC desempeñan también su papel ordenador en la investigación-acción, aunque se refieran a una aplicación diferente.

Nosotros hemos agregado una cuarta columna a la derecha del cuadro por el interés de comparar las anteriores y muy conocidas propuestas con la nuestra. En este resumen, a partir del orden original, podemos observar la forma en que los cómo del hacer científico con métodos horizontales se modifican y distinguen de la CCC y de la investigación-acción. Dedicamos el resto del capítulo a explicar cada criterio a partir de los tres conceptos fundadores que en nuestro caso atraviesan y determinan cada paso del proceso de la PHC.

La horizontalidad que nos guía en la PHC considera los tres presupuestos básicos para construir conocimiento que fueron discutidos en el capítulo anterior: el conflicto generador, la igualdad discursiva y la autonomía de la propia mirada. Estos tres ejes atraviesan las seis categorías de la investigación que es horizontal (véase tabla 2). Las categorías expuestas como pasos metodológicos nos permiten comparar nuestra propia propuesta horizontal con la llamada "ciencia con criterios científicos" (Schavelson, Towne y Fever), críticamente llamada "normal” (Kuhn y Lander) o 
"dogmática" (Epstein). A continuación, cada una de las categorías se describen a partir de los tres conceptos fundadores de la PHC.

\begin{tabular}{|c|c|c|c|}
\hline & $\begin{array}{l}\text { Conflicto } \\
\text { generador }\end{array}$ & $\begin{array}{l}\text { Igualdad } \\
\text { discursiva }\end{array}$ & Autonomía \\
\hline $\begin{array}{l}\text { 1. Preguntas. } \\
\text { Construir } \\
\text { objeto de } \\
\text { estudio } \\
\text { con el par } \\
\text { investigador. }\end{array}$ & $\begin{array}{l}\text { Sustituir } \\
\text { objetividad por } \\
\text { intersubjetividad } \\
\text { en forma de } \\
\text { diálogo libre } \\
\text { entre aquellos que } \\
\text { hacen preguntas } \\
\text { juntos. }\end{array}$ & $\begin{array}{l}\text { Las preguntas } \\
\text { no responden a } \\
\text { las necesidades } \\
\text { previamente } \\
\text { construidas por un } \\
\text { investigador, sino } \\
\text { que se construyen } \\
\text { en conjunto entre } \\
\text { los investigadores } \\
\text { pares. }\end{array}$ & $\begin{array}{l}\text { El investigador } \\
\text { par no sólo } \\
\text { cambia una forma } \\
\text { investigativa, sino } \\
\text { la relación entre } \\
\text { las personas. }\end{array}$ \\
\hline $\begin{array}{l}\text { 2. Teoría } \\
\text { y marco } \\
\text { conceptual. } \\
\text { Planear la } \\
\text { investigación a } \\
\text { partir de ambos } \\
\text { marcos teórico- } \\
\text { prácticos. }\end{array}$ & $\begin{array}{l}\text { La teoría y la } \\
\text { práctica son parte } \\
\text { de un mismo } \\
\text { proceso y no } \\
\text { necesariamente } \\
\text { los conceptos } \\
\text { teóricos anteceden } \\
\text { a la práctica y } \\
\text { determinan su } \\
\text { contenido. }\end{array}$ & $\begin{array}{l}\text { La investigación es } \\
\text { considerada como } \\
\text { expresión de la } \\
\text { vinculación entre } \\
\text { las teorías y las } \\
\text { prácticas de ambos } \\
\text { investigadores } \\
\text { pares. }\end{array}$ & $\begin{array}{l}\text { Construir una } \\
\text { racionalidad } \\
\text { interdiscursiva } \\
\text { entre mundos } \\
\text { culturales } \\
\text { distintos. }\end{array}$ \\
\hline $\begin{array}{l}\text { 3. Métodos y } \\
\text { procedimientos. } \\
\text { Practicar el } \\
\text { diálogo } \\
\text { horizontal. }\end{array}$ & $\begin{array}{l}\text { Frente a la } \\
\text { intervención } \\
\text { como violencia, la } \\
\text { intervención como } \\
\text { conflicto fundador. } \\
\text { A diferencia de la } \\
\text { intervención en } \\
\text { espacios normados } \\
\text { con anticipación, } \\
\text { la intervención } \\
\text { como creadora de } \\
\text { espacios híbridos. }\end{array}$ & $\begin{array}{l}\text { Igualdad que se } \\
\text { tiene que ejercer } \\
\text { por voluntad. } \\
\text { Soy yo como } \\
\text { investigadora } \\
\text { responsable de } \\
\text { instaurar un } \\
\text { orden de igualdad } \\
\text { discursiva } \\
\text { para producir } \\
\text { conocimiento } \\
\text { conjunto. }\end{array}$ & $\begin{array}{l}\text { Tiene que ver con el } \\
\text { hecho dialógico que } \\
\text { se produce entre } \\
\text { los investigadores, } \\
\text { donde el oyente y } \\
\text { el hablante toman } \\
\text { turnos y traducen } \\
\text { lo propio y lo ajeno } \\
\text { para construir } \\
\text { conocimiento } \\
\text { propio y sobre el } \\
\text { otro. }\end{array}$ \\
\hline
\end{tabular}




\begin{tabular}{|c|c|c|c|}
\hline & $\begin{array}{l}\text { Conflicto } \\
\text { generador }\end{array}$ & $\begin{array}{l}\text { Igualdad } \\
\text { discursiva }\end{array}$ & Autonomía \\
\hline $\begin{array}{l}\text { 4. Análisis e } \\
\text { interpretación. } \\
\text { Construir } \\
\text { conocimiento } \\
\text { nuevo de forma } \\
\text { dialógica, un } \\
\text { "tercer texto". }\end{array}$ & $\begin{array}{l}\text { El análisis y la } \\
\text { interpretación } \\
\text { dialógicos no } \\
\text { excluyen las } \\
\text { contradicciones } \\
\text { que se generan a } \\
\text { cada paso, sino } \\
\text { que son insumo } \\
\text { para crear nuevo } \\
\text { conocimiento. }\end{array}$ & $\begin{array}{l}\text { Frente a la } \\
\text { comparación de } \\
\text { perspectivas, su } \\
\text { conexión. }\end{array}$ & $\begin{array}{l}\text { Interpretación y } \\
\text { mutua afectación. }\end{array}$ \\
\hline $\begin{array}{l}\text { 5. Publicación } \\
\text { y crítica. } \\
\text { Autoría a varias } \\
\text { manos. }\end{array}$ & $\begin{array}{l}\text { Exposición } \\
\text { pública, } \\
\text { retroalimentación, } \\
\text { crítica y diálogo. }\end{array}$ & $\begin{array}{l}\text { Igualdad } \\
\text { discursiva en la } \\
\text { presentación del } \\
\text { producto dialógico } \\
\text { o "tercer texto", } \\
\text { escritura "entre } \\
\text { voces". }\end{array}$ & $\begin{array}{l}\text { Autonomía } \\
\text { para expresar } \\
\text { una mirada no } \\
\text { universal, sino de } \\
\text { acuerdo con cada } \\
\text { contexto. }\end{array}$ \\
\hline $\begin{array}{l}6 . \\
\text { Reproducción. } \\
\text { Producir } \\
\text { materiales de } \\
\text { investigación } \\
\text { para discutir en } \\
\text { varios campos: } \\
\text { ni replicabilidad } \\
\text { ni recetas. }\end{array}$ & $\begin{array}{l}\text { Tejido de saberes } \\
\text { y razones, } \\
\text { modificable } \\
\text { contextualmente. } \\
\text { Conocimiento } \\
\text { permanentemente } \\
\text { inacabado. }\end{array}$ & $\begin{array}{l}\text { El producto no } \\
\text { pretende ser } \\
\text { homogéneo, ni } \\
\text { uno solo híbrido, } \\
\text { sino múltiple } \\
\text { e historizado, } \\
\text { donde se observe } \\
\text { que la voz de } \\
\text { uno es siempre } \\
\text { determinada por la } \\
\text { voz del otro. }\end{array}$ & $\begin{array}{l}\text { La investigación } \\
\text { debe considerar } \\
\text { todos los eslabones } \\
\text { posibles para crear } \\
\text { conocimiento } \\
\text { sobre el cómo } \\
\text { vivir mejor en } \\
\text { comunidad, } \\
\text { conectarlos en un } \\
\text { plano horizontal } \\
\text { y aceptar que } \\
\text { es falible y } \\
\text { provisional. }\end{array}$ \\
\hline
\end{tabular}




\section{Preguntas}

¿Cómo empiezo? ¿Selecciono un enfoque conocido o más bien opto por un problema de interés independiente de un enfoque teórico tradicional? Parecería que estos son los dos caminos que la CCC nos ofrece para iniciar una investigación. En PHC empezamos por la construcción conjunta de las preguntas que nos permiten tomar en cuenta los saberes académicos y aquellos que las personas saben, viven y desarrollan en sus vidas diarias. El inicio de la investigación empieza con preguntas que se han relacionado con problemas que desde lugares distintos guían la decisión para investigar. Recurro al ejemplo de la pregunta con la que se inició la reflexión sobre los problemas sociales en un evento zapatista. En diciembre de 2016, el EZLN convocó a 84 científicos occidentales a un evento internacional. El título del evento fue "La culpa es de la flor", donde se invitaba a discutir los fenómenos de nuestro entorno desde todos los ámbitos posibles. En la inauguración, el subcomandante Galeano relató que una joven de la comunidad le había preguntado por qué la flor tenía ese color, ese olor, esa forma, y la misma joven aclaraba que ella sabía que era por la providencia de la madre tierra, pero que ahora buscaba otra respuesta, la que daban otros saberes. La reunión en San Cristóbal de las Casas promovía de esta manera una pregunta epistemológica: ¿cómo explican los otros el mundo? El olor de las flores, pero creemos que también la violencia urbana, la precarización de millones de habitantes, las muertes violentas que nos rodean, la exclusión de los pueblos indígenas y de todos los que son diferentes, son sólo algunos hechos que podemos investigar con otros, en diálogo, construyendo preguntas desde distintas voces para llegar a comprender los problemas que no son explicables desde un solo punto de vista.

Si la propuesta de la PHC es que la capacidad de hacer preguntas no es exclusiva de la academia sino que se trata de todas las formas posibles de abonar al conocimiento, ¿se puede seguir identificando a unos como investigadores y a otros como investigados, informantes u observables?

Las preguntas en la perspectiva horizontal no responden a las necesidades previamente construidas por un investigador. Se propone que las 
preguntas se construyan en conjunto entre los investigadores que se asocian, identificando lo que ambos consideran central y necesario conocer.

Tuve la fortuna de viajar hace poco a la Sierra Wixárika acompañando a funcionarias del gobierno federal en una visita oficial a la escuela indígena Taatutsi Maxakwaxi. Allí una comitiva de profesores, autoridades tradicionales, padres de familia y alumnos nos recibieron con estas palabras: "Les damos la bienvenida a nuestra comunidad y nos alegra mucho que otros, como ustedes, nos visiten". Más allá de la gentileza de su recibimiento, su discurso mostraba que el concepto otros, ligado a los pobres, a los indígenas, a los marginados de la modernidad eurocéntrica, es una construcción occidental. Tanto ellos son nuestros otros, como nosotros somos sus otros. El lenguaje tiene la opción de ser recíproco, propone en cierto modo formas "vacías" que cada locutor en la práctica comunicativa se apropia y refiere a su persona, definiéndose al mismo tiempo como un yo, y una pareja durante el diálogo como a un tú (Benveniste 1975, 184). El hecho de que el lenguaje crea la categoría de persona tiene efectos muy variados; en la investigación hegemónica al crear un yo investigador y un otro investigado, se nombra un sujeto que conoce y un sujeto que puede ser conocido. El reto para la PHC es horizontalizar el proceso para que el lenguaje sea expresión de equidad y que ambos interesados en las respuestas a los problemas sociales participen como investigadores pares.

En la práctica, las preguntas que se generan con métodos horizontales tienen que ver con el interés investigativo de ambos investigadores. En otras palabras, el proceso de investigar se inicia con el otro, en diálogo con los propios intereses investigativos. Para que los participantes de la investigación transformen su contribución, la identidad hegemónica debe cambiar. El investigador no se posicionará como autoridad, ya que los antes nombrados investigados serán los investigadores pares. Producir horizontalmente conocimiento tampoco significa enseñar al otro los métodos propios de la investigación. Al nombrarnos "pares", queda claro que cada uno conoce una parte del problema, una dimensión de lo que se estudia, y que hay algo que el otro sabe y yo no sé, que juntos podemos hacer las preguntas que, desde nuestro contexto, descubrimos como importantes. 
Para construir la horizontalidad, ambos investigadores deben participar desde sus lugares de enunciación, cada uno debe exponer con claridad sus propósitos. Ambos plantean su visión propia, construida desde múltiples factores teóricos y contextuales, y al ponerlos en común se definen uno frente a otro examinando las diferencias en la búsqueda de algo nuevo. Pensar con el otro es la única manera de generar preguntas que abran nuevas puertas para encontrar formas de vivir mejor juntos.

Hay otro procedimiento diferente a las CCC para aproximarse al otro y es el que hemos explorado en la investigación horizontal de los últimos años con el pueblo wixárika. La demanda o la falta de ella no han sido el freno para construir conocimiento. He partido del supuesto que la demanda está siempre presente en las relaciones humanas. Pero la demanda adquiere otro sentido cuando uno de los investigadores se plantea la necesidad de investigar con un otro investigador. El investigador académico puede tener una inquietud generada por múltiples factores de su entorno y el investigador par tiene las suyas, que pueden o no coincidir para llegar a construir preguntas que generen conocimiento nuevo. Las preguntas de esta manera buscan generar conceptos para nombrar desde varios lugares, los problemas a investigar.

A diferencia de la investigación CCC, en la PHC no se construyen las preguntas desde el investigador legítimo. Tampoco, como en la investigación-acción, se construyen las preguntas a partir de las necesidades de las comunidades observadas desde la perspectiva del investigador participativo, ni se pretende que el investigador observe y recoja cuáles son las necesidades del otro y deje de lado sus propias inquietudes; se busca que todos los involucrados en el proceso definan qué buscan en la investigación y formulen sus preguntas. Es preciso que todos los implicados sean nombrados investigadores, ya que la igualdad discursiva no es una meta a alcanzar, sino el punto de partida para que nadie sea despojado de lo que sabe para responder a los problemas sociales.

En este sentido, también nos diferenciamos de la "ciencia ciudadana" (Cooper 2018), que si bien incorpora el trabajo de los otros en la compilación de datos, su objetivo está definido por el investigador. Aunque de esta manera se pueden explorar con más amplitud los problemas 
por contar con un número grande de ayudantes voluntarios que aportan datos que de otro modo serían inalcanzables, estas investigaciones perpetúan la CCC con las categorías tradicionales. Hay múltiples ejemplos del valor que tiene la ayuda de los voluntarios, sin ir tan lejos, Darwin recibió más de quince mil cartas de todo el mundo con observaciones que le permitieron producir su conocimiento y descubrimiento individual. La PHC busca enriquecer el conocimiento de la sociedad desde las preguntas mismas que formulan juntos los investigadores pares.

\section{Trabajo colaborativo}

Un ejemplo de trabajo de colaboración entre las ciencias ambientales y las humanidades, y las comunidades afectadas, son los descubrimientos arqueológicos del centro Calakmul y la defensa de la biósfera que lo rodea. En medio de la jungla y completamente cubierta por la maleza, fueron los chicleros en 1925 quienes buscando árboles de chico zapote para extraer su goma, descubrieron la antigua ciudad maya de Calakmul. El registro fue hecho en 1930 por el INAH, encargado a un biólogo que con sus alumnos tesistas mapearon la biodiversidad de la zona y sostuvieron la importancia de defender la zona y reconocerla como reserva natural. El terreno pertenecía a diferentes ejidos, ahora es parte del municipio de Holpechén. Sus habitantes decidieron participar con las autoridades y con los científicos que a cambio les enseñaron las propiedades químicas de la tierra del lugar y las alternativas al "tumba, roza y quema" que por experiencia ya sabían solo daña la tierra. Los campesinos dejaron de cultivar la tierra con estos métodos y sacaron la ganadería de la zona, se dedicaron a la apicultura y a los árboles cítricos que se prestan de mejor manera al cuidado de la selva y a la vida de los campesinos. Hoy los arqueólogos del INAH trabajan en conjunto con la población que cuida el lugar y tiene ingresos como guías de los turistas que visitan los $70 \mathrm{~km}^{2}$ que albergan 525 sitios arqueológicos. Son también los trabajadores pobladores locales del recinto quienes muchas veces guían a los arqueólogos en la interpretación de piezas y figuras que se encuentran en la selva. La Comisión Nacional para el Conocimiento y Uso de la Biodiversidad 
(Conabio), recibe las fotografías y videos tomadas por los comuneros de la fauna y flora del lugar en búsqueda de nuevos especímenes. Estas fotografías han contribuido con información valiosa para hacer observaciones repetibles y comunicables. Algunas veces los científicos de Conabio solicitan a los comuneros que regresen al lugar y den continuidad a los procesos de desarrollo de una planta o transformación de un insecto. Gracias al trabajo transdisciplinario, en Calakmul y sus 723000 hectáreas protegidas como Reserva de la Biósfera, se ha registrado el 30\% de la biodiversidad del planeta (Testimonio de María Elena, comunera y guía de turistas de Calakmul, diciembre de 2018).

\section{Teoría y marco conceptual}

Separar la teoría de la práctica no es el camino de las respuestas emancipadoras. Ejemplos como el EzLN o Cherán ${ }^{5}$-por no hablar que son dos casos mexicanos recientes-, nos dejan ver que sus proyectos autonómicos no estaban planteados de inicio por teorías hegemónicas de izquierda ni de derecha. Sus planteamientos autónomos frente a su condición de exclusión del Estado nacional, son resultado de pensar teórica y prácticamente desde su contexto sociopolítico y cultural propio, y desde luego en diálogo con su contexto histórico. De Sousa (2010) reconoce un des-

5 La lucha armada del movimiento del EZLN duró apenas 12 días del 1 al 12 de enero de 1994, transformándose en movimiento político debido en gran parte a las movilizaciones masivas de la sociedad civil nacional e internacional. En un esfuerzo por recuperar para las comunidades la capacidad de decisión y no dejar la autoridad sólo en manos de los mandos militares zapatistas, en 2003 se constituyó un nuevo nivel de gobierno autónomo conformado por cinco centros conocidos como los Caracoles, que se rigen por normas y prácticas alternativas de autogobierno (Baronnet, Mora y Stahler-Sholk 2011). Por su lado, la lucha de Cherán se hizo visible a partir del 15 de abril de 2011 y desde entonces se mantienen a favor de la construcción de un gobierno autónomo para tomar en sus manos la gestión de su comunidad, defender su territorio, recursos naturales, derechos colectivos y responder ante la violencia de grupos armados. De esta manera cuestionan la democracia, el individualismo y la idea de una sola nación. 
encuentro entre la teoría occidental y las prácticas alternativas, y observa que finalmente las teorías occidentales sirven para legitimar las prácticas comunitarias que se concretaron de antemano y sin necesidad de dichas teorías. Éstas sirven muchas veces para otorgar un lenguaje occidental a las prácticas propias y hacerlas más comprensibles a los interlocutores hegemónicos. Porque finalmente la comunicación no es posible salvo cuando se comparten las "palabras" entre quienes desean escucharse.

En la investigación sobre el concepto y uso político de la etnicidad en la Organización Nación Purépecha (ONP), Sandra Nadezhda Martínez (2009) analizó los documentos políticos de la organización y encontró que este movimiento tiene antecedentes donde se ha transformado el discurso, así como los objetivos de la lucha indígena, es decir, que conceptos propios y ajenos se combinan en la elaboración de las nuevas definiciones respecto a los sujetos indígenas y sus movimientos. Los argumentos purépechas de la tenencia de la tierra y su derecho a conservar su lugar son permanentes, sin embargo, hoy su lucha se expande a la etnicidad y su reconocimiento, criticando a la modernidad, a sus ideas "progresistas" sobre la propiedad privada, al mundo occidental y al modelo neoliberal. A continuación se presenta un fragmento del Decreto de la Nación Purépecha (diciembre de 1991), donde se nos ofrece un claro ejemplo del uso del arsenal conceptual occidental:

Para la cultura occidental expresada desde el Renacimiento hasta la época actual de la exaltación del modelo neoliberal y de la clase en poder, la tierra es una mercancía que está sujeta al libre mercado, hoy en su máxima expresión, es un objeto de trabajo y medio de lucro que se debe y puede vender al mejor postor. Esta misma visión occidental concibe como el mejor modo de apropiación y disfrute de la tierra a la propiedad particular, es decir, la propiedad privada (cit. en Martínez 2009, 50).

Rufer (2012a, 76) explica críticamente el debate intelectual en torno al concepto de "los oprimidos" y subraya la distancia entre su significado en la academia y el significado para los etiquetados así. Es de especial interés para nosotros su encuentro con don Efrén y su apropiación 
estratégica del concepto cuando comprende que sólo de esta manera puede acceder a la escucha de quien detenta el poder y el concepto:

Nos llaman los oprimidos. Eso decía un libro. Que palabra fea ¿no? Me suena a los aplastados. [...] Pero la otra vez cuando vino el diputado este...el que ganó, el radical. Yo le dije: "Oiga, es que acá somos los oprimidos”. ¡Uy!, no sabe cómo me miró y me abrazó y me dijo: "Esto se va a acabar". Y yo dije: "Y, bueno, será que hay que decirlo así”.

El paradigma teórico normativo de las CCC propone los patrones de racionalidad donde debe converger todo el conocimiento, independientemente de su contexto. Se ofrecen plataformas "neutras" y homogéneas desde donde se pretende nombrar el conocimiento, pero se olvida que la diversidad de los lenguajes es lo que media nuestro saber. La teoría en las CCC siempre está a la búsqueda de vocabulario definitivo para nombrar lo que ve, sin embargo, pocas veces considera que participar de un universo lingüístico es entenderlo de forma particular y de acuerdo con ciertas reglas contingentes.

Nos surge la siguiente pregunta: ¿qué dejamos de conocer si no aprendemos los otros conceptos que guían a la reflexión y a la acción? La traducción hecha a conceptos teóricos occidentales puede servir a la comunicación con el poder, pero al revés, ¿qué de las otras teorías se traduce para construir verdadero diálogo? Si partimos de que el conocimiento se crea a partir de un contexto y que la pretensión de una única vía universal es sólo una fantasía, ¿cómo construir una red de relaciones contextuales para comunicar los diferentes espacios culturales y las maneras diferentes de entender los fenómenos sociales, si no conocemos otras teorías y marcos conceptuales?

La propuesta de métodos horizontales surge de nuestra propia experiencia y se basa en que la teoría y la práctica son parte de un mismo proceso. Consideramos que el proceso investigativo y de producción de conocimiento es muy complejo, y que no necesariamente los conceptos teóricos anteceden a la práctica y determinan su contenido. Es sintomático que sea un principio del eurocentrismo científico el que la teoría sea concebida 
como abstracción separada de los datos y que el conocimiento científico sea incompatible con la producción de saber desde el conocimiento de los fenómenos cotidianos y tradicionales no occidentales. El separar la teoría de la praxis no sólo acarrea la dificultad de encarar nuevos desafíos políticos al no teorizar sobre la práctica, sino que también desvaloriza el otro conocimiento al momento de distinguir qué es ciencia y qué no lo es.

\section{Saber alimentario y autonomía}

Los proyectos gastronómicos de autonomía coca permiten observar otra dimensión del proceso de reetnización que se está llevando a cabo en Mezcala. Esto es, la construcción de un cuerpo coca a partir de las prácticas alimentarias y los discursos patrimoniales. La historia oficial y la historia relatada por los comuneros de Mezcala concuerdan en un punto: los indios que lucharon en la guerra de Independencia, atrincherados en la Isla de Mezcala, sufrieron hambre, frío y una serie de epidemias, y a pesar de todas estas contrariedades, resistieron heroicamente durante cuatro años a los embates de los españoles. Tanto la historia oficial como la local retratan a los indios de aquellos tiempos como debilitados por el hambre pero con un ímpetu y una resistencia inauditas.

[...] En el discurso de las mujeres que elaboran el recetario coca, los habitantes de Mezcala heredaron la fuerza de los ancestros a través de hábitos alimenticios transmitidos de generación en generación. [...] La idea de comida "sana" y "natural" atraviesa la imagen de la corporalidad coca. La Sra. Susana, cocinera en el restaurante Paraje Insurgente, relata que en el centro médico de Poncitlán, la cabecera municipal, los doctores reconocen inmediatamente a las mujeres mezcalenses por su estado físico: "cuando van a hacer cesáreas dicen [los doctores] que la anestesia no hace efecto a mujeres de aquí, disque porque comen mucho charal y pescado. El doctor llega y dice nomás de vernos sin preguntarnos: ¡ay, ustedes vienen de Mezcala!" (Entrevista 3). Si bien las grandes cantidades de calcio no son referidas por la señora Susana, su discurso vincula la alimentación local con una condición física específica. La Sra. Irma, también cocinera 
del Paraje Insurgente, señala que la diferencia de las recetas coca con respecto a las de los pueblos vecinos, como Poncitlán, Ocotlán y San Pedro Itzicán, es que "aquí la gente no se enferma. Casi no come grasa. El bagre es asado, natural. Se comen chayote, verduras cocidas. No se usan aceites, ni consomé de pollo que tiene mucha grasa. Hasta el huevo lo comemos asado sobre el comal. La sal de grano es el único condimento, casi ni se usan condimentos" (Entrevista 4).

El patrimonio culinario coca no es, por ende, un lugar de refugio, de nostalgia. El proyecto de autonomía coca, formulado en clave alimentaria, articula las nociones de pureza, ancestralidad, fuerza y salud para crear una identidad indígena concebida en términos culturales, políticos y corporales (Bak-Geller, 2019).

Los métodos horizontales entienden el proceso investigativo y la producción de conocimientos como un compromiso político que genera formas de vivir mejor en el espacio público. De esta manera la investigación es considerada como expresión de la vinculación de las teorías con las prácticas del investigador y el investigador par, entre la articulación del conocimiento con lo social y lo político.

Es claro para algunos que investigar siempre implica partir de una serie de teorías convencionales, que necesariamente definen el marco conceptual y por lo tanto lo que será posible "ver" y "entender", es decir, las palabras con las que nombramos el mundo para hacer sentido de lo que nos rodea. Pero otra manera de hacer sentido es buscar nuevos conceptos teóricos que junto con otros amplíen y modifiquen lo que podemos pensar. Estos conceptos construidos en el proceso de la PHC dan forma al nuevo conocimiento sin desatender los contextos históricos y culturales. Estos conceptos conducen de forma diferente nuestra investigación.

\section{Un largo ejemplo horizontal}

Hace unos meses, en una reunión con investigadores pares de la Sierra Wixárika, entendí que hacer una historia dialógica del trabajo que se ha realizado a partir de más de seis mil fotografías tomadas por los jóvenes 
wixaritari durante 20 años, por muchos motivos no sería lo mismo para ellos y para mí, pero que juntos podríamos aportar conocimiento sobre la visualidad permeada por la tecnología de la imagen. Por ser un caso excepcinal, este archivo de fotografías tomadas en dos contextos históricos diferentes, compacta en sólo 20 años la transformación visual que ha experimentado una gran parte de la población global a partir de la penetración de las imágenes en la vida diaria.

Empiezo por relatar los procesos de interacción que conforman este camino. Fue en 2016, durante un evento académico de especialistas del norte de Jalisco y sur de Zacatecas, donde por casualidad me topé con un joven wixárika universitario. El joven me planteó la necesidad que veía de "completar nuestra historia visual". Me dijo: "tienes las fotos que sacaron los alumnos de Tatutsi Maxakwaxi hace años, pero ahora han cambiado mucho". Agregó: "hoy tienen celulares y con ellos se toman cantidad de fotos, son muy diferentes y falta verlas también". El joven, desde su primer contacto conmigo, aludía ya a una historia conectada: la de su cultura visual y la de la tecnología de la mirada occidental y globalizada.

Rescato de esta rápida conversación el concepto de historia como primer reto para responder a la pregunta planteada por el joven wixárika. Años antes, durante una evaluación escolar en la secundaria Tatutsi Maxakwaxi, me había topado entre profesores y alumnos con un concepto de historia que no privilegiaba las fechas ni ordenaba los acontecimientos en una línea recta, los hechos se mencionaban como relevantes por su repetición y actualidad. La misma línea del tiempo como formulación de la historia, y que se aprende como concepto desde la escuela primaria, es diferente a la línea curva que me mostró con la mano mi joven interlocutor mientras me sugería la tarea de "nuestra historia visual".

Por el mismo tiempo, Jorge, un padre de familia wixárika, me había comentado la inconformidad que tenía con quienes pretendían escribir su historia: "los teiwari vienen y nos dicen que vamos a desaparecer, que contemos nuestra historia para que ellos la escriban y así permanezca". Después señaló lo siguiente: "yo voy a morir, pero los que ahora son niños van a seguir, ellos están aquí [presentes] para que aprendan y lo hagan ellos después". 
El concepto occidental de historia está ligado a la escritura, en cambio para los wixaritari lo escrito no es la propia historia. Carlos Salvador, el director de la escuela, me había aclarado: "México es una ciudad muy grande, con mucha gente, muchos coches, mucho humo... nosotros no somos mexicanos"; explicó que no se reconocen en la mexicanidad de la historia nacional escrita, donde aparece que aztecas y españoles fundaron la nación. "Ser mexicano para los wixaritari, no existe. Existe kiekame, que quiere decir nativo de esta tierra, porque aquí vivieron mis antepasados, mis abuelos, mis padres; aquí es donde trabajaron, donde sembraron maíz, calabaza y frijol" (Corona et al. 2007, 65).

\section{Historias otras}

Se observaron tres tipos de respuestas a la pregunta: “¿cuál piensas que es el momento más importante en la historia de los indígenas?":

1) Las respuestas menos comunes contestaron con casos concretos como la historia de Huetákame, la guerra en la sierra entre los indígenas, la invasión de los españoles que obligaron a los indígenas renunciar a su cultura, a la fiesta del maíz y al peyote.

2) Las respuestas más frecuentes no se refieren a "momentos", sino a una historia continua, con origen en sus antepasados y presente el día de hoy: lo más importante es "nuestra cultura, nuestras costumbres, nuestra vestimenta, nuestra lengua, creencias, comunidad, tierras, cultivos, fiestas, alimentos". La historia occidental separada en fragmentos, no parece coincidir con su percepción. La expresión de su propia historia se manifiesta desde los "antepasados, nuestros dioses, los sabios". Ellos dicen "llevan la cultura", en otras palabras la historia no son datos que se memorizan y repiten, es algo que se vive y se "lleva" puesta (en "nuestra vestimenta, nuestras fiestas, nuestros alimentos", etc.). En coherencia con las respuestas anteriores, "vivir con armonía" se menciona en repetidas ocasiones como "lo más importante de la historia".

3) En tercer lugar se encuentran las respuestas que se refieren a circunstancias políticas: "cuando se reconocieron los derechos de los indígenas, cuando se declararon leyes, cuando se respetó a los indígenas, cuando se les permitió elegir a sus gobernantes, ser libres, tomar 
sus 'propias decisiones"'. Es de notar que en sus respuestas recuerdan las convenciones, contratos, leyes, consensos y acuerdos de soberanía pero no mencionan las luchas, guerras, invasiones y conflictos.

Con relación a la historia oficial de México y a las fechas que se celebran nacionalmente (15 de septiembre, 20 de noviembre, 5 de mayo, 24 de febrero), se mencionan en contadas excepciones, no se conoce lo que se celebra y tampoco la relación de las fechas con su propia historia (Evaluación del Bachillerato Intercultural Tatei Yurienaka, Fundación Ford, agosto de 2008).

De esta manera se desmitifica la historia escrita como la probabilidad de mantener un recuerdo más veraz del pasado. Me inclino por observar con Ángel Rama (2009), que la escritura ha servido sobre todo para poner un orden social y dominar a partir de una ciudad letrada donde se ejerce el poder a través de la escritura. Los wixaritari entienden este recurso. La primera vez que llegué a San Miguel Huaixtita, el mismo profesor Carlos Salvador planteó la necesidad de hacer un intercambio entre el permiso para visitar su comunidad y la impartición de clases de español para profesores y alumnos, esperando que aprendieran a hablar español "para defenderse" precisamente de gente como yo. Además de entender que investigar tiene que ver con reciprocidad, aprendí que el lenguaje escrito servía a otros fines que no eran los de registrar su propia historia.

Lévi-Strauss $(1992,323)$ también hace notar la función de la escritura altamente valorada como registro cuando se piensa que:

podría concebírsela como una memoria artificial cuyo desarrollo debería estar acompañado por una mayor conciencia del pasado, y por lo tanto de una mayor capacidad para organizar el presente y el porvenir. [...]

Sin embargo, nada de lo que sabemos de la escritura y su papel en la evolución humana justifica tal concepción. Una de las fases más creadoras de la historia se ubica en el advenimiento del neolítico: a él debemos la agricultura, la domesticación de los animales y otras artes. Para llegar a ello fue necesario que durante milenios pequeñas 
colectividades humanas observaran, experimentaran y transmitieran el fruto de sus reflexiones... en una época en que la escritura era aún desconocida. [...] Inversamente, desde la invención de la escritura hasta el nacimiento de la ciencia moderna, el mundo occidental vivió unos cinco mil años durante los cuales sus conocimientos, antes que acrecentarse, fluctuaron. [...] En el neolítico, la humanidad cumplió pasos de gigante sin el socorro de la escritura.

Ahora bien, regreso a hablar del concepto de historia en la lengua del pueblo wixárika y su aporte al "tercer texto" en la PHC. Este concepto no está relacionado con la escritura sino con el cuerpo mismo. Yeiyari es la palabra wixárika para nombrar la caminata que se realiza de un punto a otro y que tiene una relevancia especial. Yeiyari funciona también como el concepto de historia, que no tiene un equivalente en la lengua y la cultura wixárika. Desde nuestro lenguaje, carecemos de una palabra que exprese la historia desde un movimiento del cuerpo, permanente y dinámico. En esta investigación horizontal, adoptar el concepto wixárika y pensar la historia como un yeiyari nos recuerda que el paso del tiempo, el transcurso de un punto a otro, es un recorrido en el que caben sucesos, ideas, transformaciones, pero en el que nunca está ausente el cuerpo. El yeiyari es un concepto que aporta al nuevo conocimiento de nuestra visualidad, ya que, a diferencia de la historia, deja ver las huellas del tiempo y el espacio en el cuerpo mismo.

Según se tiene noticia, ningún joven wixárika de San Miguel Huaixtita había tenido acceso a una cámara fotográfica antes de abril de 1997. En ese año, provistos por vez primera con cámaras de un solo uso, los jóvenes descubrieron la fotografía, decidieron qué era digno y apropiado de fotografiarse y cómo querían capturarlo. Veinte años después, en 2017, otra generación de la misma escuela repitió la experiencia: 100 jóvenes tomaron de nuevo 2700 fotos con cámaras desechables. ${ }^{6}$

6 El archivo de fotografías de Taatutsi Maxakwaxi se compone de 2700 tomadas en 1997 y 2379 tomadas en 2017. El total son 5079 fotografías. La diferencia en el número de fotos por sesión fotográfica responde a diferentes prácticas fotográficas de los jóvenes. Si bien en 1997 y 2017 se repartieron 100 cámaras de un solo uso y de 27 tomas cada 
En los dos grupos de fotografías realizadas con veinte años de distancia se puede apreciar que el cuerpo se transforma de muchas maneras: por una parte, en el contenido de las fotos, las personas fotografiadas son distintas, las modas de sus vestimentas cambian, sus poses y gestos son diferentes, y mudan los escenarios de fondo que son la naturaleza, la arquitectura y el pueblo.

Por otra parte, ha cambiado también la mirada del fotógrafo que observa el mundo. Mientras que las fotografías de 1997 mostraban consistentemente escenarios completos y planos amplios, hoy, después de su experiencia con imágenes de la televisión y los celulares, las fotografías son diferentes. En las tomas más recientes, la naturaleza como contexto desaparece y, por el contrario, las caras cubren toda la superficie de la imagen. La amplitud, el contexto y la profundidad de campo que observábamos en las fotos de otros tiempos, hacen lugar a la centralidad indiscutible de los sujetos.

El año de 1997, fecha en la que inicia el yeiyari de la fotografía wixárika, coincide con otro acontecimiento en la historia de la fotografía, esta vez de carácter global. En dicho año, Philippe Kahn creó el primer teléfono móvil con cámara fotográfica capaz de enviar fotos de forma inalámbrica. Este diálogo con las fotos, al mostrarnos cómo veían los jóvenes wixárika antes y después de la aparición de los teléfonos celulares, las imágenes ubicuas y los selfies, nos permite pensar en la transformación de nuestra propia mirada, en un recorrido paralelo.

Este acervo es también de gran significado para la comunidad wixárika. En el transcurso de 20 años se revela una caminata íntegra, desde sus primeras fotos hasta las tomadas después del teléfono celular. Las fotografías son un testimonio personal, y por eso están acompañadas por un comentario de los propios fotógrafos en el que relatan su intención y su

una, en 1997 se pudieron rescatar el 100\% de las fotografías que la tecnología permitía, mientras que en 2017 el interés menor puesto en estas "camaritas" se evidenció en la pérdida de algunas de ellas, la entrega de las cámaras para su revelado sin agotar el rollo o el descuido con el que se tomaron algunas imágenes que no se revelaron. 
experiencia. Pero las fotografías constituyen más que recuerdos personales: son una muestra de la vida dinámica de los wixaritari. ${ }^{7}$

Los fotógrafos wixaritari parecen decir que su cultura se construye de manera concreta en la relación con el otro, pero no como un procedimiento donde ellos busquen la pureza, la diferenciación o la exclusión, sino como un proceso dinámico donde se conectan a la propia identidad elementos ajenos que dan respuesta a nuevas necesidades. Sus ropas, sus gestos, sus fotos y su lenguaje son distintos al de sus antecesores. Desde su lugar, no hay wixaritari contaminados o a medias ni en vías de desaparición. Los wixaritari probablemente han sobrevivido porque su historia es la de un diálogo permanente.

El yeiyari nos ha permitido hacer otras lecturas del mundo, que en la confrontación con el otro, en espacios de intervención horizontal, se pueden hacer explícitas.

\section{Métodos y procedimientos}

En la lengua wixárika no existe una palabra exclusiva para decir "investigación". En la búsqueda con los profesores de la escuela Taatutsi Maxakwaxi por hallar un sinónimo, encontramos una expresión que se acerca en su lengua a la actividad que podíamos realizar para producir conocimiento en torno a los problemas que nos interesan. Este concepto es: ne kenem + reitimait+ yeika o "como yo lo entiendo".

Este concepto desafía el sentido occidental de ciencia. En sus principios y técnicas empíricas, en su afán de buscar la verdad y vigilar la objetividad, la CCC busca que el sujeto desaparezca, que no contamine el entorno, que no muestre su particular sentir o entender. Para los wixaritari, construir conocimiento o investigar es llegar a formular "como yo

$7 \quad$ Son los investigadores pares los que en horizontalidad analizan el contenido de las fotografías. Cada analista escogió 2 fotos, una de cada momento histórico. De esta manera cada foto cuenta con el texto del fotógrafo en el momento de hacer su foto, de un participante wixaritari 20 años después y de la propia investigadora par académica. 
lo entiendo", destacando al sujeto investigador, su contexto y el entendimiento que reposa en su teoría y su praxis.

El concepto investigar, o ne kenem+ reitimait+ yeika, en lengua wixárika sabe afrontar el conflicto generador y pone a prueba el diálogo entre sujetos distintos. Entender que investigar es "como yo lo entiendo", es reconocer la condición de enunciación de los sujetos y que existen diferentes maneras de construir conocimiento.

La observación, la encuesta, la entrevista y las múltiples técnicas que se desprenden de las CCC para pretender apropiarse del conocimiento del otro, conllevan la certeza de que bien aplicadas nos liberan de engañosas apariencias. Pero sabemos que no es más que un deseo, un "confort metafísico" según Rorty (cit. en Oliveira 2013), la fantasía de ver, como Dios, sin ser observado.

Los problemas de investigación y sus soluciones los heredamos con los conceptos teóricos. En nuestro proyecto metodológico para las ciencias sociales y culturales, una teoría única como armazón para estructurar nuestro pensamiento en una sola dirección sólo oculta nuestra condición humana diversa y contextual. El contexto se vuelve central en la construcción metodológica, no es una racionalidad única y eurocéntrica la que define los procesos, sino que estos se definen de acuerdo con todas las formas racionales implicadas en los procesos de investigación, sin otorgar superioridad a una sobre otras. En diálogo se busca dar respuesta a los problemas y a los temas que nos afectan. La horizontalidad implica que en el diálogo participan dos o más sujetos a partir de su palabra y razón.

Ser horizontal entonces significa abrirse a las razones de los demás, que pueden ser muy distintas. Las otras maneras de educar, de curar, de pensar los lenguajes formales, y que incluyen dimensiones que ponemos en otros lugares, nos hace preguntarnos cómo podremos convivir sin producir juntos nuevas maneras de investigar.

\section{Matemáticas mayas}

La investigación muestra que existe una relación entre las prácticas sociales vivenciadas por la comunidad maya Q'eqchi' con algunos 
procesos matemáticos de contar, calcular y medir; y éstos son utilizados en distintos niveles de profundización y apropiación, que generalmente son determinados y marcados por factores que fomentan y/o deterioran el uso del sistema de numeración vigesimal. [...] Con esto se puede decir que el sistema vigesimal no solo es importante para cuantificar los bienes materiales, resolver situaciones-problemas y conservar la cultura sino que también para manifestarse espiritualmente. En esta investigación se evidenció que las prácticas más ligadas al uso del sistema vigesimal es el cultivo del maíz y ceremonias espirituales que se realizan en las comunidades, otorgándole un sentido particular al sistema de numeración vigesimal y trecenal, sobre todo cuando se toma en cuenta el calendario maya y su relación con el nawal de las personas. [...] El pensamiento de los mayas ofrece la posibilidad de un acercamiento a concepciones distintas y extraordinarias sobre el concepto del tiempo. La persona es un ser temporal por excelencia, porque viviendo en el tiempo, tiene una conciencia de ello y en un momento de excepción descubre que hay en esto más de un misterio (Yojcom 2013).

A este respecto, Bajtín observa que la función del otro no es de contraste donde un yo se opone a un tú, sino que el sujeto es social precisamente porque es un fenómeno dialógico en el que el otro es parte constitutiva del ser. La dialogicidad como constructora del sujeto se puede entender a partir del lenguaje: soy yo porque existes tú. De esta forma estamos frente a una subjetividad construida con la alteridad. De una segunda manera soy siempre en relación al otro, el discurso propio se refiere y responde al discurso del otro y a su vez se formula anticipando su respuesta.

Así el discurso del otro me mira, me valora y me define, y también me devuelve un excedente de mí, esa parte que yo no puedo ver salvo a través de su mirada. Tampoco una cultura puede completar su identidad sin conocer su imagen en el espejo de la otra cultura. Investigar significa entonces promover el encuentro con el otro para alternar las miradas y proporcionar una visión más integral de ambas culturas. 


\section{Análisis e interpretación}

Ver y no ver suceden al mismo tiempo; la mirada no es exhaustiva, cuando algo no tiene nombre, se escapa de nuestra vista. En estos casos, otro que mira contribuye a ampliar el propio enfoque. Bien dice el rezo popular cuando se busca en vano algo que, a pesar de tenerlo delante, no lo descubrimos: "Préstame tus ojos, para con ellos mirar". En la investigación complementar la mirada propia, convencional y disciplinada por las reglas del hábito, con la mirada del otro, sirve para ubicar lo antes no visto y transformar así el propio entendimiento.

En otras palabras, en la PHC confrontamos la autoridad de la etnografía y de la observación, cuestionamos la mirada del investigador como la única autorizada para interpretar mundos que con otras palabras ven y nombran. Poner en sus manos, mejor dicho, en sus ojos, la autoridad para ver, clasificar e interpretar el mundo que le pertenece a otros, nos parece que empobrece los resultados de la investigación social. Restrepo $(2016,25)$ critica la etnografía y la observación como herramientas de análisis e interpretación legitimadas por la mirada etnocéntrica de los investigadores que no consideran los conceptos otros.

Esa arrogancia cultural del etnocentrismo es fuente de ceguera para la investigación etnográfica. No es posible comprender y justipreciar aspectos del modo de vida de una cultura distinta de la propia ante la cual se tengan posiciones etnocentristas. La etnografía no busca juzgar ni mucho menos ridiculizar la diferencia; lo que busca, al contrario, es comprenderla en sus propios términos. De ahí que mientras el etnógrafo no haya cuestionado y tomado distancia de sus concepciones etnocentristas y se tome en serio la importancia de relativizar sus propios valores culturales, su labor etnográfica estará marcada por tales concepciones apocando significativamente su capacidad de comprender densamente la diferencia cultural a la que se enfrenta.

Sin embargo, el autor no deja de confiar en la reflexividad del etnógrafo y la seriedad con la que se tome el trabajo, y no cuestiona el 
lenguaje limitado del investigador para poder reconocer aquello que es nombrado por otras palabras. Consideramos que el asunto no es educar la mirada del antropólogo para reconstruir el régimen de pertenencia del otro y lograr el conocimiento objetivo, más bien se trata de desarraigar el problema de los imperativos de la objetividad y la exhaustividad para ubicarlo en el ámbito de la comprensión dialógica.

Lo que Bolívar Echeverría $(1997,61)$ llama poner la identidad en estado evanescente, nos puede ayudar a entender esa mirada complementaria que sólo otro nos ofrece. Esa identidad que "cuando al invadir a otra, se ha dejado transformar por ella o cuando, al ser invadida, ha intentado transformar a la invasora. Su mejor manera de protegerse ha sido justamente arriesgarse". En otras palabras, analizar para producir nuevo conocimiento, significa poner en crisis lo propio frente a lo que el otro sabe, "arriesgándose" para construir algo nuevo.

\section{Nuevos textos}

Según Guillermo Bonfil Batalla, la apropiación es el proceso mediante el cual el grupo adquiere capacidad de decisión sobre elementos culturales ajenos y es capaz de producirlos y reproducirlos. El proceso de apropiación culmina y los elementos correspondientes pasan a ser elementos propios (Bonfil Batalla 1988, 15). En el caso del bordado huichol, la apropiación actualizada es una versión particular de una propia forma cultural con las representaciones de otras culturas. En las comunidades huicholas podemos encontrar no solo temas y muestras "tradicionales" o méripai mieme, una palabra que usan las bordadoras para referirse a las cosas tradicionales que tienen su origen en la cultura huichola y que han existido y se han usado antiguamente en la comunidad. También se encuentran las cosas nuevas y no "tradicionales", que no se haya usado antes en la comunidad, que llaman "modernas" o, hiik+ mieme. En la confección del traje bordado se pueden observar cómo se fusionan las ideas hiik+ mieme con las formas méripai mieme de la propia cultura. Los huicholes, aun los más tradicionales, utilizan los elementos de otras culturas con flexibilidad. Esta es una propiedad del traje bordado actual en 
San Andrés Cohamiata, Jalisco. El uso de los elementos hiik+ mieme no implica la degeneración de la "tradición". En el contexto del mercado que rodea a la comunidad, las bordadoras se convierten en los sujetos del cambio. Ellas descomponen la relación entre lo propio y lo ajeno y reconstruyen su identidad social. De esta manera las bordadoras son negociadoras dialógicas. Por esa particularidad, el traje bordado huichol ha sobrevivido hasta hoy (Mizuno 2012).

Por el contrario, el análisis y la interpretación desde las CCC implica proporcionar una "cadena coherente de razonamientos para eliminar las interpretaciones contrarias". En otras palabras, se recomienda traducir aquello que se investigó a un lenguaje científico preestablecido y que tenga una aplicación universal. Frente a una idea esencialista de las representaciones y de acceso inmediato e infalible a la realidad, que posteriormente se interpreta a partir de una racionalidad privilegiada, consideramos que la investigación que genera horizontalmente conocimiento tiene que ver con una práctica social que se define por las reglas que su contexto le dicta y que poniendo en pausa su propio conocimiento, busca aprehender con otros para producir nuevo saber compartido.

Contra una sola razón legítima o la "razón arrogante" como Carlos Pereda nombra a la ciencia que se limita a la búsqueda de conocimiento universal, en este lugar el conocimiento es precisamente una práctica posible porque somos miembros de una comunidad lingüística y de saberes que se pone en crisis, en pausa, evanescente frente a las razones de los otros. En PHC buscamos que las múltiples razones se exhiban y dialoguen, porque no hay lenguajes y por lo tanto tampoco saberes superiores e inferiores, y las nuevas respuestas surgen en el análisis y la interpretación a partir de todos los implicados en el problema social.

Interpretar y analizar significa finalmente traducir, según Barthes, Foucault y Steiner. Al analizar horizontalmente no sólo se descifra, también se crea algo nuevo. Este hecho nos hace cuestionar las interpretaciones digitales hechas por los programas computacionales y los modelos estandarizados, pues toda traducción literal es imposible o es inteligible: "La indagación que solo repite, cita o reproduce lo dicho por 
los sujetos no permite el traslado del sentido para su mejor comunicación y comprensión" (De la Peza 2012, 207).

En PHC no será un análisis que deje ver lo que le falta o le sobra a una de las partes, siendo generalmente en estos casos la versión occidental el referente. No será tampoco un análisis comparativo que nombre los universales y por oposición los usos y los significados diversos, considerados fortuitos; ni tampoco será una descripción regional o monográfica de la cultura del otro. Proponemos una interpretación conectada que pueda ayudar a entender los hechos sociales más allá de las miradas monoculturales de un solo investigador, para construir un nuevo conocimiento en el que cada uno sea reconocido como legítimo. En este caso analizar se refiere a conectar las múltiples relaciones entre las distintas interpretaciones.

Traducir, interpretar y recrear en la etapa del análisis horizontal produce algo nuevo que llamamos un "tercer texto". La diferencia de este resultado con el hecho de hibridar, ${ }^{8}$ mestizar o combinar visiones, está en que la fusión anula la visibilidad de las diversas colaboraciones y la "mezcla" deja fuera precisamente el aporte de cada una. Por ello, recurrimos a otra metáfora, el tercer texto con miras a abandonar la perspectiva naturalista que insinúan las anteriores. Con tercer texto entendemos la producción que se realiza en diálogo, donde al hablar-dialogar con otros, necesariamente se modifican los lenguajes para llegar a comprender. La condición del tercer texto en este sentido es propia de lo nuevo, de los múltiples lenguajes humanos, cuya convivencia conflictiva generadora puede ser productora de nuevas respuestas a las preguntas sociales.

Si la identidad cultural deja de ser concebida como una sustancia y es vista más bien como un "estado de código" [...] que vuelve usable,

8 Valenzuela (2014, 30-36) ofrece una explicación histórica del término "híbrido", utilizado con frecuencia con relación a la cultura. Explica que el término hibridismo cultural, con origen en los estudios de genética, fue acuñado por Kroeber en 1923 destacando la existencia de culturas híbridas en todas las situaciones donde existe contacto intercultural. Es el libro Culturas Hibridas de García Canclini (1990) el que dio fuerza al concepto para explicar los cruces culturales de lo tradicional y lo moderno, y así cuestionar los esencialismos identitarios. 
"hablable", a dicho código-, entonces esa "identidad" puede mostrarse también como una realidad evanescente, como una entidad histórica que, al mismo tiempo que determina los comportamientos de los sujetos que la usan o "hablan", está simultáneamente, siendo hecha, transformada, modificada por ellos (Echeverría 1997, 74).

Las contradicciones que aparecen en el proceso del análisis realizado entre múltiples voces no son consideradas amenazas que deben ser eliminadas como "ruido" o como "opiniones" no autorizadas, más bien son insumo para explorar, formar el tercer texto y enriquecer el conocimiento. Descartar lo que se considera impertinente, cierra las puertas a lo nuevo y a la horizontalidad. A partir del conflicto generador, la posible contradicción promueve la exploración de la diversidad y alimenta el conocimiento que es siempre provisional.

\section{Publicación y crítica}

La diseminación del conocimiento debe también contar con el diálogo entre los participantes, por ello la autoría de los textos aparece como un tema que debe ser discutido en los mismos términos que la investigación. Con la intención de aportar a la creación de una modalidad discursiva que muestre el diálogo en la construcción del conocimiento, hemos propuesto una autoría entre voces (Pérez-Daniel y Corona 2007; Pérez-Daniel 2012; Corona y Kaltmeier 2012; Corona 2016), que en este lugar se actualiza a la luz de nuevas autorías horizontales.

\section{Orden textual}

En la comprensión que la dialogicidad, reciprocidad y horizontalidad son principios de las metodologías horizontales, es que consideré contradictorio el escribir una tesis que aplazara el hablar sobre los educadores patrimoniales y el referir las palabras que me compartieron en el diálogo e interacción con estos, hasta los llamados capítulos de resultados dentro de un formato académico que divide 
en compartimentos lo teórico, metodológico e interpretativo. Con este orden, omitiría cómo el encuentro con estos sujetos ha transformado mi mirada sobre el fenómeno de la educación patrimonial en los museos y relegaría su papel como portadores de conocimientos durante el proceso de la investigación.

También me pareció contradictorio el desarrollar un texto con una estructura que, en primera instancia, refiera a los autores validados por la academia, mientras que en segunda, a los sujetos con los que se investiga y hasta de quien investiga. En su lugar, consideré pertinente colocar en un mismo plano las distintas voces que se involucran en la investigación en un ejercicio que les hiciera confluir a modo de un diálogo que se otorga en referencia a la educación patrimonial en los museos.

Para finalizar, el referir e interpretar a los educadores patrimoniales con quienes investigo desde el inicio de la tesis, respondió a la conveniencia de escribir y leer un texto que tenga unidad entre sus partes. Un texto en el que no tuviera que postergar el escribir sobre los saberes compartidos por los educadores patrimoniales que participan en la investigación y donde el lector no debe esperar hasta casi el final del documento para conocer éstos (Pérez 2019).

Publicar horizontalmente significa dejar ver la autoría de cada participante, a diferencia de la autoría de la CCC que promueve la objetividad y hasta donde es posible oculta las condiciones de enunciación de todos los que aportan al texto que se presenta al lector. No es extraño encontrar publicaciones firmadas por varios autores participantes generalmente en investigaciones que se realizan en los laboratorios y en prácticas experimentales donde los equipos de trabajo, liderados por un investigador principal, realizan el estudio y posteriormente publican sus resultados. Sin embargo, la lista indiferenciada de autores de un texto muchas veces oculta la jerarquía discursiva o niega la participación de algunas voces durante el proceso de construcción del conocimiento. En este tipo de modalidades de autoría conjunta, tampoco es visible que el discurso propio siempre es frente a otro y que este otro define el discurso mismo. Desde nuestra perspectiva, diálo- 
go significa exhibir lo propio sin que medie un texto posterior combinado de tal manera que no permita reconocer la voz de cada uno de los autores.

En las ciencias sociales y las humanidades, esta particularidad es especialmente relevante. Compartir públicamente los hallazgos de una investigación implica que además de describir los datos, la escritura misma construye los resultados. Autores como Barthes y Bourdieu han discutido el hecho de que la escritura, y no las amplias descripciones factuales, es la que aporta conocimiento sobre lo social. Uno de los argumentos es que el autor necesariamente reescribe la oralidad, el gesto y la imagen, y lo traduce al informe escrito. En nuestro caso, los autores de forma horizontal definen la significación del hallazgo.

El nombre del autor no pasa por desapercibido en la portada de un libro, los créditos de una película o una exposición fotográfica. En la cultura occidental éste se posiciona como dueño de la obra, gana dinero, prestigio y reconocimiento como creador, pero su quehacer es finalmente como el de un artesano que en una obra "acomoda las palabras" y los saberes de su contexto. Quizás pueda parecer natural que así sea, pero es una paradoja que el autor occidental firme como suyo un conocimiento que de hecho surge del "campo", del entorno disciplinario y las condiciones sociales de la investigación.

En el contexto indígena se comprende esta contradicción y se cuestiona el concepto de la autoría individual, alegando que lo que se escribe siempre surge de la cultura y ésta es una producción colectiva. En mi primera experiencia de escritura conjunta con indígenas wixaritari, en Nuestro libro de la memoria y la escritura (2002), mientras el profesor Agustín Salvador dictaba sus clases de cultura wixárika, se grababan y se transcribían, yo intervenía al proponer ejercicios pedagógicos para trasmitir la cultura de la escritura; los créditos parecían obvios: texto de Agustín Salvador y estrategia pedagógica de Sarah Corona.

Sin embargo, durante la presentación de esta obra en la comunidad de origen del profesor, frente a invitados académicos y autoridades tradicionales, fuimos testigos del juicio que se hizo al autor wixárika por firmar con su nombre una obra que era considerada producto de lo que había aprendido en su cultura. Se le acusaba de intentar hacerse rico 
vendiendo lo que a la comunidad le pertenecía. El conflicto se resolvió con la aclaración de que nadie se hacía rico escribiendo libros y que toda ganancia que generara el libro sería para fomentar la educación de los jóvenes de la comunidad. No obstante, el nombre del profesor Agustín Salvador en la portada le causó contrariedades entre los suyos y, por otro lado, en el contexto académico a mí me dio puntos en el escalafón universitario.

Si bien la autoría científica está ligada al mérito científico y a la ética personal, existen evidencias sobre comportamientos inadecuados en los trabajos de autoría colectiva. Para la CCC pareciera que una reglamentación más estricta en el tema de la autoría colectiva y con la ayuda de programas computacionales, se podrían controlar las diversas formas de plagio científico. Si bien hay textos que discuten y se lamentan la poca incidencia de la regulación en el comportamiento de los autores (Ruíz-Pérez, Marcos-Cartagena y Delgado 2014), en nuestra posición la regulación no es el problema central de la autoría en ciencias sociales, más bien hablamos de otras formas de publicación, que reconozcan la autoría colectiva donde las voces de todos se escuchen, dichas por cada uno y frente a los otros.

En ningún caso el autor es el creador iluminado de la obra. Sabemos que el autor es un "sujeto social" que expresa lo que su situación individual, social e histórica le permite. Se sabe también que el conocimiento no proviene de los datos de una realidad objetiva e incuestionable, y que son los marcos de referencia que el autor posee los que determinan lo visible, lo investigable, lo pensable y lo producible.

De nuevo refiero a un ejemplo de autoría wixárika: en el caso de los profesores wixaritari, el conocimiento se construye a partir de lo que su comunidad les ha trasmitido y ese conocimiento será avalado por la misma comunidad: son los conocedores, los marakames, las autoridades tradicionales y morales de la comunidad quienes determinarán si lo expresado en la obra es o no es verdadero. Para el autor wixárika, lo que valida su palabra es su comunidad, puesto que entienden que es sobre su comunidad de lo que hablan. El autor wixárika narra lo que sabe, lo que ha oído y lo que conoce. No da fechas, ni hace referencias, ni cita otras 
fuentes escritas. La comunidad le ha permitido hablar en su nombre, y eso asegura su relevancia y validez.

La propuesta autoral occidental hace referencia al mundo de la escritura. Para el autor occidental, lo que escribe es suyo siempre y cuando lo valide frente a la academia. Debe probar conocimiento y supuesta autonomía. Citar, dar crédito a quienes lo anteceden, señalar la bibliografía utilizada, ubicarse en el estado del arte, en el conocimiento del género discursivo, etc., son reglas que el lector occidental espera encontrar. En el caso de no respetar estas reglas, el autor será señalado como plagiario. El autor es aval del texto, de la veracidad de lo que se dice y de las fuentes que lo determinan; demuestra que sabe "construir" una obra. No se debe olvidar que la autoría también implica responsabilidad y rendición de cuentas en el momento de su publicación.

La autoría entre voces como la pensamos es parte del proceso investigativo en dos momentos. La construcción misma del objeto estudiado, sus métodos, conceptos, técnicas, etc., son autoría de los investigadores pares. Son en igualdad discursiva quienes construyen desde sus conceptos teóricos y desde su experiencia empírica la forma en que se realizará la investigación. Los investigadores se vuelven posteriormente traductores y productores de explicaciones inevitables para construir conocimiento. La autoría entre voces supone horizontalidad desde el momento de construir el propósito del estudio; los conceptos y las técnicas de allí se desprenden. Como primer momento, el conflicto generador provoca el diálogo que produce investigación conjunta. En el encuentro, al aproximarse al mundo del otro al mismo tiempo que los otros se inscriben en la esfera de sentido del investigador, se construye la comunicación entre ambos.

En un segundo momento nos preguntamos, ¿cómo hacer que aparezcan las múltiples voces de los investigadores, cada uno desde su propia voz? Según Voloshinov (1976), sólo son dos las formas en que en la escritura aparezcan las voces de los otros: como el discurso referido (DR), donde el discurso mantiene su integridad y se forjan límites rígidos entre éste y el autor que refiere, llegando a apreciarse un discurso con un estilo lineal. Propio de este estilo son por ejemplo los discursos jurí- 
dicos y los de la prensa que intentan mostrarse libres de la subjetividad del autor o contexto que refiere (CR). La segunda forma es cuando se infiltra la interpretación y el comentario del autor, se borran los límites entre el discurso referido y el contexto que refiere, y se produce un estilo "personal" donde puede ser más dominante uno o el otro. En estos casos la voz del otro pierde su valor referencial para volverse más o menos decorativo, o bien el CR aparece más activo en el texto. La literatura y las etnografías comparten este estilo.

La manera de escribir "entre voces" se confronta con las dificultades antes descritas del lenguaje y la escritura. Sin embargo, los múltiples bosquejos que buscan publicar las voces de todos los participantes de una forma dialógica, lo van formulando entre el diseño editorial, los textos múltiples que se producen en el proceso de la investigación horizontal y el diálogo con otros materiales como las fotografías, los mapas, los dibujos y las cartas.

Enfrentados a estos dilemas, la autoría entre voces se ha concentrado en producir formas textuales a varias manos, donde se observa que la voz de uno es siempre frente a otro. Rebeca Pérez-Daniel encuentra cuatro procesos diferentes de autoría de textos interculturales: el autor solitario, el autor grupal especializado, el autor grupal en diálogo con la comunidad y el autor grupal en diálogo con el otro autor grupal. Este último es:

un texto polifónico y simétrico en cuanto que ambos grupos de autores participan en el proceso con la misma función, logrando expresar posicionamientos distintos, desde el marco de referencia desde donde se posicionan. [...] Este tipo de autoría fomenta un proceso de enseñanza-aprendizaje crítico, en donde no hay verdad que develar, sino posturas que comprender (Pérez-Daniel 2012, 85).

Un esfuerzo radical es la escritura entre voces de una tesis de grado. Este género textual es especialmente dominado por las CCC y las instituciones de educación superior. En otras palabras, subvertir la regla de autor único, investigador legítimo, sometido al escrutinio de un jurado hegemónico, es un reto determinante. Enfrentada con esta situación, 
Beatriz Nogueira (2019) en su tesis produce un texto polifónico donde dialogan el texto de la partera María Asunción -su investigadora par-, el discurso de otros parteros comunitarios, las investigaciones académicas relacionadas a la partería, los conceptos y discusiones teóricas hegemónicas y sus propias discusiones. La tesis se convierte en un gran texto dialógico, donde se entretejen en la escritura misma de la tesis todos estos textos para producir conocimiento horizontal. Coincido con Clifford Geertz $(1997,16)$ cuando señala que los autores deben "nutrirse de idéntico compromiso con la escritura misma, y no de preconcepciones sobre lo que debe parecer para que se le califique de ciencia”.

Resalto una precaución más con respecto a la publicación de los resultados de la investigación: ésta debe ser en todas las lenguas posibles. Si se limita a publicar en inglés siguiendo la ley de los mercados, en poco tiempo las demás lenguas sólo servirán para uso doméstico y perderán su capacidad de ser lenguas de ciencia. Evidentemente no se trata de oponerse a la publicación en inglés, esta batalla estaría perdida desde el inicio, pero el inglés no es suficiente para pensar el mundo. El objetivo de la PHC es promover el uso de las lenguas propias para reforzar el diálogo con las demás lenguas.

\section{Reproducción}

La reproducción es una categoría de las CCC que implica reproducir y generalizar los hallazgos. La replicabilidad tiene que ver con recetas que permiten repetir rutas para conseguir los mismos resultados, son caminos trazados para alcanzar el éxito que se define desde un lugar privilegiado. Pero sabemos que el conocimiento es contextual, por lo que la replicabilidad no puede reducirse a una receta. Lo replicable en la PHC son los conceptos fundadores de la horizontalidad: el conflicto generador, la igualdad discursiva y la autonomía de las miradas.

El problema de "laboratizar" el mundo social y pensar que los resultados científicos pueden replicarse en otros casos, es que la realidad es más compleja de lo que deja ver el laboratorio. Son múltiples los ca- 
sos que sin poner en duda las soluciones que fueron exitosas en otros contextos, no resuelven los nuevos problemas. Como ejemplo, Callon, Lascoumes y Barthe narran el caso de la solución implementada por los científicos para combatir la contaminación radioactiva en el condado de Cumbria en Inglaterra, a raíz de la catástrofe de Chernóbil. Anteriores resultados habían demostrado que aislar el ganado por tres semanas y alimentarlo con bentonita era suficiente para normalizar la situación. Los expertos recomendaron desintoxicar los rebaños de Cumbria de la misma manera. Sin embargo, la propuesta fracasó ya que el experimento en laboratorio no había tomado en cuenta que la tierra era distinta y que los borregos estaban acostumbrados al libre pastoreo. Los pastores no fueron consultados a pesar de que sabían mejor las condiciones del desastre radioactivo en su región. Tras el fracaso de la desintoxicación de los borregos, los campesinos señalaron irónicamente que el error de los investigadores es que piensan equivocadamente que "el campo es el campo y un borrego es un borrego" (Callon, Lascoumes y Barthe 2011, 93).

No hay un solo modo de organizar la experiencia como tampoco hay una sola forma de organizar la trasmisión del conocimiento. La tautología en las ciencias sociales como en el campo con los borregos, cuando no considera las voces de todos, no funciona. También en la reproducción de la PHC debe existir una apertura para escuchar el aporte de lo que cada uno sabe. Esta necesaria flexibilidad y contenido no premeditado para producir algo nuevo, cuenta necesariamente con lo que David Bak-Geller llama la improvisación. En su planteamiento, Bak-Geller distingue tres recompensas de la improvisación en el ámbito social: a) adecuación al lugar y ambiente particular que permite la adaptación práctica a las circunstancias específicas; b) valor de la espontaneidad sobre la rigidez como criterio de autenticidad frente a la inflexibilidad que reduce las opciones del saber; y c) satisfacción por la demostración del dominio de una capacidad o habilidad. La improvisación, de acuerdo con el autor, es un concepto "que nos permite revisar problemas teóricos con una nueva perspectiva y delimitar más precisamente preguntas actuales sobre el ámbito político" (Bak-Geller 2018, 194). En este sentido 
la reproducción no puede generalizarse y replicarse igual bajo condiciones distintas, debe ser flexible y contextualizada, y tener espacio para la improvisación.

El principio de la PHC es la complementariedad en la producción de nuevo conocimiento y por lo tanto reproducirlo significa que se replica en muchas direcciones, y que cada vez que se suman nuevas voces, se pone en práctica el conflicto fundador, la igualdad discursiva y la autonomía de las miradas. Supone el diálogo entre los lenguajes y los contextos, y en su mejor sentido implica improvisar. 


\section{Transformar}

Al llegar a este lugar, el lector habrá recorrido nuestra propuesta que supone que para investigar es imperioso que no domine el propio punto de vista de un solo investigador. Construir las categorías en el encuentro con el otro y discutir el objeto de estudio con el par investigador, así como su participación durante todo el proceso, convocan a un trabajo colectivo. Ahora bien, entendemos que llega un momento en el que tenemos que preguntarnos sobre la verificación de lo que hacemos. En nuestro caso, la legitimidad de nuestro trabajo de investigación "no va a estar dada por la verificación en el sentido positivista tradicional, sino por una intersubjetividad, por la manera en que distintos sectores de una sociedad se sienten representados o no, o pueden desafiar esos textos" (García Canclini cit. en Greeley 2018, 220). Los involucrados en la investigación validarán los procesos y los resultados a partir de los tres conceptos fundadores (conflicto generador, igualdad discursiva y autonomía de las voces), se demandará si hubo nuevo conocimiento y si las relaciones entre las personas se transformaron.

Las formas con las que se valida la PHC no son las mismas con las que se valida el conocimiento de las CCC. Las técnicas de investigación convencionales que se someten a los controles discursivos hegemónicos como si fueran la única vía de generar conocimiento están más interesadas en legitimarse que en enfrentar problemas sociales. De esta manera es claro observar ciertos objetos de investigación repetirse mientras otros no aparecen en las instituciones que se dedican a promover la investigación. La investigación que se evalúa a partir de las disciplinas científicas establecidas con sus rituales propios de verificación crea re- 
gularidades en el proceso investigativo, que terminan por producir un tipo de investigación y un tipo de resultados redundantes.

La PHC construye un espacio de trabajo que genera dos resultados: 1) conocimiento nuevo a partir de múltiples voces en diálogo y 2) escucha equitativa que instaura nuevas relaciones entre las personas. La verificación tiene por lo tanto relación con ambos objetivos: los epistemológicos y los políticos. Es una tarea imposible diferenciar del todo estos planos íntimamente relacionados en la investigación, pero con fines expositivos hablaré por separado de ellos para identificar las formas en que se reconocen los resultados de los métodos horizontales a diferencia de los de la CCC, que en un principio pueden parecer inocentes e intenten presentarse como simples instrumentos de evaluación. Sin embargo, para garantizar la cientificidad se observan ciertas trampas que tienen consecuencias epistemológicas y políticas que la PHC enfrenta con otros artefactos.

\section{Trampas epistemológicas}

La metodología de la CCC propone reglas de producción de verdad que establecen una relación entre la evidencia empírica y la construcción de conocimiento. Pero si pensamos que la verdad existe siempre en un contexto y que su garantía no es universal, sino que ha sido desplazada históricamente desde las antiguas pruebas proféticas y luego empíricas que produjeron distintos tipos de verdad, podemos constatar que sus modos de alcanzarla son siempre inestables. Creemos que no es cuestión de enfocar nuestra atención en la verdad, ni siquiera en las múltiples verdades posibles.

En este sentido, Foucault $(1996,155)$ nos inspira a no inclinarnos por alcanzar la verdad que responde a las reglas de producción hegemónicas, sino en todo caso "a vencerla", y más bien nos alienta a encontrar formas diversas de explicar el mundo. Tampoco buscamos verificar si un investigador cumple con las reglas de la CCC y puede reproducirlas, sino que nos interesa la producción del conocimiento realizado entre muchas voces que nos ayuden a responder a las preguntas sociales que nos afligen. 
El nuevo conocimiento de la PHC será tal porque construido entre los investigadores pares, tendrá la ocasión de escapar a los controles propios de una cultura científica cuyos criterios uniformes son obstáculos para la creatividad que genera el tercer texto que perseguimos. No se verificará lo que ha respondido el otro con el que se realiza la investigación sino se verifica lo que se ha buscado en conjunto, la producción del diálogo y la autonomía de las miradas.

La validación entre pares en el sentido de las instituciones hegemónicas, tampoco aplica en nuestro caso, ya que no serán los investigadores ajenos los que aprobarán individualmente y desde la CCC los resultados que los colectivos de investigadores pares construyen para resolver problemas definidos por dichos grupos. El virólogo Peter Duisberg, científico crítico en el campo del cáncer, señala que el dictamen de pares "está bien para los técnicos, no para la innovación; ya que contribuye a la estabilidad de la mediocridad" (cit. en Epstein 1996, 152). En todo caso, en nuestra perspectiva, los dictaminadores pares que nos interesan, más que calificar la investigación desde los controles disciplinarios, son pares cuando participan en la construcción del nuevo conocimiento y se reconocen en el proceso horizontal. Los pares como los imaginamos, responden a la pregunta ¿cómo responde esta investigación a nuestros problemas sociales?

Cuanto más venerable es un campo de investigación, más difícil se hace aceptar contradicciones evidentes, introducir nuevas prácticas y contribuciones discordantes. Sabemos que las fronteras disciplinarias defienden el tipo de evidencias que le pertenecen a cada disciplina. Después de todo, se piensa muchas veces, un investigador no puede ser experto en todas las áreas y por ello debe ceñirse a ciertos aspectos del fenómeno que su disciplina le ordena y de las formas que le dicta.

Argumentos como este son una manera de evadir la verdad incómoda de que si se quiere comprender verdaderamente un fenómeno social, se deben incluir múltiples voces en diálogo sobre un mismo tema. No es cuestión de discutir con grandes teorías disciplinarias, sino interrogarlas y transformarlas con los aportes de múltiples racionalidades. 


\section{Interdisciplinariedad}

Ayotzinapa es un caso paradigmático de la violencia contra los jóvenes en este país y en América Latina (la limpieza social llevada a cabo en Brasil, en Colombia, en Nicaragua y Guatemala, por mencionar solo algunos). Por eso es de interés verlo como un ejemplo de investigación que exige múltiples formas de construir conocimiento a su respecto. Más allá de la imparcial investigación policíaca que requiere el caso para hacer justicia a las víctimas, hay otra investigación pendiente que impacta a toda la sociedad: ¿qué sucedió y cómo fue posible?

Ayotzinapa es el nombre del poblado donde se encuentra la escuela normal rural "Isidro Burgos", en el estado de Guerrero. El 26 de septiembre del 2014 los jóvenes estudiantes salieron de su escuela normal y unas horas después 6 fueron ejecutados y 43 fueron desaparecidos.

La primera explicación que ofreció el gobierno mexicano al violento hecho fue que era resultado de la complicidad entre grupos del crimen organizado y policías corruptos. Sin embargo las familias de los desaparecidos se hicieron escuchar y la versión oficial gubernamental llamada la "versión histórica", fue enfrentada y desmentida por una combinación de voces; estas son algunas. Por un lado la investigación que realizaron los propios padres y familiares en busca de los jóvenes, acompañados por el Centro Prody y Tlachinollan. El empoderamiento de la comunidad afectada es una forma de construir una epistemología plural que implica una combinación de técnicas, y toma en cuenta la memoria de los testigos. Por otro lado, el grupo interdisciplinario de Expertos Independientes, conformado por juristas, médicos e ingenieros, provenientes de Colombia, Guatemala, Chile, y España, desde sus investigaciones contradicen la "verdad histórica" de la Procuraduría General de la República. La DEA (Administración de Control de Drogas de EUA), proporciona los "chats" por internet que vinculan a los grupos delictivos en Chicago, EUA, con los de Iguala en México. Mientras tanto, la investigación periodística más allá del encubrimiento y de la opacidad del poder, también produjo historias orales y relatos a partir de sus entrevistas. Ver como muestra, "Una historia oral de la infamia" de John Gibler 
y “Ayotzinapa. Horas eternas", de Paula Mónaco Felipe, entre otros libros y múltiples artículos periodísticos. Destaca por su dedicación y compromiso... El video y la fotografía permitió encontrar elementos que no habían sido captados por otros medios como se observa en "Mirar morir" de Témoris Grecko.

Aportaron también los investigadores académicos que investigan los movimientos sociales y las marchas de protesta, aunados a la investigación de los Centros de Derechos Humanos por las violaciones del caso, por ejemplo la tortura a policías. Los abogados de las familias que realizan sus propias investigaciones para defender a las víctimas, y la investigación de arquitectura forense que en museos ha mostrado desde el arte comprometido, la complicidad entre las fuerzas policiales, el ejército y el crimen organizado, son muestras de voces interdisciplinarias y transdisciplinarias que se entretejen en una búsqueda concreta. Recientemente el Primer Tribunal Colegiado del Estado de Tamaulipas ordena una comisión de verdad vinculada a las instancias jurídicas, y el nuevo gobierno en México crea una Comisión de la Verdad del Caso Ayotzinapa, planteando otras voces políticas desde donde alcanzar una explicación a partir de generar conocimiento dialogado. La complejidad de este ignominioso hecho solo es posible explicarla a partir de una investigación con aproximaciones horizontales que tomen en cuenta las voces de la academia, las voces de expertos y las de los implicados (Conversación de la autora con la Dra. Margarita Zires Roldán, miembro del Tribunal Permanente de los Pueblos caso México, febrero de 2019).

La trampa epistemológica consiste en que, al estar frente a otras culturas, somos dominados por las reglas tradicionales de las ciencias sociales, las cuales reproducimos en teorías, métodos y resultados, pero que no nos ayudan en sí mismas a producir nuevo conocimiento.

Aceptar este diagnóstico amenazaría no sólo las narrativas veneradas, sino también las arraigadas disciplinas académicas que las producen. El nuevo conocimiento incorpora múltiples miradas porque reconoce la experiencia teórica de todos los involucrados en los fenómenos 
sociales. Cuando voces muy distintas a las de las ciencias occidentales hablan con las mismas pretensiones de verdad e igualdad, las ciencias sociales con frecuencia no tienen un lugar para acomodarlas, entenderlas y considerarlas en la producción de nuevo conocimiento.

Por eso los resultados de la PHC no se verifican con los mismos métodos, sino que en el camino construyen otras posibilidades. Se abren a las teorías preexistentes y se redefinen en cada contexto. Las categorías no se construyen desde un solo punto de vista, sino se descubren en un proceso en confrontación con la voz de los otros. En el diálogo se traduce, se escucha, se construye una nueva explicación. A diferencia de las estrategias verificativas, esta confrontación no se da al final del proceso, sino durante todo el proceso.

\section{Trampas políticas}

Para las ciencias sociales el hecho de que el ser humano es el sujeto y el objeto de la investigación a la vez es uno de los problemas centrales. La trampa a la que ahora me quiero referir, y que he llamado la trampa política, es creer que hay maneras en que se puede conocer al otro sin su participación. Pensar que hay dos formas de abordar al sujeto social, uno emic con su participación como actor interno y otro etic sin ella, no es suficiente para entender las voces diversas que a la vez participan en múltiples escenarios y que construyen conocimiento desde todos ellos. José Manuel Valenzuela cuestiona la nomenclatura emic/etic por los límites que imponen al trabajo científico: "requerimos problematizar la condición dicotómica entre emic y étic por una perspectiva integradora, una perspectiva emtic donde el adentro y el afuera son asumidos de forma simultánea, alternativa o intermitente y los actores protagonistas se encuentran en las calles y en la academia, en las plazas y en los mundos artísticos, en las revueltas y en las fábricas, en las agrupaciones juveniles y en las redes sociales" (Valenzuela 2015, 43).

Las ciencias sociales, controladas por las instituciones académicas, parten del supuesto de que crear distancia entre investigador e investi- 
gado es un requisito indispensable para conocer científicamente. Consideran que la imparcialidad del investigador está comprometida, ya que él mismo es un ser humano y puede inclinarse a creer que conoce a su "objeto de estudio" intuitivamente. Como respuesta, los manuales de investigación en ciencias sociales están colmados de recetas para lograr la distancia y prevenir la contaminación de la producción científica con la subjetividad del investigador.

Mi propuesta, por el contrario, es que al introducir y aceptar como punto de partida la naturaleza social de los sujetos, donde cada uno se construye frente al otro, nos comprometemos con el postulado de que no se puede conocer al otro sin su propia participación. Desde nuestra perspectiva lo que se puede conocer es sólo lo que el otro desea que sea conocido. Por ello la importancia de construir situaciones horizontales durante la investigación, donde ambas voces se expongan en un contexto discursivo equitativo. En esa confrontación horizontal -cuando los participantes se abren a percibir y a conocer lo que los constituye y que desde un solo lugar no se alcanza a ver-, se alcanza la producción del conocimiento mutuo.

En la práctica investigativa, las estrategias para lograr objetividad son muchas veces trampas en el proceso de creación de conocimiento. Cuando la investigación social se compromete con una alternativa unívoca y cerrada, se produce poco saber nuevo. No es suficiente escuchar y ver al otro, inclusive ser empático; si el encuentro no transforma para entender de otra manera, el conocimiento que pueda producir no deja de ser repetido de lo antes ya creado.

En la práctica investigativa como la planteo, el escrúpulo de la objetividad como forma de asegurar la distancia con el otro desaparece, ya que ambos son investigadores y ambos son el objeto de estudio, o mejor aún, el objeto de estudio es crear entre ambos un conocimiento generador de mejores relaciones en el espacio público. Por lo tanto, la validación adquiere otro sentido que no busca verificar la existencia o la carencia de producción científica -esa está siempre presente-, sino el reto es detectar, describir y argumentar los nuevos aportes de la PHC a la vida social. En la cultura maya, la verificación está relacionada a los 
aportes a una sociedad en un momento determinado, y se presta a la corrección del producto generado: "es una de las prácticas más importantes para la apropiación de los conocimentos culturales, y consiste en supervisar, comprobar y corregir las actividades y acciones pasadas y presentes para garantizar un adecuado aprendizaje" (Yojcom 2013, 117).

La faceta política de la investigación tiene que ver con la horizontalidad del proceso: o bien se distingue formalmente a los "investigadores" y a los "investigados" -estos últimos considerados no aptos para construir conocimiento científico-, o como se propone acá, se esboza un camino hacia el conocimiento mutuo donde ambos son constructores de saber. La trampa política de la investigación impone reglas legítimas de operación que dejan fuera saberes considerados ordinarios, excéntricos o incompatibles con el propio marco de referencia. Pero cuando nos enfrentamos a otras maneras de concebir el mundo podemos entender que la complejidad de los conocimientos sólo puede ser abordada en horizontalidad: ¿cómo vamos a convivir en el mismo espacio público y seguir compartiendo sin escuchar a todos los involucrados? No obstante, cuando las miradas son tan diferentes entre sí, ¿cómo llegar al diálogo productivo y al tercer texto que nos facilite la convivencia? Las pistas están planteadas en este ensayo, las respuestas están por construirse en cada caso.

\section{Otras formas de enseñar y aprender}

Es importante mencionar que la comunidad también me eligió a mí. Para ello, me pidieron que después de presentarme y explicar las razones de mi visita debía tomar yopo dentro de la churuata frente a la comunidad. Esto era un acto importante para ellos, porque así verían mis intenciones a través de mi alma y mi espíritu.

[...]

Llegar como investigadora a proponer un proyecto de investigación frente al cha'no, chan'a y demás miembros de la comunidad, en donde un nieto del abuelo, en piaroa, explica mi presencia ahí, traduce el propósito de mi investigación y se inician las negociaciones: “Si tú haces esto aquí, ¿qué vas a dar a cambio?”. Yo, en el centro junto con el traductor, y alrededor los demás que escuchan y hablan 
en su lengua. [...] Si alguien, después de verme tomar su planta, decide que no puedo hacer el trabajo, significaba un no. Así que en ese preciso momento, el miedo me atravesó; experimenté dudas que iban desde ¿debo hacerlo?, ¿por qué me metí en esto? Pero al mismo tiempo significaba el entrar a la comunidad a partir de lo que ellos consideran sagrado, y decidí que lo haría a pesar del miedo por perder el control durante la toma de la medicina, el enteógeno dimetiltriptamina (DMT), sustancia que se encuentra en la planta.

[...] Comienzo a pensar en cómo describir con pudor y dignidad los actos de otras personas, cómo entrever que las narraciones del otro, con sus silencios, sus huecos y sus vacíos, irrumpen también en la conciencia ética de quien los escucha. Yo. Y en ese momento, la comunidad también me eligió a mí, y así se inicia el viaje por los caminos de la enseñanza hacia la salud.

[...]

Explorar y profundizar en esa complicada versión individual y colectiva de ambos grupos sociales me parecía un objeto de investigación sugestivo, porque ponía en relieve la existencia de otras formas de enseñar y aprender más allá de las escuelas y las aulas, al ser este elemento un pilar dentro de los estudios realizados en el campo de la investigación educativa (Huerta 2017).

Cuando se instaura la igualdad entre todos los participantes del proceso de la investigación emergen riesgos, y el desenlace no se puede predecir desde el comienzo. En la investigación horizontal, como en el espacio público, para poder tejer diferentes y nuevas relaciones entre las personas, se tiene que renunciar a un destino final pronosticado desde el inicio. Lo que constituye un verdadero espacio investigativo, a diferencia del "protocolo de investigación" ordinario que prevé los resultados porque los construye a través de caminos antes transitados, es que el nuevo conocimiento que se construye con el otro es conflictivo, desconocido e imprevisible.

Se impone una reflexión final sobre la validación política de los métodos de investigación: desde mi perspectiva es imprescindible que éstos sean transparentes y sobre todo que tengan como efecto algún tipo de 
provecho para todas las partes. Uno de los efectos de la investigación, no colateral sino esencial, debe ser que a través de la práctica investigativa horizontal se promuevan las miradas autónomas de todos los participantes.

Es necesario prestarse a la verificación de la igualdad discursiva y a la autonomía de las miradas. No se trata de saldar una deuda con el otro visibilizando su conocimiento, porque la autonomía consiste en buscar el conocimiento del otro no para explicarlo desde la voz del investigador, sino para creer en el otro como sujeto intelectual, es decir, sujeto de ciencia. La igualdad para la construcción dialógica del conocimiento sólo existe en su verificación perseverante, y se opone a la búsqueda de las verdades invisibles que los investigadores que no son horizontales pretenden encontrar ocultos bajo capas de velos oscuros.

De los criterios metodológicos de la PHC es central la construcción dialógica de los saberes y no la duplicación del conocimiento. Querer hacer algo nuevo empieza por querer decirlo porque toda acción está atravesada por el lenguaje. Validar la PHC es descubrir el "yo digo" o mejor el ne kenem + reitimait+ yeika, "como yo lo entiendo", de los múltiples investigadores pares. Más que un método en el sentido positivista del mismo, nos hemos inclinado por la definición de algunos criterios metodológicos horizontales y abiertos, cuyo contenido será un problema que la investigación debe resolver a cada paso y en cada caso.

Todo lo anterior nos conduce a reconocer lo erróneo del intento de descubrir una metodología "buena para toda ocasión". Nuestra responsabilidad en la PHC es sacudirnos las reglas impuestas por la academia occidental que se proponen como las vías naturales al conocimiento, y confrontar las prácticas metodológicas que no consideran en igualdad a todas las voces que poblamos el espacio público. El proceso de la PHC termina en la transformación, no en la verificación.

¿Cómo puede la investigación responder a las preguntas sociales que más nos preocupan y a la vez transformar el estado de las cosas para encontrar mejores formas de vivir juntos? La esperanza está en el hecho de que, como señala Freire $(1997,28)$, "no somos seres de adaptación sino de transformación". Contra la verificación que subordina los saberes no académicos como suele suceder convencionalmente en las inves- 
tigaciones que no son horizontales, está nuestra posibilidad de transformar aquello que de manera artificial ha sido establecido como único legítimo. Se precisa encontrar otras señales para validar la PHC que no sean la teoría estándar, el papel de las hipótesis previas a la investigación misma, el dato empírico ni la corroboración de la operacionalización de los conceptos. Las nuevas realidades históricamente determinadas se transforman e implican la necesidad de conceptos también "históricamente determinados", construidos en interacción entre los sujetos y sus teorías. En nuestra propuesta, más cercana al método concreto-abstracto-concreto, nos inclinamos por las preguntas sociales que nos aquejan, al aporte de las teorías acumuladas por los sujetos involucrados y a las transformaciones del propio objeto de investigación.

El punto de llegada es el tercer texto y no el dato. El dato empírico es importante para la CCC porque permite verificar la hipótesis y depende de los conceptos utilizados y del tipo de interacción entre investigador e investigado. De esta manera, De la Garza advierte: "El dato depende siempre de los conceptos utilizados pero también de las interacciones entre el investigador y lo investigado, y de los sentidos que el primero suscita en el segundo. Es decir, es imposible que exista un dato puro para verificar y por lo tanto queda en entredicho el significado positivista de las verificaciones" (De la Garza y Leyva 2012, 239).

En la PHC, la transformación actúa en tres momentos del proceso:

1. Reconocer las fronteras y sus conflictos. El acercamiento al otro es tenso, de fondo no es pacífico porque implica que el primer paso es deconstruirse a sí mismo como legítimo investigador constructor de conocimiento, para poder deconstruir a los considerados por la CCC como ilegítimos investigadores. El proceso no es tranquilo, implica enfrentar el conflicto generador y reconocer que los logos de los otros entran en conflicto con el nuestro. La coexistencia de principios occidentales con otras causalidades choca con la ciencia moderna que ve irreconciliable todo lo que se nombra y se piensa de otra manera. Por ejemplo, enfrentarnos con el conocimiento wixárika de la 
existencia de 5 puntos cardinales en lugar de los 4 que en occidente se consideran universales, muestra que también el lugar donde nos encontramos parados es central y cuenta como el punto de partida para los otros 4; quizás cuestionarnos con los wixaritari si la palabra "geografía" en español es una palabra sagrada, nos permita entender que el derecho a la tierra es el derecho a la vida, o escuchar que los sabios indígenas impugnen un concepto central a la filosofía occidental: la "felicidad", porque "nosotros no tenemos palabra tan exagerada". Sus razones son distintas, tenemos la opción de desecharlas y catalogarlas como mitos primitivos y símbolos de su cultura, o bien reconocer que nuestras razones también obedecen a un contexto, al de la modernidad, las máquinas y las CCC que cambiaron nuestra relación con la naturaleza y con las personas.

2. Borrar las fronteras que etiquetan, invisibilizan y jerarquizan. Cuando los binomios dominan nuestro pensamiento para definir el mundo entre los homólogos y los heterogéneos, entre lo similar y lo diferente, lo que hacemos es sacrificar a unos para afirmarnos como investigadores científicos legítimos. Pero sólo si borramos los límites y nos ponemos en pausa, en identidad evanescente como señala Echeverría, para conocer al otro, podemos juntos producir algo nuevo más allá de las disciplinas consagradas. La transformación en este nivel debe desmitificar las verdades sobre las que se sostiene la CCC. Para borrar las fronteras que nos limitan en el conocimiento social, se requiere de una acción que tome en cuenta las trampas epistemológica, práctica y política para generar relaciones diferentes entre las personas y sus saberes.

3. Construir un tercer texto. No se trata de llegar a una sola respuesta, sino a exponer la complejidad de los hechos sociales vistos desde ángulos diferentes. El tercer texto es la organización de los fragmentos discursivos de los involucrados en la investigación, que permitan que nuestras categorías se transformen de tal manera que hablen por todos. 
Para comprender las interconexiones necesarias para vivir mejor juntos, es deseable empezar por ver cómo los otros deconstruyen su ilegitimidad, cuáles son sus propios procesos para afirmarse como legítimos y diferentes. No necesitan que nadie les dé voz o les ayude a construir su propia historia, ya la tienen los wixaritari en su yeiyari. O como se expresa en ñuu savi,

es hablar de otra historia, la no contada, la no escrita, pero que se encuentra en la sangre, es tan antigua que se tatuó en las piedras y en los códices, con los pinceles de los primeros escritores de este hermoso y antiguo pueblo. Esta historia se niega a desaparecer, permanece en lo profundo de la memoria, se encuentra en el camino de la milpa, en la grandiosidad de las montañas que nos hablan de nuestros ancestros (Sánchez cit. en Bonilla 2015).

Lo que desean las comunidades se puede realizar en el tercer texto, es decir, activar una historia que sea parte de "nuestra" historia, donde la razón de todos se reconozca en las historias que se vinculan unas con otras.

La transformación que incluye las múltiples razones de los sujetos investigadores pares, a diferencia de la validación de la CCC, se presenta como una perspectiva abierta a la investigación contextualizada de una realidad siempre en movimiento y reconstrucción permanente. No son los datos acumulados los que podrán transformar nuestro conocimiento, nuestros entornos sociales y las relaciones entre las personas. La transformación se pretende en los aspectos particulares del proceso de construcción de conocimiento.

Toda PHC significa la verificación de la aplicación de los conceptos fundadores -el conflicto generador, la igualdad discursiva y la autonomía de las voces - a fin de garantizar la posibilidad de replicar el proceso horizontal a partir de las características de cada caso. La verificación y su rectificación en cada situación aportan una contribución en cada nueva práctica investigativa. La validación así incorpora otros nuevos elementos como parte de la dinámica de transformación y nueva producción de conocimiento. 


\section{Epílogo}

Quizás aún quede la siguiente pregunta por responder: ¿quién puede aplicar la PHC a su investigación? Argumentar que la elección tiene que ver con el motivo de la investigación, que los métodos horizontales son idóneos en grupos pequeños e indígenas y que no contribuyen en investigaciones con poblaciones urbanas, o que realizar investigación con impacto social tiene que ver con gustos personales, son las respuestas fáciles. Mi contestación tiene que ver con responder a las preguntas que quedan sin satisfacción con métodos convencionales: ¿cuáles otras heterogeneidades no estamos viendo ni escuchando con los métodos tradicionales de las CCC? ¿Conocemos cómo los distintos espacios sociales, urbanos y no urbanos, premian y castigan la visibilidad de otros desde su propia mirada y en interrelación con nosotros? ¿Qué esperan los unos de los otros? ¿Es suficiente la incidencia de la investigación social académica para resolver los problemas sociales que padecemos? Añado a la lista las preguntas de la investigadora indígena Linda Tuhiway Smith $(2015,297)$ : ¿Por qué piensan ellos que mirándonos a nosotros van a encontrar las respuestas a nuestros problemas? ¿Por qué no se miran a sí mismos?".

Lo que se advierte durante la PHC es que la manera en que hemos sido enseñados a percibir nuestro mundo social no es suficiente, ya que deja fuera el conocimiento de los otros y por lo mismo repite los resultados construidos con métodos convencionales que los excluyen. La PHC postula que toda investigación social debe respetar la experiencia y el conocimiento que tienen todos. Ojalá este libro ayude a aclarar lo que entiendo por respeto e inclusión en el contexto de la producción de nuevo conocimiento. 


\section{Bibliografía}

Agüero, José CARLos. 2015. Los rendidos. Sobre el don de perdonar. Perú: Instituto de Estudios Peruanos.

ANDERSON, LORIN. 2015. “¿Cuál es el papel apropiado de la investigación en los programas doctorales en educación?". En La formación de nuevos investigadores educativos, coordinado por María de Ibarrola y Lorin Anderson. México: ANUIES.

ARENDT, HANNAH. 1993. La condición humana. Barcelona: Paidós.

BAJTíN, MIJAÍL. 2003. Estética de la creación verbal. México: Siglo XXI.

внавна, номі. 2003. "El entre-medio de la cultura". En Cuestiones de identidad cultural, Stuart Hall y Paul du Gay. Buenos Aires: Amorrortu.

BAK-GELLER, DAVID. 2018. “Improvisación práctica: una reconsideración de la espontaneidad para la teoría democrática". En Conceptos políticos. Herramientas teóricas y prácticas para el siglo XXI, coordinado por Melissa Amezcua y David Bak-Geller, 171-195. Guadalajara: Universidad de Guadalajara.

BAK-GELLER, SARAH. 2019. "Recetas de cocina, cuerpo y autonomía indígena. El caso coca de Mezcala, Jalisco". Coloquio Internacional "Patrimonios Alimentarios: consensos y tensiones”. México, El Colegio de San Luis-Institut de Recherches pour le Développement.

BARBA, CARLOS. 2007. ¿Reducir la pobreza o construir ciudadanía social para todos? América Latina: regímenes de bienestar en transición al iniciar el siglo XXI. Guadalajara: Universidad de Guadalajara.

BARONNET, BRUNO, Mariana Mora y Richard Stahler-Sholk, coords. 2011. Luchas "muy otras". Zapatismo y autonomía en las comunidades indígenas de Chiapas. México: UAm Xochimilco-CIEsAs-Unach.

Benveniste, ÉmiLe. 1975. Problemas de lingüística general. México: Siglo XXI. 
BONILla, FABIAN. 2015. "La construcción de sentidos de la memoria y del patrimonio cultural en dos museos comunitarios ñuu savi, Oaxaca”. Tesis de doctorado en Ciencias Sociales, UAM Xochimilco.

bourdieu, pierre. 2013. La Miseria del Mundo. Ciudad de México: Fondo de Cultura Económica.

BUCK-MORSS, SUSAN. 2013. Hegel, Haití y la Historia Universal. México: Fondo de Cultura Económica.

CAllon, Michelle, Pierre Lascoumes y Yannick Barthe. 2011. Acting in an Uncertain World. An Essay on Technical Democracy. Estados Unidos: The MIT Press.

CASTILlejo, Alejandro. 2016. "Violencia, inasibilidad y la legibilidad del pasado: una crítica a la operación archivística”. En (In)disciplinar la investigación. Archivo, trabajo de campo y escritura, coordinado por Frida Gorbach y Mario Rufer, 114-139. México: UAM-Siglo XXI.

COOK-LYNN, ELIZABETH. 2008. "History, Myth, and Identity in The New Indian Story". En Handbook of Critical and Indigenous Methodologies, editado por Norman K. Denzin, Yvonna S. Lincoln y Linda Tuhiwai Smit, 329346. Estados Unidos: Sage Publications.

cooper, caren. 2018. Ciencia Ciudadana. Ciudad de México: Secretaría de Cultura-Dirección General de Publicaciones-Grano de Sal.

CORNEJO, INÉs. 2016. Juventud rural y migración mayahablante. Acechar, observar e indagar sobre una temática emergente. Ciudad de México: UAM. COROna, SARAh, coord. 2016. Diálogos educativos dentro y fuera del aula. Guadalajara: Universidad de Guadalajara.

CORONA, SARAH et al. 2007. Entre voces... Fragmentos de educación entre-cultural. Guadalajara: Universidad de Guadalajara.

Corona, SARAh y Olaf Kaltmeier. 2012. En diálogo. Métodos horizontales en Ciencias Sociales y Culturales. Barcelona: Gedisa.

Cuevas, Julio y Myriam Rebeca Pérez-Daniel. 2013. "Conocimientos Locales y Universales en ciencias naturales y matemáticas: reflexiones sobre su negociación desde el currículo y los materiales educativos". REDHES v, núm. 10.

DE la GARZA, enRIQUe y Gustavo Leyva, eds. 2012. Tratado de metodología de las ciencias sociales: perspectivas actuales. México: Fondo de Cultura Económica-UAM. 
DE LA PEZA, CARMEN. 2012. "Consideraciones sobre la traducción en la investigación horizontal”. En En diálogo. Métodos horizontales en Ciencias Sociales y Culturales, coordinado por Sarah Corona y Olaf Kaltmeier, 185-208. Barcelona: Gedisa.

De sousa, Boaventura. 2010. Descolonizar el saber. Reinventar el poder. Montevideo: Trilce.

DE SOUSA, BoAventura. 2017. Democracia y transformación social. Ciudad de México: Siglo XxI.

ECHEVERRíA, BOlíVAR. 1997. Las ilusiones de la modernidad. México: unAMEl equilibrista.

epstein, steven. 1996. Impure Science. aids, Activism, and the Politics of Knowledge. Berkeley: University of California Press. FOUCAULT, MICHEL. 1996. La verdad y las formas jurídicas. Barcelona: Gedisa. FREIRE, Paulo. 1970. Pedagogía del oprimido. Madrid: Siglo XXI. FREIRE, PAUlo. 1997. A la sombra de este árbol. Barcelona: El Roure. GARCÍA, NÉSTOR. 1990. Culturas Híbridas. Estrategias para entrar y salir de la modernidad. Ciudad de México: Grijalbo.

GEERTZ, CLIFFORD. 1997. El antropólogo como autor. Barcelona: Paidós. GIEBELER, CORNelia y Marina Meneses. 2012. "Dar y recibir en la investigación. Reflexiones por espacios trans, inter e intraculturales en la investigación". En Horizontalidad, diálogo y reciprocidad en los métodos de investigación social y cultural, coordinado por Rebeca Pérez y Stefano Sartorello. Chiapas: Cenejus-Cocytech-Unach.

GREELEY, ROBIN ADÈLE. 2018. La interculturalidad y sus imaginarios: Conversaciones con Néstor García Canclini. Barcelona: Gedisa.

GRIMSON, ALEJANDRO. 2011. Los límites de la cultura. Crítica de las teorías de la identidad. Argentina: Siglo xxI.

Grossberg, LAWRENCE. 2009. "El corazón de los estudios culturales: Contextualidad, construccionismo y complejidad". Tabula Rasa, núm. 10. HUERTA, MYRNA CAROLINA. 2017. “Mänä äjätjü/ Los caminos hacia la salud: Proceso(s) de transmisión y apropiación de saberes y conocimientos en salud". Tesis de doctorado en Educación, Universidad de Guadalajara. KAPUŚCIŃSKI, RYSZARD. 2009. Encuentro con el Otro. México: Anagrama. 
LANDER, EDGARDO. 2004. "Eurocentrismo, saberes modernos y naturalización del orden global del capital”. En Modernidades coloniales, coordinado por Saurabh Dube, Ishita Benerjee Dube y Walter Mingolo, 259-283. México: El Colegio de México.

LÉVI-STRAuSS, Claude. 1992. Tristes trópicos. Barcelona: Paidós.

MATA, MARÍA CRISTINA. 1982. “¿La alternativa legalizada? Una lectura precavida del Informe Mac Bride”. En Por una información libre y liberadora. Lima: Celadec.

MARTín, Jesús. 1980. "Retos a la investigación de comunicación en América Latina". Comunicación y Cultura, núm. 9.

MARTín, JEsús y Sarah Corona. 2017. Ver con los otros. Comunicación Intercultural. México: Fondo de Cultura Económica.

MARTÍNEZ, SANDRA NADEZHDA. 2009. "La etnicidad en el discurso político de la organización nación P'urhépecha”. Tesis de maestría en Ciencias Sociales, Universidad de Guadalajara.

MAtTelart, Michèle y Mabel Piccini. 1973. "La prensa burguesa, ¿no será más que un tigre de papel? Los medios de comunicación de la oposición durante la crisis de octubre de 1972". Cuadernos de la Realidad Nacional 16: 250-263.

mattelart, armand, Mabel Piccini y Michèle Mattelart. 1970. "Los medios de comunicación de masas. La ideología de la prensa liberal en Chile”. Cuadernos de la Realidad Nacional.

MIER, RAYMUNDO. 2010. "Los métodos cualitativos en la investigación social: hacia un saber sin garantías”. En El arte de investigar, coordinado por Pablo Mejía, José Manuel Juárez y Sonia Comboni, 249-264. México: UAM Xochimilco.

MIZUNO, NORIKO. 2012. "Los procesos de negociación cultural en los trajes bordados huicholes. La comunicación en San Andrés Cohamiata”. Tesis de maestría en Comunicación, Universidad de Guadalajara.

mouffe, Chantal. 1999. El retorno de lo político. Comunidad, ciudadanía, pluralismo, democracia radical. Madrid: Paidós.

Nogueira, BeAtriz. 2019. "Los cuerpos son espacios de conocimiento. Partería en Presidio de los Reyes". Tesis de doctorado en Ciencias Sociales, Universidad de Guadalajara. 
oliveira, ARistinete. 2013. La filosofía Latinoamericana como Política Cultural. Un diálogo con Richard Rorty y Raúl Fornet-Betancourt. Colombia: Universidad Santo Tomás.

parameswaran, RadHika. 2008. "Reading the Visual, Tracking the Global. Postcolonial Feminist Methodology and Chameleon Codes of Resistance". En Handbook of Critical and Indigenous Methodologies, editado por Norman K. Denzin, Yvonna. S. Lincoln y Linda Tuhiwai Smith, 407-428. Estados Unidos: Sage Publications.

PÉREZ, DANIELA. 2019. "Educadores patrimoniales en museos jaliscienses". Tesis de doctorado en Educación, Universidad de Guadalajara.

PÉREZ-DANIEL, REBECA. 2012. "Entre voces: hacia la configuración de una metodología para el estudio y trato de lo intercultural". En Horizontalidad, diálogo y reciprocidad en los métodos de investigación social y cultural, coordinado por Rebeca Pérez-Daniel y Stefano Sartorello. México: Unach-Cenejus-Universidad Autónoma de San Luis Potosí-Cocytech. PÉREZ-DANIEL, REBECA y Sarah Corona. 2007. Los wixaritari viajan a la ciudad. Guía y memoria de un viaje de San Miguel Huaixtita a Guadalajara/ Wiixaaritaari kiekaritsie mepikiinetiwe. Ke mitiuyaani hawai xika reuyaaní metá miraa'eeriwaáni. México: Cenejus-Unach-Universidad de Guadalajara-ECICH.

PUlido, yAZBETH. 2017. "La comunicación intercultural en la atención de la indígena embarazada en los Hospitales Civiles de Guadalajara". Tesis de doctorado en Ciencias Sociales, Universidad de Guadalajara.

RAMA, ÁNGEL. 2009. La ciudad letrada. Madrid: Fineo.

RANÇIÈRe, JACQUeS. 1998. Aux bords du politique. París: La Fabrique.

RANÇIÈRE, JACQUES. 2004. Le maître ignorant. París: Fayard.

RANÇIÈRE, JACQUES. 2007. El maestro ignorante. Cinco lecciones sobre la emancipación intelectual. Buenos Aires: Zorzal.

RAPPAPORT, JOANNE. 2017. "'El cobarde no hace historia': Orlando Fals Borda y la doble historia de la Costa del Caribe". En Precariedades, exclusiones y emergencias. Necropolítica y sociedad civil en América Latina, compilado por Mabel Moraña y José Manuel Valenzuela, 175-198 . México: UAM-Gedisa. RESTREPO, EDUARDO. 2016. Etnografía: alcances, técnicas y éticas. Bogotá: Pontificia Universidad Javeriana. 
RIAÑO, YVONNE. 2012. "La producción de conocimiento como 'minga'. Co-determinación y reciprocidad en la investigación con mujeres migrantes de América Latina, Medio oriente y Europa suroriental en Suiza”. En En diálogo. Métodos horizontales en Ciencias Sociales y Culturales, coordinado por Sarah Corona y Olaf Kaltmeier. Barcelona: Gedisa.

RIAÑO, PILAR, coord. 2013. Recordar y narrar el conflicto. Herramientas para reconstruir memoria histórica. Bogotá: Centro Nacional de Memoria Histórica-University of British Columbia.

RIBEIRO, LAIR y Martha Teresita de Barbieri. 1973. "La mujer obrera chilena". Cuadernos de la Realidad Nacional, núm. 16: 167-201.

RUFER, MARIO. 2012a. "El habla, la escucha y la escritura. Subalternidad y horizontalidad desde la crítica poscolonial". En En diálogo. Métodos horizontales en Ciencias Sociales y Culturales, coordinado por Sarah Corona y Olaf Kaltmeier. Barcelona: Gedisa.

RUfer, MARIO. 2012b. Nación y diferencia. Procesos de identificación y formaciones de otredad en contextos poscoloniales. Ciudad de México: Itaca.

RUFER, MARIO. 2012c. Nosotros y los Otros en la comunicación intercultural. Estados Unidos: IAICS, vol. 21-1.

RUFER, MARIO. 2016. "El archivo: de la metáfora extractiva a la ruptura poscolonial". En (In)disciplinar la investigación. Archivo, trabajo de campo y escritura, coordinado por Frida Gorbach y Mario Rufer, 114-139. Ciudad de México: UAM-Siglo XXI.

RUIZ-PÉREZ, RAFAel, Diego Marcos-Cartagena y Emilio Delgado. 2014. "La autoría científica en las áreas de ciencia y teconología: políticas internacionales y prácticas nacionales en las revistas científicas española”. Revista Española de Documentación Científica 2, núm. 37.

SAlVADOR, Agustín y Sarah Corona. 2018. Nuestro libro de la memoria y la escritura. Guadalajara: Universidad de Guadalajara.

SARTORI, GIOVANNi. 2001. La sociedad multiétnica. Pluralismo, multiculturalismo y extranjeros. Madrid: Taurus.

SASSEn, SASKIA. 2010. Territorio, autoridad y derechos. De los ensamblajes medievales a los ensamblajes globales. Buenos Aires: Katz Editores. SASSEN, SASKIA. 2015. Expulsiones. Brutalidad y Complejidad de la Economía Global. Buenos Aires: Katz Editores. 
SENNETT, RICHARD. 2003. El respeto. Sobre la dignidad del hombre en un mundo desigual. Barcelona: Anagrama.

Shavelson, Richard J., D. C. Phillips, Lisa Towne y Michael J. Feuer. 2003. "On the Science of Education Design Studies". Educational Researcher 32, núm. 1.

SMIth, LINDA tUhiwai. 2015. A descolonizar las metodologías. Investigación y pueblos indigenas. Santiago de Chile: LOM.

Subirats, EdUARDo. 1994. El continente vacío. México: Siglo Xxi.

TAtyisavi, KAlu. 2014. Iyo jika Savi. Exilio de la lluvia. Barcelona: Barcelona Digital.

TOURAINE, ALAIN. 2006. "Las condiciones de la comunicación intercultural”. En Multiculturalismo. Desafíos y perspectivas, coordinado por Daniel Gutiérrez Martínez. Ciudad de México: unAM-Siglo xxi-El Colegio de México. VALENZUELA, JOSÉ MANUEL. 2014. Transfronteras: fronteras del mundo y procesos culturales. Tijuana: El Colegio de la Frontera Norte.

valenzuela, José manUel. 2015. El sistema es antinosotros. Cultura, movimientos y resistencias juveniles. México: Gedisa-UAm-El Colegio de la Frontera Norte.

voloshinov, valentín. 1976. El signo ideológico y la filosofía del lenguaje. Buenos Aires: Edición Nueva Visión.

villoro, Luis. 1993. "Aproximaciones a una ética de la cultura". En Ética y Diversidad Cultural, coordinado por León Olivé. México: UnAm-Fondo de Cultura Económica.

villoro, Luis. 2006. Estado Plural, pluralidad de culturas. México: Paidós-UNAM.

YOJCOM, DOMINGO. 2013. La epistemología de la matemática maya. Guatemala: PACE/GIZ-Editorial Maya'Wuj. 


\section{AUTORA}

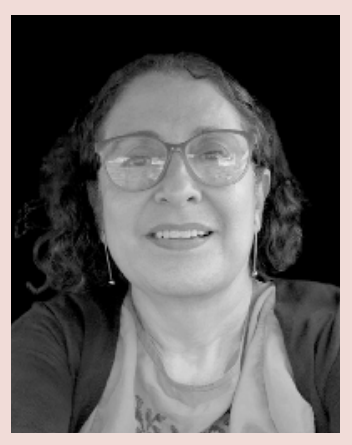

\section{Sarah Corona Berkin}

Es comunicóloga por la Universidad Iberoamericana y doctora en Comunicación por la Universidad de Lovaina. Actualmente es investigadora de la Universidad de Guadalajara y forma parte del Sistema Nacional de Investigadores (nivel III). Heredera de la investigación acción y la investigación participativa latinoamericana, ha realizado trabajo principalmente en tres campos: 1) comunicación educativa, escrita y en imágenes, 2) historia de la fotografía indígena y 3) educación y ciudadanía en los libros de texto. Su experiencia en estos temas la han llevado a proponer métodos dialógicos y horizontales para analizar algunos de los problemas epistemológicos y ético-políticos que enfrentan los diferentes tipos de conocimiento (interdisciplinario, local y tradicional), con el objetivo de producir horizontalmente nuevo conocimiento. Entre las principales distinciones que ha recibido se encuentran: el Premio de la Organización de Estados Iberoamericanos para la Educación y la Cultura, como asesora pedagógica del proyecto Secundaria Intercultural Tatuutsi Maxakwaxi; el Gold Addy Award de la American Advertising Federation, por la investigación intercultural para el calendario wixárika; y el Premio Tenamaztle, por parte del Centro Universitario del Norte. Entre sus libros pueden mencionarse: Entre voces... Fragmentos de educación "entrecultural" (2007), Postales de la diferencia. Fotografías wixáritari de la ciudad (2011) y La asignatura ciudadana en las cuatro grandes reformas del LTG en México entre 1959-2010 (2015). Es directora del Centro Maria Sibylla Merian de Estudios Latinoamericanos Avanzados (CALAS) y coordina el Programa Nacional Estratégico: Educación para la Inclusión (Conacyt-Programa Nacional de Lectura). 


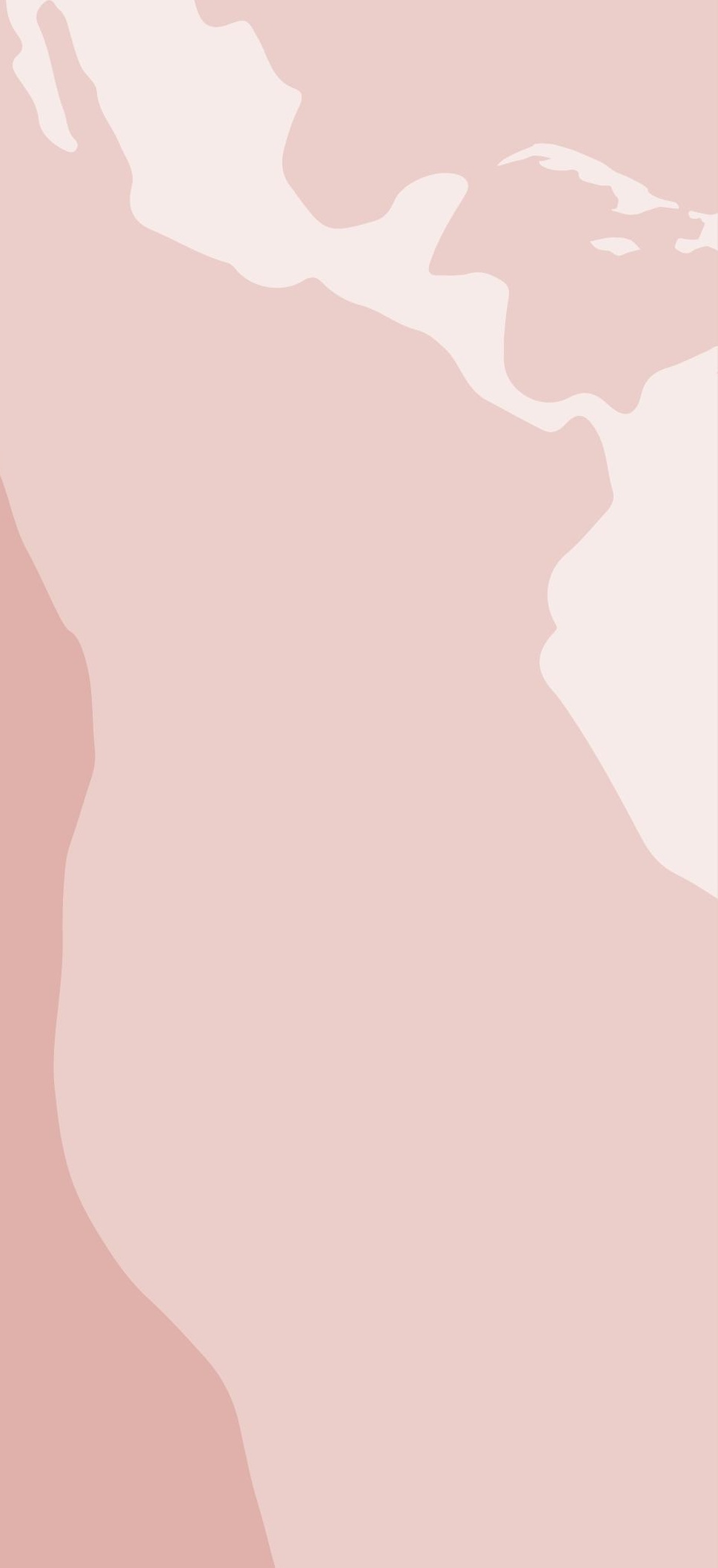




\section{OTROS TÍTULOS DE LA COLECCIÓN}
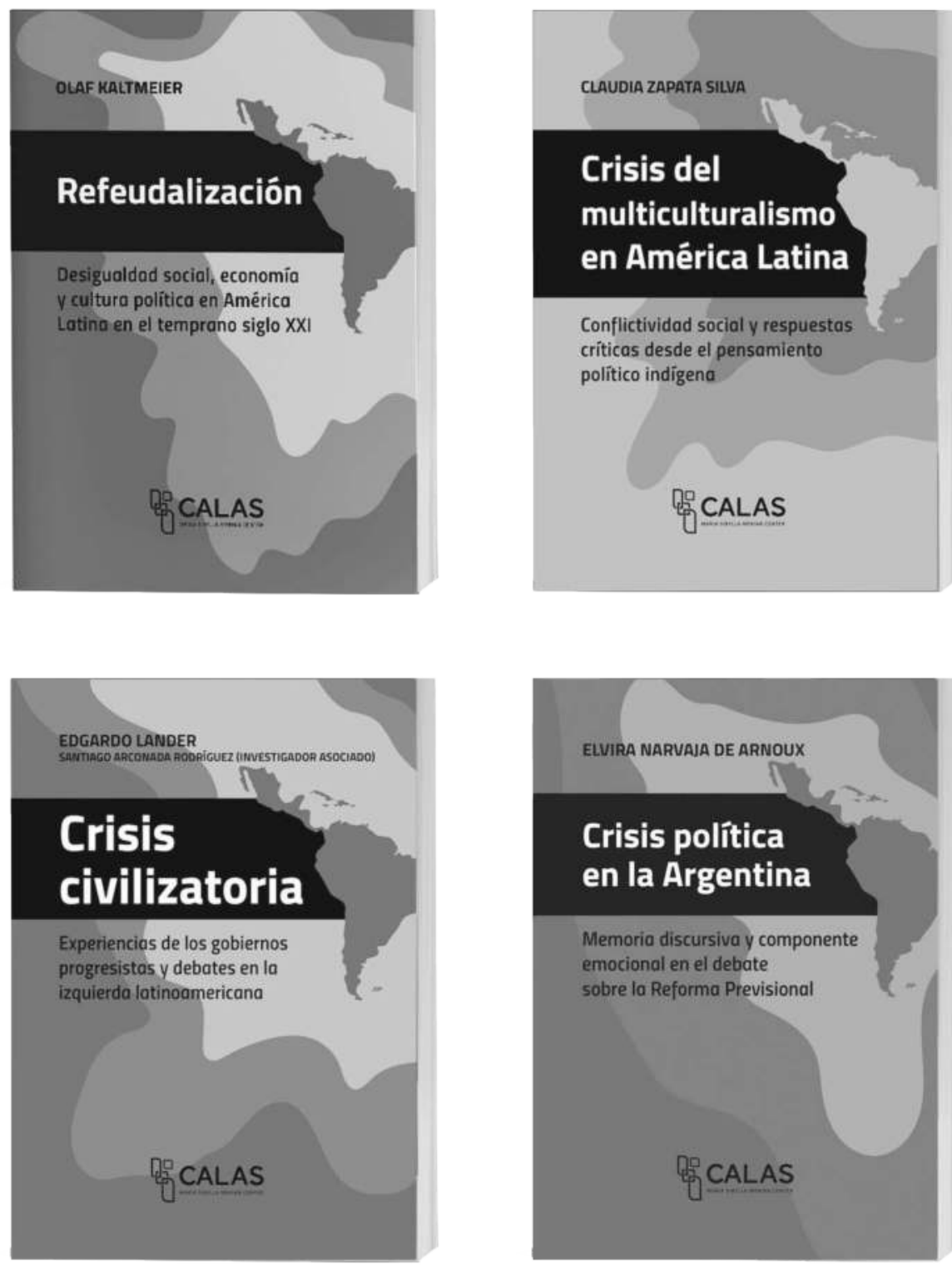


\title{
Producción horizontal del conocimiento
}

\author{
Coordinación editorial \\ Iliana Ávalos González
}

\section{Cuidado editorial}

Mariana Hernández Alvarado

Diseño de la colección

Paola Vázquez Murillo

Pablo Ontiveros

\section{Diagramación \\ Pablo Ontiveros}

